Digitized by the Internet Archive in 2009 with funding from NCSU Libraries 


\section{BEAUTIFUL HOME SURROUNDINGS}

If you would hate that beaty which is akin to the divine in Niture, if you would have around ahout you the songs of the birds, the seent of blossoms, - the content and cheer which they bring - surround yourself with tree and vine and all these shall be yours

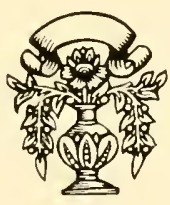

FRAMINGHAM NURSERIES

FRAMINGHAM, MASS.

1921
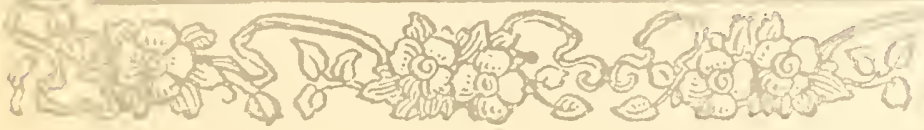



\section{FOREWORD}

TI mblishing this Catulog, it has been our andencor to heighten its practical usefulness by departing from the usual custom among 1 nurserymen of presenting their stock almost entively in the nature of a botanical clasification. Believing that but feor persons coutside of collectors) are interested in, or buy, musery stoct for its scientific significance or value alone, we hawe arranged the following lists in a way that we feed will be of most genuine aid to the great mujomity of plant buyers who looki upon what they buy as IIOME S'ENERY - to be ornamental, or serviecable, or both - but who may need a certain amount of experienced suggestion and guidanee, first in visualizing and finally in accomplishing the results they have in mind.

For this reason we have classified and herewith present our stocl: not botanically but as the layman sEEs it - according to the artistis or utilitarian purpose or purposes for which each varicty is best suited. In the same mamer the general directions for planting with which we have amplified these lists - while essentially incomplete and in no way intended as a technical handling of the subject - will, we belicve, be welcome and of tangible help.

In short, we have attempted to provide a comprehensive and easily comprehended reference book on the beutificution of home surroundings for the arerage American home-lover - to whom it is respectfully dedicated.

We shall mention. ow history but briefly. Established more than twenty years ago by the late $\mathrm{W}$. B. Whittier, this firm has made a practice of groneing only the best quality of mursery stock in the varieties that have proved to be hardiest and most desirable in this rigorons northern climate. though now under different mamagement, we have continued to follow ulom, these lines. Consequently, Framingham Nursery Stock is recognized as the standurd for Ameriea in giving customers " "square deal".

Being of perishuble nuture, our stocli is not guaranted to live. Ite do, however, guarantee it to be alize and healthy at time of shipment. All we ask is that reasonable care be taken of it, in helping it through dry seasons, ete. IIe meet the buyer more than half way in pursuing a policy of giving absolute satisfaction. And such a guarmantee from us is far stronger than that of replacement by a firm of lesser reputation.

\section{Framingham Nurseries \\ FRAMINGHAM \\ MASS.}




\section{The General Purposes of Planting}

Plantings of deeichous and evergreen shrubs or trees on the average of residential premises or estates may be divided into the following sorts:

\section{Foundation Planting}

Sereen Planting

(a) For shutting out unsightly views

(b) For seclusion and privacy

(c) For protcction against wind, otc.
Shade Planting

Individual specimen Plantings

Natural Plantings

Odd Purposes

Plantings to Atract Birds

\section{Foundation Planting}

YINCE bare foundations, sharp angles, and straight lines are the most noticeable - features - or rather, faults - of an unplanted home, we will consider this sul$D$ ject first. The purpose in foundation planting is, naturally, to soften and hide the straight, severe, and often unsightly, lines and angles, to bring a pleasing attraction out of the fundamentally commonplace. To acemplish this is really very simple, and results in vast improvement. But, first, one must hear in mind that it is unadrisable to plant tall growing shruls under windows. The place for them is between windows. Also that uniformity in planting seldom brings the desired soltness or artistry of effect. Following are some suggestive sketches which we hope will be of assistance to the reader in visualizing and earrying out these essential points, and others.

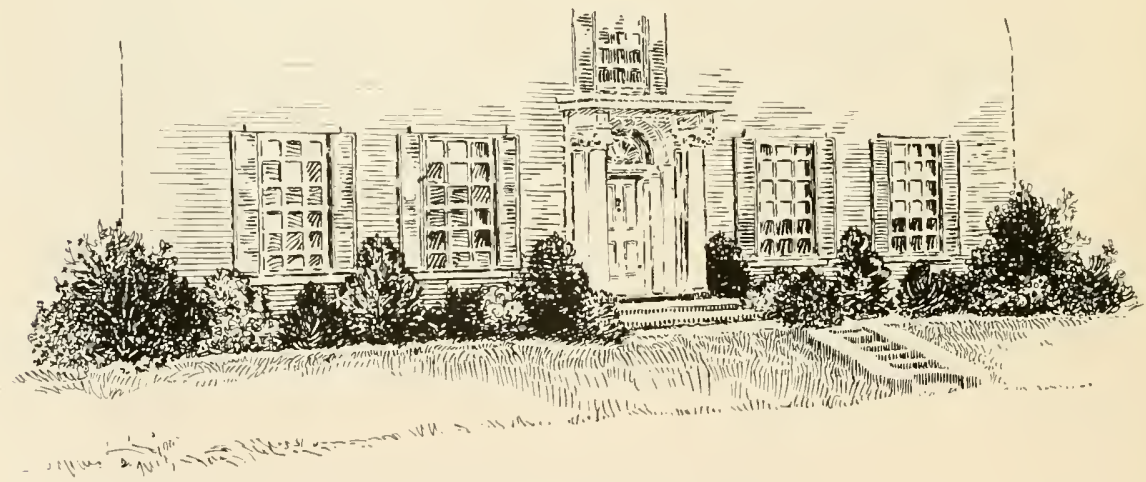

Sketch No. 1

If your window-sills are five feet from the ground (which is aloont the general average of height) set ont shrulss ultimately attaining four feet, but not over five feet in height. In order that this planting shall not be uniform and, eonsequently, monotonors, take advantage of the spaces between windows to plant taller shrubs. Sketeh No. 1 illustrates this point. 
Bnt how is one to determine preeisely what variefies of shruhs atlain certain eventual heights? 'This, of eourse, is an important question. But you will notice that the plants listed as for foundation planting in this eatalog are arranged acoroling to ultimute size lo facilitate their selection in properly attending it.

1 double row of plants always multiplies the beanty and effectiveness of a planting. The best practiee is, wherever possible, to stagger the rows, as illustraled in Sketelo No. 2.

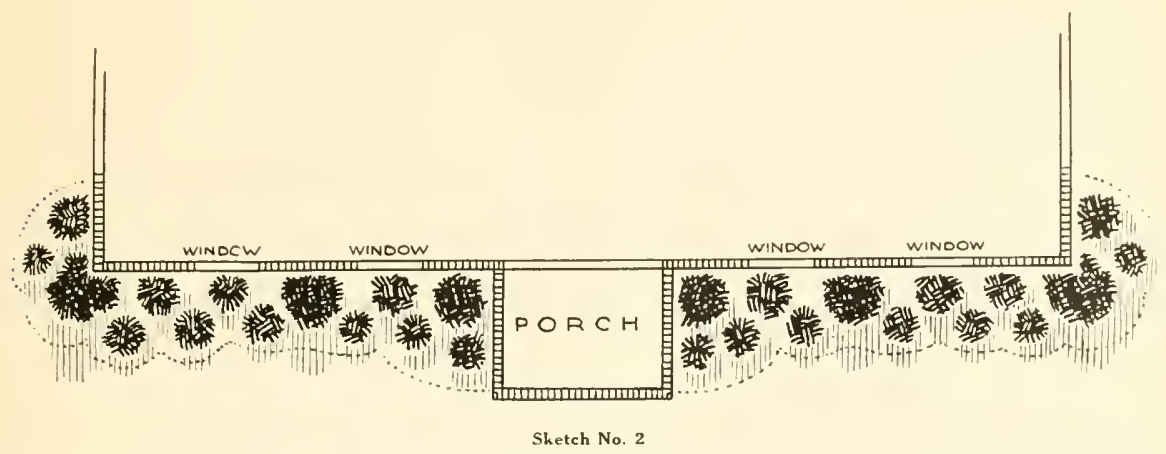

Where the plants are tallest, the beds should be widest. Therefore the ideal plantingplan for a foundation planting such as is suggested in Sketeh No. 1 would be as in sketch No. 3.

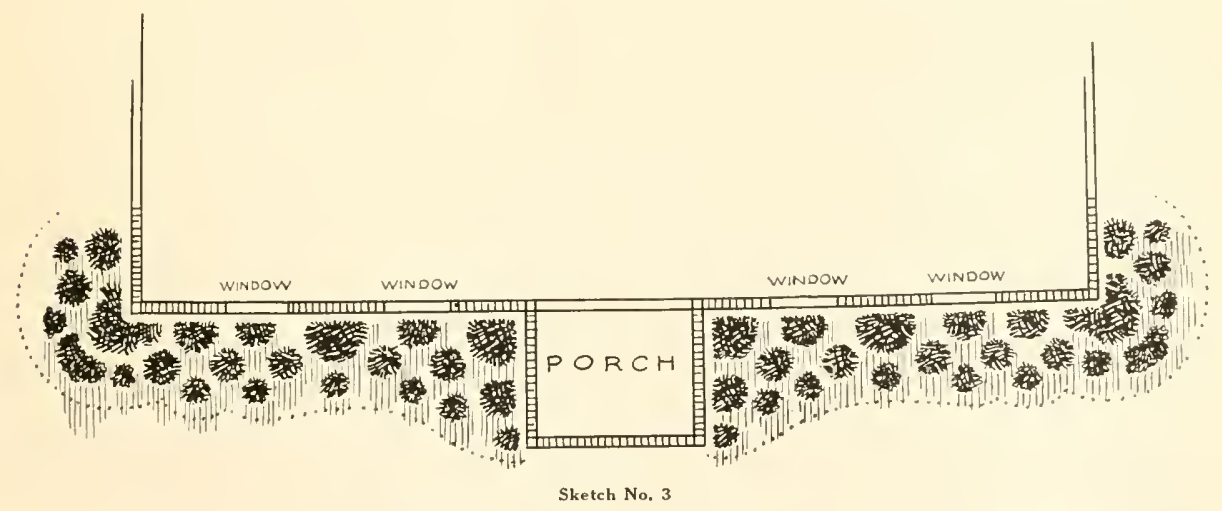

As will be noted, this rosults in a massing of slunbs about the eorners and in the angles hetween house proper and porch - a very rlesirable leature. In reaching this etlect, shrubs which attain an ultimate height of not over five fret shomld be planted three feet apart from center to center; larger shrubs, three and one-luall to four feet apart. 'The langer plants slould be next to honse with smaller plants toward lawn.
“ T H E
$S \mathrm{~T} A N \mathrm{D} A \mathrm{R}$ D
O F
Q U A L I T Y
F O R
A M E R I C A," 
Turning to pages 7 to 11 we find deciduous slumbs suitable for this purpose gromped according to heights, to hloom (or lack of it), and the color of blossoms, and the l, looming

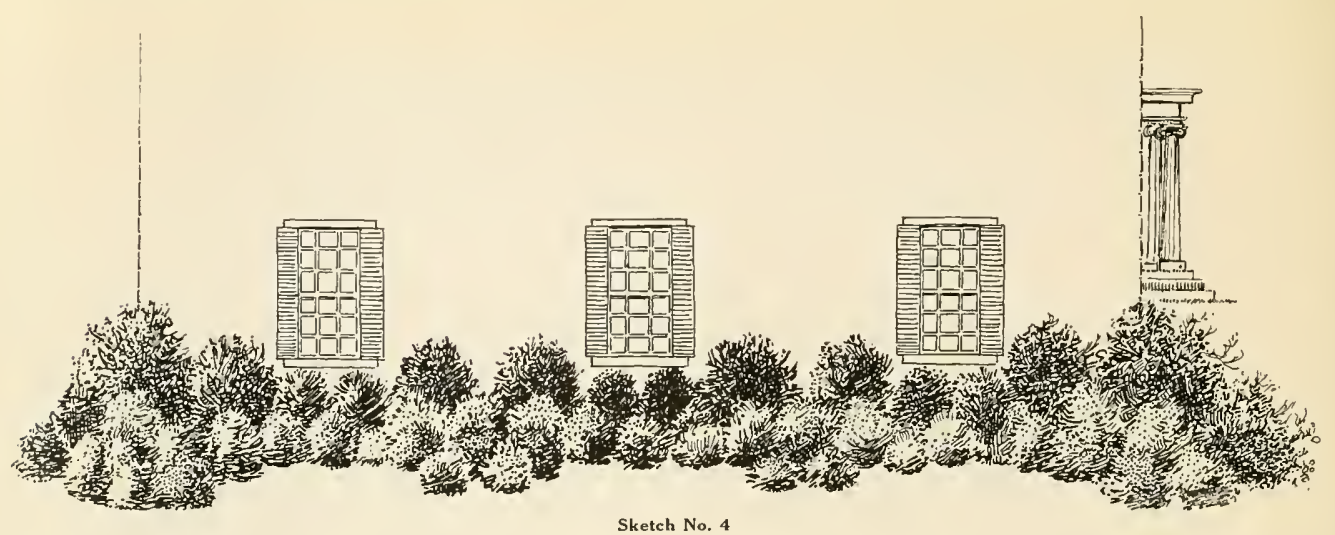

period. Select the colors and blooming periods that you most prefer. But do not select too many kinds. On a border planting of average size (such as the foregoing sketches represent) ten or twelve varieties make a much better showing than do twenty or thirty.

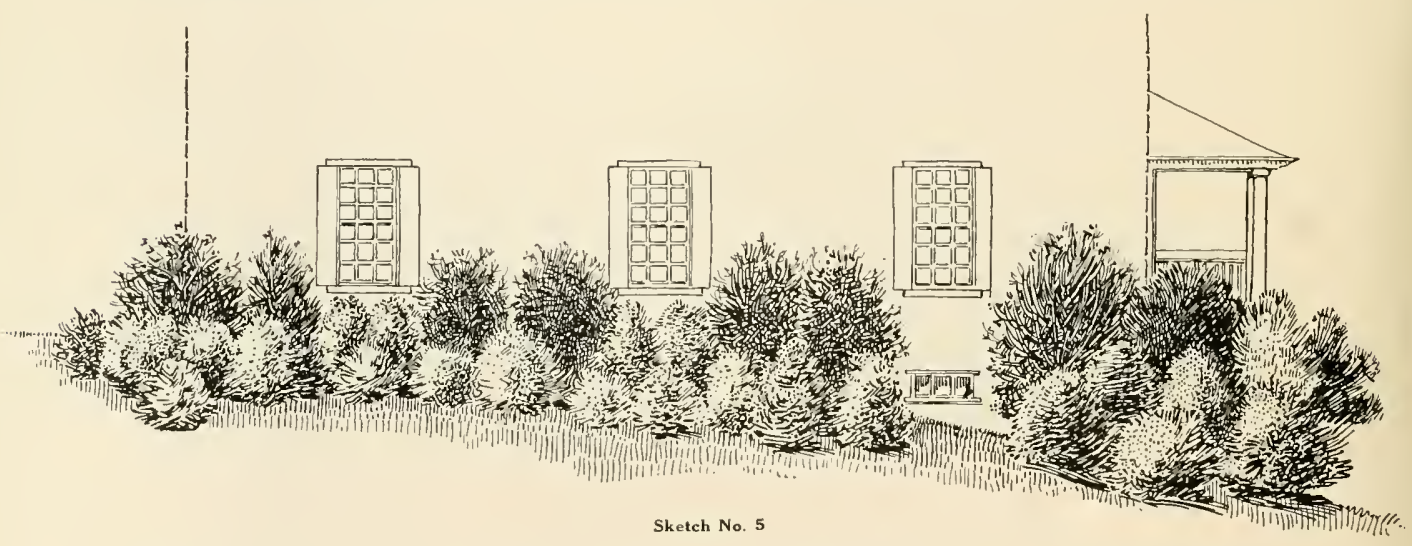

Following the simple rules we have laid down, side of house should be arranged to look about as Sketch No.t.

Of course where the ground slopes away as in Sketch No. 5, taller shruls can be used under windows, leaving spaces as required for coal window, cellar bulkhead, etc.

F R A M I N G H M N U R S E R I E S - F R A M I N G H A M, MA S S. 


\section{Deciduous Flowering and Ornamental Shrubs for Foundation Planting}

$\mathrm{T}$ () faeilitale choice and to permit the buyer to vismalize selection so as to apply the simple fundanental rules for successlul fomblation planting as set forth in the preceding pages, we lawe listed all plants in the present classifieation first, according to nltimate height; second, aceording to the color of flowers or leal and fruit effect; third accoreling lo commont or popular name. The botanical name is always to be found, in italics, loblowing the common name. Varieties marked with daggere (†) atre valuable for seat-shore planling.

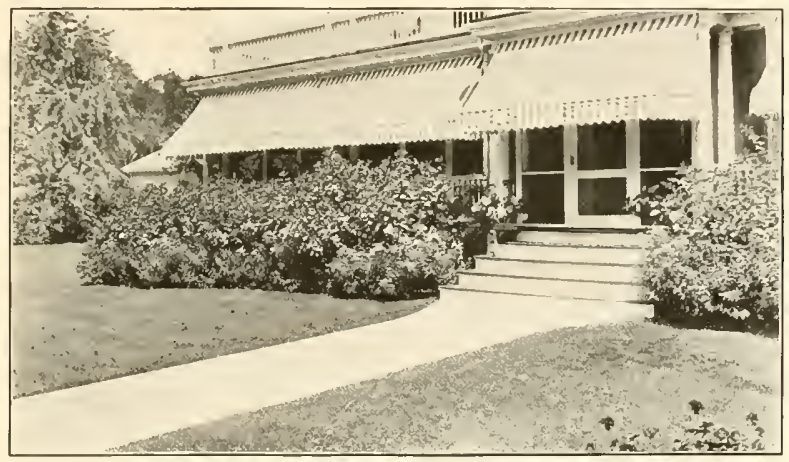

Enjoyment of veranda life is easily increased by a foundation planting of small-growing Deciduous Shrubs.

\section{Varieties attaining a height of 6 to 8 feet}

\section{WIITE FLOWERS}

Pearl Bush Exochorda grandiflora slender. Very showy in May with its profusion of starry flowers.

Chinese Privet

Ligustrum ibota spreading. Flowers small but numerous in June and July. Foliage especially pleasing. Prefers partial shade.

Mock Orange

Philadelphus coronarius Flowers fragrant, creamy-uhite.

Single Pure White Lilac

Syringa vulgaris Fran Bertha Dammann Hybrid. Fragrant flowers in late May.

Single Creamy White Lilac

Ilybrid. Fragrant flowers in late May.

Double Pure White Lilac s'yringa valgaris Hme. Lemoine 11 ybrid. Fragrant flowers in late May.

Japanese Snowball Viburnum tomentosum plicatum Large globular heads of pure white flowers in June. Foliage partieularly fine.

\section{PURPLE FLOWERS}

Single Reddish Purple Lilac Syringavulgaris Charle's I. Hybrid. liragrant flowers in late May.

Single Rosy Purple Lilac Syringa zulgaris Rubra de Marley Hybrid. Fragrant llowers in late Mlay.

\section{RED FLOWERS}

Red Weigela

Diervilla floribunda Blooms freely in May and June.

Single Dark Red Lilac

Syringa mlyaris Souvenir de Luduig Spath A hybrid variety of the Common Lilae. Large flower: in late May.

\section{PINK FLOWERS}

Double Rose Lilac Syringa rulgaris Belle de Nancy Ilybrid. Flowers brilliant satin rose iu late May. Fragrant.

Double Pink Lilac Syringa vulgaris $\mathrm{H}^{*} \mathrm{~m}$. Robinson Hybrid. Howers fragrant; late May.
“ T H E 


\section{Varieties Attaining a Height of 6 to 8 feet, Continued}

\section{YELLOW FLOWERS}

†Fortune's Golden Bell

Forsythia fortunei Ipright habit. Stems eovered with yellow bell-shaped flowers in April. Leaves rich green, turning purple in fall.

Golden Bell

Forsythia intermedia

Similar to Fortune's Golden Bell. Bloons more profusely. Branches placed in water indoors in winter soon spring into bloom.

†Drooping Golden Bell

Forsythia suspensa Branches drooping. Otherwise similar to Fortune's Golden Bell. Lower branches mat down and when planted on steep banks prevent soil washing.

\section{LAVENDER AND VIOLET FLOWERS}

Double Pale Violet Lilac

Syringa vulgaris Michael Buchner

11ybrid. Fragrant flowers in late May.

Double Lavender Lilac Syringa vulgaris President Carnot Iy'brid. Fragrant flowers in late May.

Persian Lilac

Syringa persica

Branehes more slender, leaves smaller than hybricls. Flowers fragrant, pale lavender in May and June.

Rouen Lilac

Syringa rothomagensis Similar to Persian Lilae. Fragrant flowers are purpleviolet. liree blooming in May.

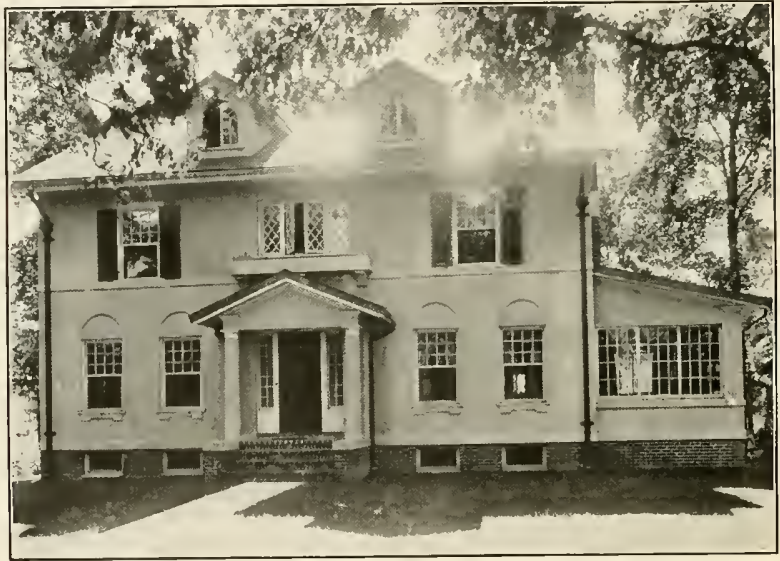

Without shrubbery to sof ten its bare foundation lines, even the most carefully planned home loses much in finish and charm

\section{A VARIETY VALUABLE FOR LEAF EFFECT}

Chinese Privet

Ligustrum ibota

Spreading habit. White flowers small but numerous in

June and July. Foliage especially rich shade of green.

Swall blue-blaek berries in fall.

\section{Varieties Attaining a Height of 5 to 6 feet}

\section{RED FLOWERS}

Red Japanese Quince

Blooms Mareh and April.

Bushy, compaet. Branches thorny:

${ }^{\dagger}$ Japanese Rose

Rosa rugasa

Foliage glossy dark green. Flowers single and fragrant from June to Deember. Stems densely covered with slender thorns. Bright scarlet fruit in fall and winter attraets birds.

F R A M I N G H A M
Japanese Quince

PINK FLOWERS

Blooms in Mareh and April.

Compact and dense. Branches thorny.

Pink Weigela Flowers freely in May and June.

Fragrant IIoneysuckle Fragrant flowers from March to May. Semi-evergreen
Diervilla rasea

Lonicera fragrantissima

Cydonia japonica F R A M I N G H A M, M A S S 


\section{DECIDUOUS FIOWERING SHRUBS FOR FOUNIDAION PLANTING}

Varieties Attaining Height of 5 to 6 feet. Coutinued

\section{YEII.OWISII-WHTE FLOWEIRS}

Japanese Oleaster

Likagnas longipes

Fragrant llowers in Ipril and Mlay. Sectrlet fruit ripens in $\mathbf{J}$ une and . duly.

\section{WHTE FI.OWERS}

White Weigela blooms freely in Mny and dune.

Japanese Bush lhoneysuckle Broad. Leaves dark green. Fruit blood-real.

White Kerria Bloon's in 1 lay and June.
Dirrilla alloa

Lonicera morrouii

Blooms in May ant lune. Rhodolypus lerrioides
tWhite Japanese Rose Foliage glossy dark grewn. Flowers single and fragrant from lnte to beember. Stems alcosely cevered with slender thorns. Fiorlet fruit in fall and winter attracts bircls.

Bridal Wreath Donble flowers in blay. Branelues slemer.

i Bridal Bower

Sipiraca ranhouttei Branches arehing; baves dark. Flowers almost comphetely cover the shrub ahout Memorial 1)at. One of the luest spring-llowering sloruhs.

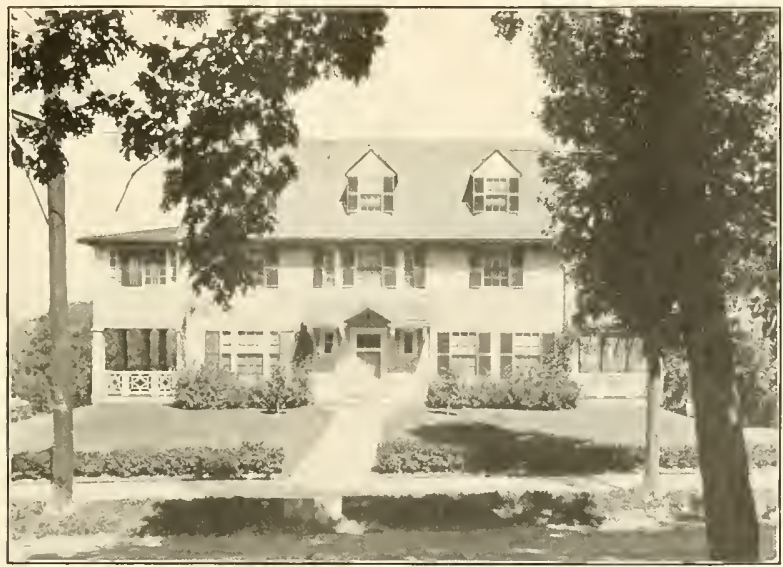

Note how much more warmly altractive how much more complete a homecan be made to fook by means of a simple foundation planting :

\section{IARIEIIES VALUABLE FOR LEAF AND FRUIT EFFECT}

tJapanese Rose

Rosa rugosa

Foliage shiny dark green. lied flowers, single and fragrant, from June to December. Stems covered with stender thorns. Searlet fruit in fall and winter attracts birds.

Japanese Oleaster

Eleagnus longipes

Fragrant yellowish-white flowers in April and May. scarlet fruit ripens in June and Iuly.
Japanese Bush Honeysuckle Leaves lark. Busliy hahit. White flowers in May and June, Fruit blood-red.

Standish's Honeysuckle Loniccre standistii small pink flowers in April. Leaves are dark and semievergreen.

†White Japanese Rose Rosa rugosa olba Flowers white. Otherwise the same as the preeding variety.

\section{Varieties Attaining a Height of 4 to 5 feet}

\section{PINK FLOWERS}

Pink Deutzia Double flowers in July. Inside of patels white.

Pink Almond Bushy habit. Double flowers almost eompletely cover the stems in May as the leaves are just starting.
Snowberry

Symphoriearpos racemosus

lBlooms in July and lugust. Bears waxy snow-white beries which remain during the greater part of the fall. llolds its teaves until very late making eontrast with the berries. Particularly goorl for shady places.
“ T H E
S T A N D A D
O F
Q U A I, I T Y
F O R
A M E R I C A" 


\section{Varieties Attaining a Height of 4 to 5 feet, Continued}

\section{YELLOWISH-ORANGE FLOWERS \\ Maule's Japanese Quince Cydonia japonica maulci Blooms in March and April. Dense shrub. Stem thorny.}

\section{BLUE FLOWERS}

Butterfly Bush Buddleia turiabitis magnifiea l'rofusion of large fragrant purplish blue spikes of flowers from August to (lctober. Dics back partly each winter but regains its size quickly. Very showy.

\section{WHITE FLOWERS}

Single White Deutzia Single blossoms tinged with rose in July.

Deutzia crenata

Snowball Ilydrangea IIydrangeu arbarescens grandiflara Bears large round clusters of creany white flowers throughont the summer. Foliage very fine.

White Almond Prunus japonica olba plena Double flowers about completely cover the stems in May as the leaves appear.

Dwarf Mock Orange Philadelphus lemoinei Loaled with white fragrant flowers suitable for cutting in Mlay and June.

Snow Gartand

Spiraca thunbergii

Foliage feathery. Stems are smothered with thousands of small white flowers in late April and early May.
Lace Shrub

Stephanandra flexuosa

Branches graceful and arching. Leaves dceply cut. J3looms in June.

\section{CIIOCOLATE-COLORED FLOWERS}

Carolina Allspice

Calycanthus flaridus

llooms all summer. Flowers have spicy odor.

\section{VARIETIES VALUABLE FOR LEAF AND FRUIT EFFECT}

tCoral Berry Symphoricarpos vulgaris Small crimson berries. Fine for shady places. Planted on steep banks, its thickly matted roots prevent soil washing.

$\dagger$ Regel's Privet

Ligustrum ibota regelianum Spreading habit. Small white flowers. Smooth leaves of deep rich green remaining till late in fall.

\section{Snowberry}

Symphoricarpos racemosus Small pink flowers in July and August. Bears waxy snow-white berries which remain all fall. IIolds its leaves until very late, making contrast with berries. particularly good for shady places.

†Siebold's Barberry

Berberis sicbaldi Leaves turn brilliant red in fall. Scarlet berries remain on stems late in winter.

\section{Varieties Attaining a Height of 3 to 4 feet}

\section{RED FLOWERS}

\section{Carmine Weigela Diervilla hybrida Eva Rathke} Erect; blooms profusely more or less throughout the summer.

\section{PINK FLOWERS}

Blume's Spiraed Spiraca blumei Roundish habit; flowers are in large cones in July.

Fortune's Spiraea Spiraea callasa Leaves purplish at first. Blooms in June.

\section{YELLOW FLOWERS}

Double Globe Flower Kerria japonica flare pleno. Deep orange yellow double flowers from June to September.
Shrubby Cinquefoil

Potentilla fruticasa

Blooms throughout the summer.

\section{WHITE FLOWERS}

Lemoine's Deutzia

Deutzia lemoinei Pure white single flowers in large clusters completely cover the shrub in Jiay and June. Blooms suitable for cutting. Plants good for indoor forcing. Very showy.

\section{A VARIETY VALUABLE FOR LEAF AND BERRY EFFECT}

\section{$\dagger$ Japanese Barberry Berberis thunbergii}

Broad bushy hahit. Branchlets drooping. Stems very thorny. Leaves small nearly round, turn brilliant red in fall, followed by scarlet fruit which remains on stems the greater part of the winter.

\section{Varieties Attaining Height of 1 to 3 feet}

\section{RED FLOWERS}

†Crimson Everblooming Spiraea

$$
\text { Spiraea bumalda Anthany } \text { Hatcrer }^{*}
$$

Flowers in flat panicles profuse in July and August.

\section{PINK FLOWERS}

†Pink Everblooming Spiraea

Flowers in flat panicles in July and August.

\section{YELLOW FLOWERS}

St. John's Wort

IIypericum aureum Blooms frecly all summer. Witlıstands shade and drought.

Globe Flower

Kerria japonica

Foliage bright green. Large flowers all summer long.

Silver-leaved Globe Flower

Kerria japonica tariegata Leaves variegated with white. Blooms in nid-summer.
F R A M I N G H A M
N U R S E R I E 


\section{Varieties Attaining Height of 1 to 3 feet, Continuel}

\section{BL, UE FLOWERS}

Lead Plant

A marpha ranescens.

Free flowering in dume. Prefers sunny pusition. Sueceds in ratlier dry soil.

\section{WHTE FIOWERS}

New Jersey 'Te:

Ceanathus americanus Blooms freely from July to septemler. laluable for dry sandy soits, hut will grow in almost any kind.

\section{Dwarf Deutzia}

Drutzia gracilis

Branehes slender, labit nearly globular when malure. Blooms in Vtay and June. Iny well drained soil.
Golden Syringa

Philadel phus coromarius aureus Compact round shrub when mature. Leaves are bright yellow. The lest of the golden-leaved slurubs. BJluoms in June.

SARIETIES VALAABLE FOR TIIEIR IEAF EFFEC"T

Silver-leafed Globe Nlower

Kerria jupanion variegata leaves variegated with white. Sollow flowers in mitsummer.

Golden Syringa Philadelphus coronarius aurens The best of the golden-leaved varicties. Fragrant white flowers in June.

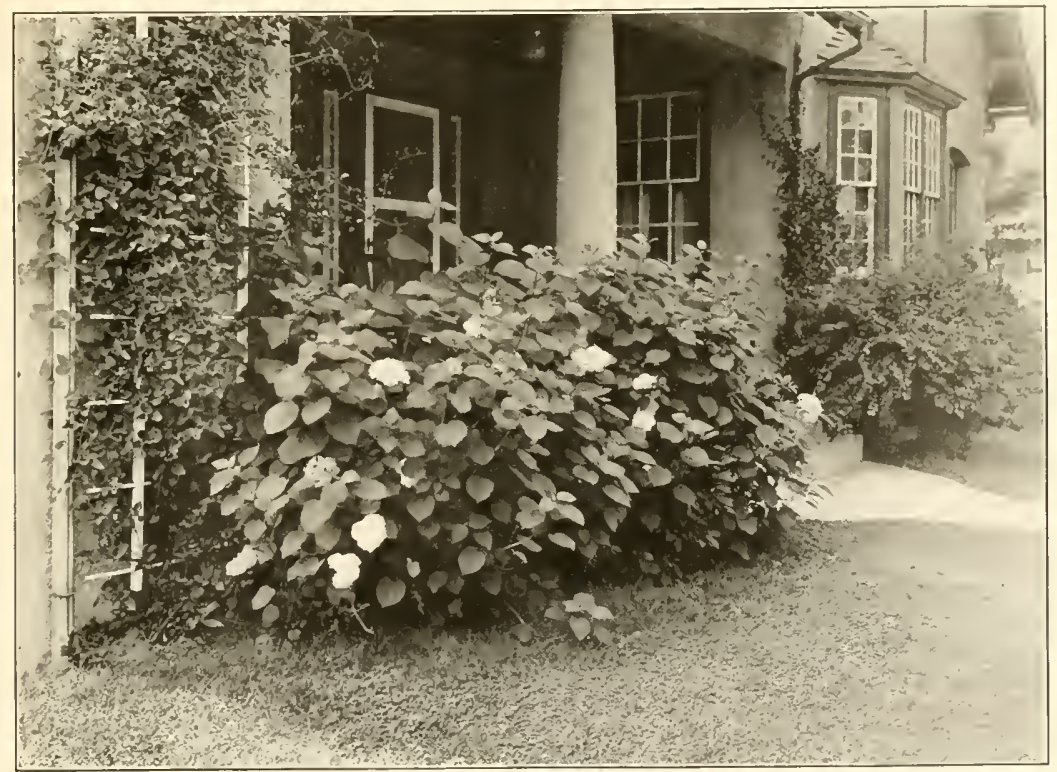

An effective grouping of mixed deciduous shrubs about an entrance

\section{PRICES}

Owing to seasonal fluctations in the prices of nursery stoek we have diseontinued the practice of inserting prices in this general deseriptive eatalog. The information in this book holds good over a long period and for this reason we recommend its preservation. Seasonal price lists will be mailed you twice a year-Mareh 1 st and September Isı. If however you do not receive them please notify us.
“ TH E
S T A N D A R D
$\mathrm{O} \mathrm{F}$
Q U A L I T Y
F O R
A M E R I C A" 
Owing to their halit of holding their foliage the year round, Evergreens are becoming more and more popular.

Since most Evergreens atlain an ultimate height too great to classify in the same manner as shrubs, we are presenting them in a different way. Mlthough they ultimately attain a large size, their slow rate of growth makes them practical for Fomdation Planting.

Almost all of the varieties here listed may he sucessfully sheared and thus kept from getting too large.

Consequently we list Evergreens not by ultimate height, but by varieties and sizes suitable for various size houses.

Obviously a large house should have larger plants, and more of them, than a medium sized or small house. For that reason, we are listing Evergreens for "Foundation Planting" in tliree groups:

Group A - Suitable for a Large House.

Group B-Suitable for a Medium sized house.

Group C - Suitable for a Small Ho'se or Bungalou.

The rule of distances for planting deciduous shrubs does not apply to Evergreens. The latter should be planted so that the distance between branches is from 8 to 19 inches. To enalie the amaten gardener to plan the number of Evergreens needed our list gives the average breadth of the plant as well as the height. This breadth measurement is taken near the gromel, except in plants that are fan-shaped in which ease the widest breatth is given

Where the larger suggested size is selected for the back row, the larger suggested sizes should genemally be used in the other rows.

It is not advisable to plant golien forms next to blue forms. Siparate by planting one or two green forms between.

\section{EVERGREENS SUITABLE FOR A LARGE HOUSE}

\section{Back Row - Between Windows - In Corners - And About Angles}

Golden Virginia Cedar Blue Virginia Cedar

American Arborvitae

Peabody's Golden Arborvitae

Pyramidal Arborvitae

Douglas's Pyramidal Arborvitae
Red Cedar

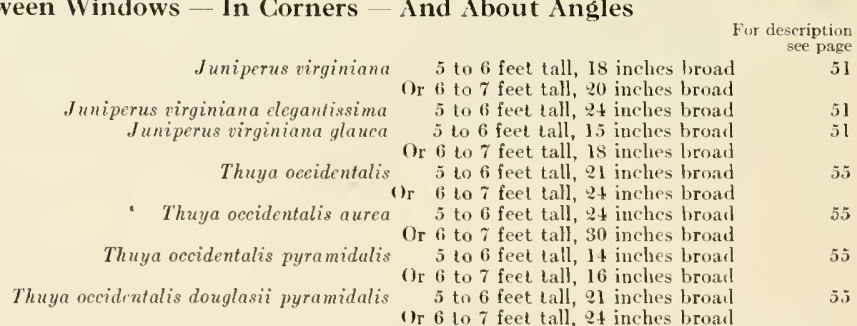
Sometimes it is advisable to use even larger trees. In such a case we shall be glad to quote on irees larger than we list here.

\section{Back Row - Under Windows}

Chinese Juniper

Silver-tipped Chinese Juniper

Juniperus chinensis
Juniperus chinensis argentea

3 to 4 feet tall, 24 inches broad Or 4 to 5 feel tall, 30 inches broad 3 to 4 feet tall, 27 inches broad Or 4 to 5 feet tall, 33 inches broad

NUR SER I E S - F R A M I N G H A M, MA S S. 


\section{Back Row - Under Windows, f'ontinned}

Polish Juniper

Irish Juniper

Swedish Juniper

Pea-fruited Cypress

Golden Pea-fruited Gypress

Plumed Cypress

Golden Plumed Cypress

Siberian Arborvitae

Vervaene's Arborvitac

\section{Second Row - Between Windows, in Corners and About Angles}

Clinese Juniper

Silver-tipped Chinese Iuniper

Irish Juniper

Swedish Juniper

Red Cedar

Blue Cedar

Pea-fruited Cypress

Golden Pea-fruited Cypress

Golden plumed Cypress

Anerican Arborvitae

Peabody's Golden Arborvitae

Pyramidal Arborvitae

Douglas's Pyramidal Arborvitae

Siberian Arborvitae

Chinese Juniper

Silver-tipped Chinese Juniper

Golden Chinese Juniper

Polish Juniper

Irish Juniper

Swedish Juniper

Greek Juniper

Golden Japanese Juniper

Thread-branched Cypress

Pea-fruited Cypress

“T II E

S T A N D A R D
Juniperus communis cracovin

Juniperus communis hibernice

Inniperus communis suecicu

Retinispora pisifera

Retinispora pisifera aurea

Retinispora plumosa

lictinispora plumosa anrea

Thuya aceidentalis siberica

Thuy occidentalis vervaenana

3 to 1 fect tall, 1 is inches broal

Or t to 5 feet tall, 18 inches broad

3 to 4 feet tall, 12 inches broal

(1) $t$ to 5 fect tall, 15 inclies broad

3 to 4 feet tall, 12 inches broad

()) + to 5 feet tall, 15 inches broad

3 to 4 feet tall, 21 inches broad

Or to to 5 feet tall, 30 inches broad 3 to + feet tall, $2+$ inches broad () 1 to 5 feet tall, 30 inche; broac

() 5 to 6 feet tall, 33 inches broad () 3 to 1 feet tall, 2 inchen broad 3 to 4 feet tall, 24 inches broad 3 to 4 feet tall, 18 inches lorosed $O_{r}$ b to 5 feet tall, 30 inches broad 3 to 4 feet tall, 27 inches broad

Or + to 5 feet tall, 30 inches broad 3 to 4 feet tall, 30 inches broud

() + to 5 feet tall, 33 inches broas
Thuya occidentalis pyramidalis

Thuya occidentalis douglasii pyramidalis

Thuya occidentalis siberien

For deccription see page

4 to 5 feet tall, 30 inclues broal

Or 5 to 6 feet tall 33 inclies loroal 1 to 5 feet tall, 33 inclues broad () 3 to 6 feet tall, 36 inches broul 4 to 5 feet tall, 15 inclues breas () 5 to 6 feet tall, 15 inches broal $t$ to 5 feet tall, 15 inches broal

()r 5 to 6 feet tall, 15 inches broad 4 to 5 feet tall, 15 inches broad 1) 5 to 6 feet tall, is inches broad 4 to 5 feet tall, 12 inches broad () 5 to 6 feet tall, 15 inches broad 4 to 5 peet tall, 30 inclies loroad

(1) 5 to 6 feet tall, 33 inches broad $t$ to 5 feet tall, 30 inches broad

()r 5 to 6 feet tall, 33 inches broid

+ to 5 feet tall, 30 inches broad (Ir 5 to 6 feet tall, 33 inches broad 4 to 5 feet tall, 18 inches broad (1) 5 to 6 feet tall, 21 inches broad 4 to 5 feet tall, 21 inclies broad

(1) 5 to 6 feet tall, 24 inches broad 4 to 5 feet tall, 12 inches bruad () 5 to 6 feet tall, 14 inches broad 4 to 5 feet tall, 18 inches broad ()r 5 to 6 feet tall, 21 inehes broad 4 to 5 feet tall, 30 inches broid () 5 to 6 feet tall, 33 inches broal

\section{Second Row - Under Windows}

$$
\begin{aligned}
& \text { Juniperuschinensis } \quad 21 / 2 \text { to } 3 \text { feet tall, } 21 \text { inches broad } \\
& J \text { uniperus chinensis argentea } \quad 2 \frac{1}{2} \text { to } 3 \text { feet tall, } 21 \text { inches broad } \\
& \text { Juniperus chinensis aurea (Or } 3 \text { to } 4 \text { feet tall, } 27 \text { inches broad } \\
& \text { to } 3 \text { teet tall, } 14 \text { inches broat } \\
& \text { Juniperus communis cracovia } 2_{2} y_{2} \text { to } 3 \text { feet tall, } 14 \text { inches broad } \\
& \text { Or } 3 \text { to } 4 \text { feet tall, } 16 \text { inches broad } \\
& \text { Juniperus communis hibernica } \quad z_{2}^{1} \text { to } 3 \text { feet tall, } 10 \text { inches broad } \\
& \text { Juniperus communis surcica } \\
& \text { s } 2 \text { to seet tall, } 10 \text { inches broad } \\
& \text { I uniperus excelsa stricta } 2,2 \text { to } 3 \text { feet tall, } 27 \text { inches broad } \\
& \text { ()r } 3 \text { to } 4 \text { feet tall, } 33 \text { inches broad } \\
& \text { Inniperus japonica aurea } \quad 2 \frac{1}{2} \text { to } 3 \text { feet tall, } 30 \text { inches broad } \\
& \text { ()r } 3 \text { to } 4 \text { feet tall, } 36 \text { inches broad } \\
& \text { Retinispora filifera } \quad 2 \frac{1}{2} \text { to } 3 \text { feet till, } 2 \text { inches broald } \\
& \text { Retinispora pisifera () } 3 \text { to } 4 \text { feet tall, } 28 \text { inches broad } \\
& \text { Or } 3 \text { to }+ \text { feet tall } 2 \text { f inches broad }
\end{aligned}
$$
O F
Q U A L I T Y
F O R
A M E R I G $A$ ", 
Golden Pea-fruited Cypress

Plumed Cypress

Golden Plumed Cypress

Veitch's Cypress

Siberian Arborvitae

Hovey's Golden Arborvitae

Oriental Arborvitae

Globe Hemlock

Chinese Juniper

Silver-tipped Chinese Juniper

Golden ChInese Juniper

Irish Juniper

Swedish Juniper

Greek Juniper

Golden Japanese Juniper

Savin Juniper

Mountain Pine

Dwarf Mountain Pine

Thread-branched Cypress

Pea-fruited Cypress

Golden Pea-fruited Cypress

Plumed Cypress

Golden Plumed Cypress

Umbrella Pine

Globe Arborvitae

Siberian Arborvitae

Oriental Arborvitae

Globe Hemlock

Great Laurel

Catawban Rhododendron

Ifybrid Catawban Rhododendron

Mountain Laurel
Second Row - Under Windows, Conlinued

For description see page

Retinispora pisifera aurea $\quad z \frac{1}{2}$ to 3 feet tall, 20 inches broad $2, \frac{1}{2}$ to 3 feet tall, 20 inches broad

Or 3 to 4 feet tall, 24 inches broad
2 to $21 / 2$ feet tall, 24 incbes broad Or $21 / 2$ to 3 feet tall, 30 inches broad

Thuya occidentalis siberiea $2 \frac{1 / 2}{}$ to 3 feet tall, 21 inches broad

Thuya accidentalis hoveyi $2_{1 / 2}$ to 3 feet tal1, 20 inches broad Thuya arientalis Or 3 to 4 feet tall, 24 inches broad

Tsuga canadensis glabosa Or 3 to $\$$ feet tall, 18 inches broad Or 3 to 4 feet tall, 40 inches broad

\section{Third Row}

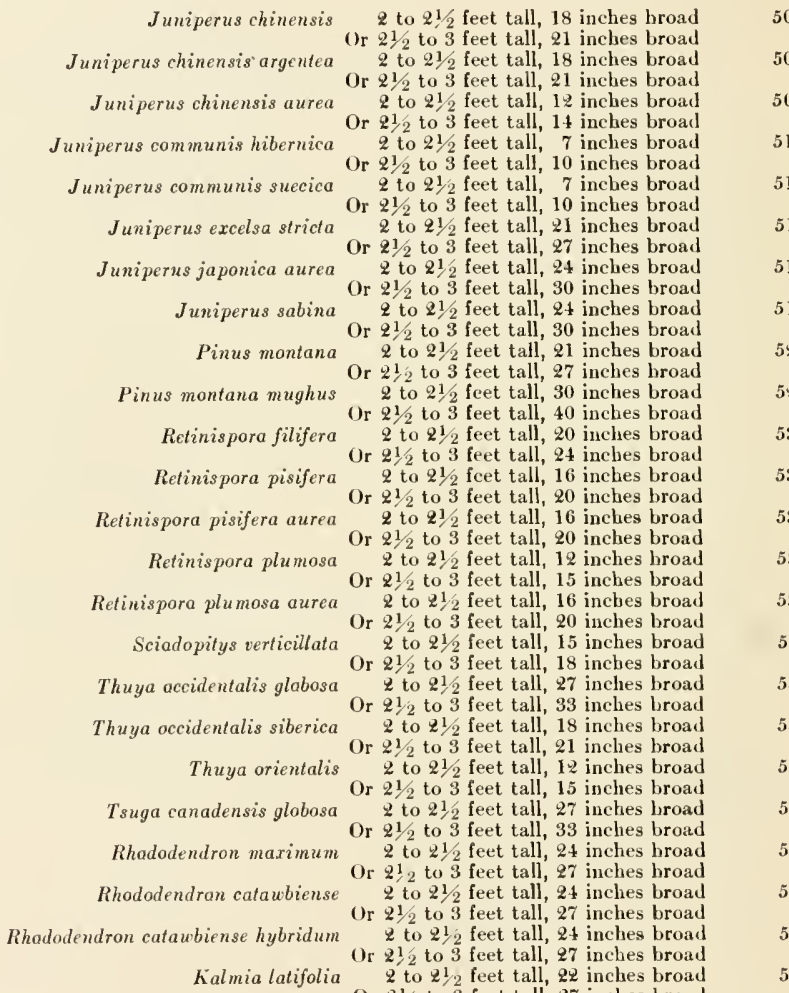

50

50

50

51

51

51

51

52

52

53

53

53

53

53

Fourth Row
Greek Juniper

Japanese Juniper

Juniperus excelsa stricta 15 to 18 inches tall, 15 inches broad

Juniperus japonica

Or 18 to 24 inches tall, 18 inches broad

15 to 18 inches tall, 14 inches broad Or 18 to 24 inches tall, 18 inches hroad

51

51

F R A M I N G H A M 
Savin Juniper

Tamarisk-leaved Jumiper

Globe-shisped Red Cedir

Dwarf Mountain Pine

Golden 'Thread-branched Cypress Plumed Cypress

Globe Irborvitale

Dwarf Japanese lew

Ashberry

Carolina Rhododendron

Mountain Laurel

Drooping Andromeda

Lily of the Valley Shrub

Evergreen Bittersweet

Large-leaved Evergreen Bittersweet

Variegated Evergreen Bittersweet

Brond-leaved Evergreen Bittersweet
Fourth Row, Continued

Juniperus sabina 15 to 18 incless tall, 15 inches broad

51

Or is to 21 inclues tall, is inches broall

Juniperus sabina tamariscifolia 12 to 15 inchrs tall, 12 to 15 inchrs broita?

Or 15 to is inclies tall, 15 to 18 inches browil

Juniperus virginiana globasa 15 to 18 inches tall, 15 to 18 inches broiul

Or 18 to 21 inches tali, 18 to $2+2$ inclees broall Pinus montana mughus 12 to 15 inclexs tall, 15 to 18 inches liroiul Or 15 to 18 inches tall, 18 to 25 inches broats

Retinispora filifera aurea 15 to 18 inches tall, 18 to 24 inches broal hetinispora plumasa 15 to 18 inche's till, 10 inches brouil

Or is to 24 inches tall, 12 inches loroatl

Thuya occidentalis globosa 15 to 18 inches tall, 15 to 18 inchr's broat

Or 18 to 21 inches tall, 18 to 24 inches lireatul

Taxus cuspidata nana 12 to 15 inches tall, 15 to 18 inches broud

Or 15 to 18 inches tall, 18 to $2+$ inches hrousl

Berberis aquifolium 15 to 18 inches tall, 12 inches hroar!

() 18 to 24 inches tall, 15 inches liroat

Ribododendron carolinianum 15 to 18 inches tall, 15 inches broad

Or 18 to $2 \mathrm{l}$ inches tali, 18 inches broukl

Kalmia latifolia 15 to 18 inches tall, 15 inches broad

Or 18 to 24 inches tall, 22 inches broad

Leucothoe catesbaei 12 to 15 inches tall, 12 inches broad

()r 15 to 18 inclies tall, 1.5 inches liroad

Pieris floribunda 12 to 15 inches tall, 12 to 15 juches broud Or 15 to $1 \mathrm{~s}$ inches tall, 15 to 18 inches broat

Euonymus radicans 10 to 12 inches tall, $(i$ to 8 inches broud

Euonymus rativons grandifolia 10 to 12 inches tall, 8 to 10 inches broal

Euonymus radicans variegata 10 to 12 inches tall, 6 to 8 inches broad

Euonymus radicans vegeta 8 to 10 inches tall, 8 to 10 inches broat
51

51

5.)

53

.53

5.5

5.1

56;

57

$56 ;$

56

56

is

56

$51 ;$

56

\section{EVERGREENS SUITABLE FOR A MEDIUN-SIZED HOUSE}

\section{Back Row - Between Windows, in Corners and About Angles}

Chinese Juniper

Silver-tipped Chinese Juniper

Irish Juniper

Swedish Juniper

Red Cedar

Blue Cedar

Pea-fruited Cypress

Golden Pea-fruited Cypress

Plumed Cypress

Golden plumed Cypress

American Arborvitae

Peabody's Golden Arborvitue

Pyramidal Arborvitae

Houglas's Pyramidal Arborvitae

Siberian Arborvitae

Chinese Juniper

Silver-tipped Chinese Juniper

Golden Chinese Juniper

"T H E S T A N D A R D

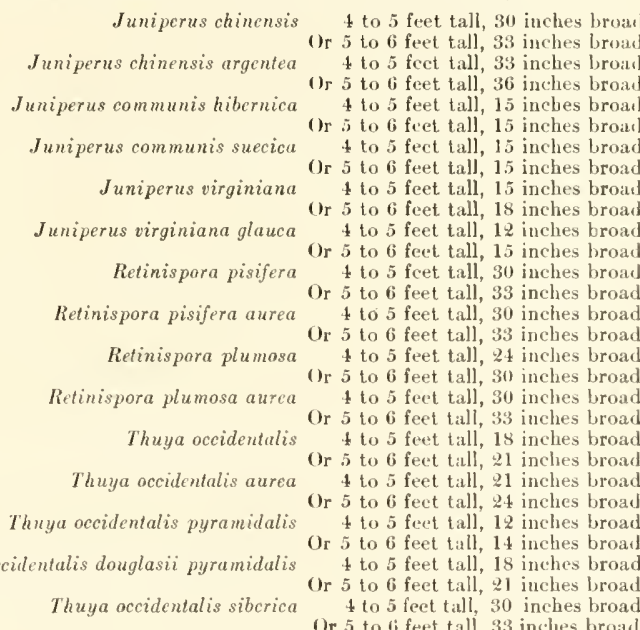

50

$\$ 0$

51

Back Row - Under Windows

$$
\begin{aligned}
& \text { Juniperus chinensis } \quad 21 / 2 \text { to } 3 \text { feet tall, } 21 \text { inches broad } \\
& \text { Or } 3 \text { to } 4 \text { feet tall, } 24 \text { inches broad }
\end{aligned}
$$

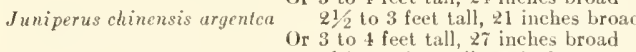

$$
\begin{aligned}
& \text { Juniperus chinensis aurea } 2 \frac{1}{2} \text { to } 3 \text { fcet tall, } 14 \text { inches broad }
\end{aligned}
$$

O F Q U A L I T Y F O R A M E R I G A ", 


\section{Back Row - Under Windows, Contimued}

For description see page

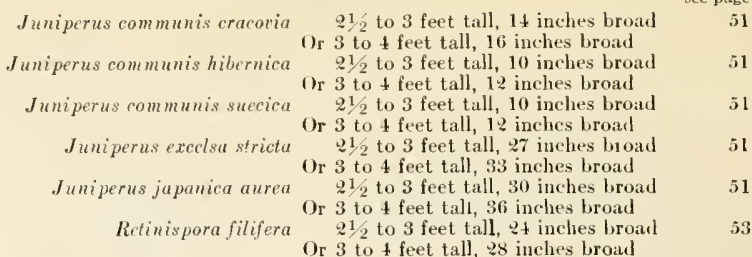

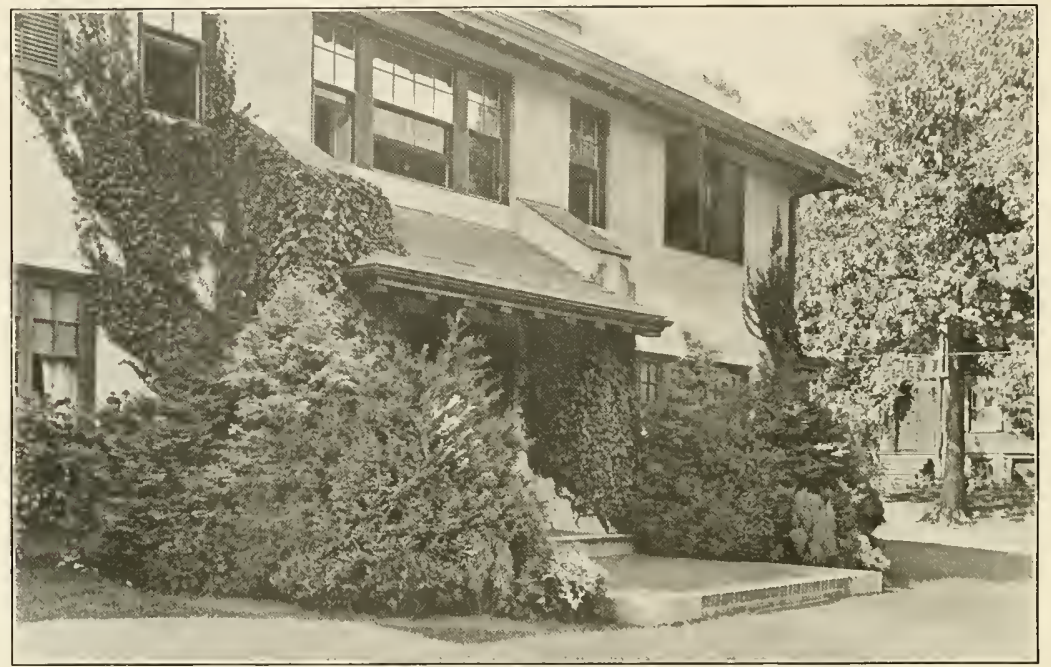

What a charming, "cozy" effect has been obtained by massing foundation evergreens at each side of the entrance of this home! Note also the use of Vines.

Pea-fruited Cypress

Golden Pea-fruited Cypress

Plumed Cypress

Golden Plumed Cypress

Siberian Arborvitae

llovey's Golden Arborvitae

Oriental Arborvitae

Globe Hemlock

Chinese Juniper

Silver-tipped Chinese Juniper

F R A M I N G H A M

\begin{abstract}
Retinispara pisifera $\quad 21 / 2$ to 3 feet tall, 20 inches broad () 3 to 4 feet tall, 24 inches broad Retinispora pisifera aurea $21 / 2$ to 3 feet tall, 20 inches broad Retinispara plumasa Or $21 / 2$ to 3 feet tall, 15 inches broad Or 3 to 4 feet tall, 18 inches broal Retinispara plumosa aurea $21 / 2$ to 3 feet tall, 20 inches broad ()r 3 to 4 feet tall, 24 inches broad Thuya accidentalis siberica 21,2 to 3 feet tal], 21 inches broad Thuya arcidentalis hareyi $21 / 2$ to 3 feet tall, 20 inches broad Or 3 to 4 feet tall, $2+$ inches broad Thuya arientalis $2 \frac{1}{2}$ to 3 feet tall, 15 inches broad

Tsuya canudensis glolosa
()r 3 to 4 feet tall, 18 inches broad
$21 / 2$ to 3 feet tall, 33 inches broad ()r 3 to 4 feet tall, 40 inches broart
\end{abstract}

\section{Second Row}

Juniperus chinensis 2 to $21 / 2$ feet tall, 18 inches broad Or $21 / 2$ to 3 feet tall, 21 inches broad Juniperus rkinensis argentea 2 to $21 / 2$ feet tall, 18 inches broad
Or $2 \frac{1}{2}$ to 3 feet tall, 21 inches broad N U R S E R I E - F R A M I G H A M, MA S S. 
Golden Chinese Juniper

Irish Juniper

Swedish Juniper

Greek Juniper

Golden Japanese Juniper

Savin Juniper

Mountain Pine

Dwarf Mountain Pine

Thread-branched Cypress

Pea-fruited Cypress

Golden Pea-fruited Cypress

Plumed Cypress

Golden Plumed Cypress

Uimbrella Pine

Globe Arborvitae

Siberian Arborvitae

Oriental Arborvitae

Globe Hemlock

Grent Laurel

Catawban Rlıododendron

Hybrid Catawban Rhododendron

Mountain Laurel

\section{Greek Juniper}

Japanese Juniper

Savin Juniper

Tamarisk-leaved Juniper

Globe-shaped Red Cedar

Dwarf Mountain Pine

Golden Thread-branched Cypress Plumed Cypress

Glohe Arborvitae

Dwarf Japanese Jew

Ashberry

Carolina Rbododendron

Mountain Laure]

Drooping Andromeda

“T H E S T A N D A R D
Second Row - Comlinued

1.or deseription sin inge

Jnuiperus chimensis aurca 2 to 21.2 feet tall, $1 \%$ inclies broad (1) $2 \mathrm{t}, 203 \mathrm{fect}$ tall, 14 inches broul

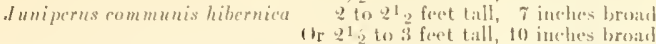
Juniperus communis sucrica 2 to $21{ }_{2}^{1}$ feet tall, 7 incles broal

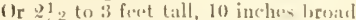
Junipcrus cxeclsa stricta 2 to $21 / 2$ foct tall, 21 inches broad (1) $21 / 2$ to 3 feret tall, 27 inches broit I uniperus japonira aurea 2 to 21 , fort tall, 21 inches broiul (1) 21.2 to 3 furet tall, 30 inches broitl Iuniperus sabina $\begin{gathered}2 \text { to } 21 / 2 \text { frect tall, } 24 \text { inclues hrwal } \\ \text { (or } 21,2 \text { to } 3 \text { fert tall, } 30 \text { inclues bresul }\end{gathered}$ pinus montana g to 23,2 fert tall, 21 inches broul (1) 21 to 3 feet tall, 27 inches broit

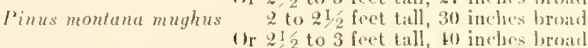
letimispora filifura of to 21 foet tall, $a_{9}$ inches brual (ir 212 to 3 feet tall, 24 inches hroiul Retimispora pisiferu 2 to $21 / 2$ feet tall, 16 inclyes broid

(1) $21 \%$ to 3 feet tiall, 20 inclies brom lietinispora pisifera aurra 2 to 21,2 feet tall, 16 inches broad t)r $2 \frac{1}{2}$ to 3 feet tall, 20 inches broit 2 to $21 \%$ feet tall, 12 inches hroirt Or $21 / 2$ to 3 feet tall, 15 inclies broat

Retinispora plumosa aurea $22^{2} 2^{1}$ feet titll, 16 inches broal Sciadopitys verticilluta 2 to 21,2 feet tall, 15 inches broul Or 21, to 3 feet tall, is inches broad

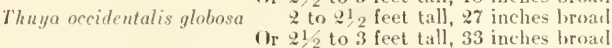

Thuy a ocidentulis siberica 2 to $21 / 2$ feet tall, 18 inches broat
()r $21 / 2$ to 3 fcet tall, 21 inches broad Thuya oricntalis 2 to 21,2 feet tall, 12 inches broal 2 to 212 feet tall, 12 inches broad
$21 / 2$ to 3 feet tall, 15 inclies broad Tsuga canadensis globosa 2 to 212 feet tall, 27 inches broal

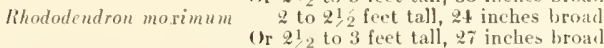
Bhododendron catawbiense 2 to $21 / 2$ feet tall, 24 inches broal ()r $2^{1} 2$ to 3 feet tall, 27 inches broarl Whototendron cutambiense hybrita 2 to $21 / 2$ feet tall, 24 inches broal () $121 / 2$ to 3 fect tall, 27 inehes broat halmialutifolia 2 to $2^{1}$ feet tall, 22 inches broad Or $21 / 2$ to 3 fect tall, 27 inches broad

in)

.1 1

it

51

$5 \mathrm{t}$

st

52

$5:$

53

$5: 3$

$\$ 3$

$.5: 3$

5:3

53

.5

55

i.i

55

Third Row

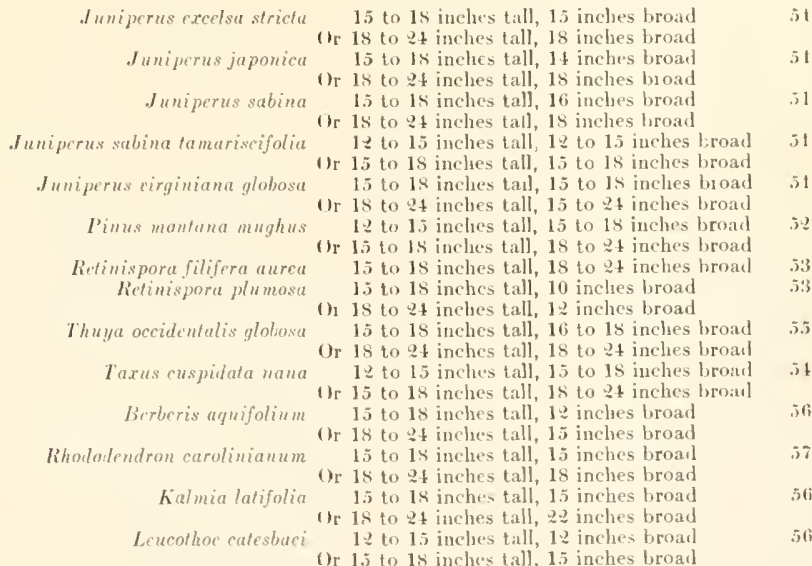
() 1.5 to 18 inclues tall, 15 inches broal

(1)

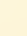

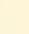

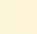

3

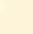

(n)

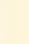

i
O F
Q U A L I T Y
F O R
A M E R I C A", 
Lily of the Valley Shrub

Evergreen Bittersweet

Large-leaved Evergreen Bittersweet

Variegated Evergreen Bittersweet

Broad-leaved Evergreen Bit tersweet
Third Row, Continued

For description
see page

Pieris floribunda 12 to 15 inches tall, 12 to 15 inches broad 56 Or 15 to 18 inches tall, 15 to 18 inches broad 56

Euanymus radicans 10 to 12 inches tall, 6 to 8 inches broall 56 Euonymus radicans grandifolia 10 to 12 inches tall, 8 to 10 inches broad 56 Euonymus radicans rariegata 10 to 12 inches tall, ti to s inches broad 56

Euonymus radieans regeta 8 to 10 inches tall, 8 to 10 inches broad 56

\section{EVERGREENS SUITABLE FOR A SMALL HOUSE OR BUNGALOW}

Note: The following assortment is primarily for small houses on low foundations. If your house is set on a high founda. tion, as is sometimes the case with bungalows, the assortment of "Evergreens suitable for a IIedium-Sized Ilouse" will be more desirable. Vie rersa - if a medium-sized house is set on very low foundations, the following lists will be more suitalle.

\section{Back Row - Between Windows, in Corners, and About Angles}

Polish Juniper

Swedish Juniper

Red Cedar

Pea-fruited Cypress

Golden Pea-fruited Cypress

Plumed Cypress

Golden Plumed Cypress

American Arborvitae

Peabody's Golden Arborvitae

Douglas's Pyramidal Arborvitae

Pyramidal Arborvitae
Irish Junjper
Juniperus communis cracoria 3 to 4 feet tall, 16 inches broad

Or 4 to 5 feet tall, is inches broad

3 to $\$$ feet tall, 12 inches broad

Or 4 to 5 feet tall, 15 inches broad

Or 4 to 5 feet tall, 15 inches broad 3 to $\$$ feet tall, 12 inches broad

Or 4 to 5 feet tall, 15 inches broad 4 to 4 feet tall, 24 inches broad Or 3 to 5 feet tall, 30 inches broar 3 to $\$$ feet tall, 24 inches broad

Or $\&$ to 5 feet tall, 30 inclies broad 3 to $\&$ feet tall, 18 inches broad 3 to $\$$ feet tall, 24 inches broad

Or 4 to 5 feet tall, 30 inches broarl 3 to 4 feet tall, 15 inches broal

Or 1 to 5 feet tall, 18 inches broarl 3 to 4 feet tall, 18 inches broarl Or $\$$ to 5 feet tall, 21 inches broal 3 to 4 feet tall, 15 inches broal Or $\&$ to 5 feet tall, 18 inches broarl 3 to 4 feet tall, 12 inches broad (Or 4 to 5 feet tall, 12 inches broal 3 to 4 feet tall, 12 inches broad

51

Back Row Under Windows, and Front Row Between Windows, in Corners, and About Angles Chinese Juniper

Silver-tipped Chinese Juniper

Golden Chinese Juniper

Irish Juniper

Swedish Juniper

Greek Juniper

Thread-branched Cypress

Pea-fruited Cypress

Golden Pea-fruited Cypress

Plumed Cypress

Golden Plumed Cypress

Umbrella Pine

Siberian Arborvitae

Oriental Arborvitae

Great Laurel

Catawban Rhododendron
2 to $2 \frac{1}{2}$ feet tall, 18 inches broad

Or $21 / 2$ to 3 feet tall, 21 inches broad 2 to $2 \frac{1}{2}$ feet tall, 18 inches broad (1) $21 \%$ to 3 feet tall, 21 inches broad 2 to $21 / 2$ feet tall, 12 inches broad Or $2^{1}$ to 3 feet tall, 14 inches broad

$J$ uniperus communis hibernica 20 to 21 feet tall, 7 inches broad
Or $21 \frac{1}{2}$ to 3 feet tall, 10 inches broad

Juniperus communis suecica 2 to $21 / 2$ feet tall, 7 inches broad

Juniperus excelsa stricta 2 to $21 / 2$ feet tall, 21 inches broad

Or $21 / 2$ to 3 feet tall, 27 inches broad

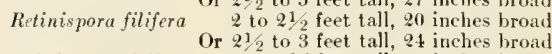
Retinispora pisifera 2 to $21 / 2$ feet tall, 16 inches broad

Or $21 / 2$ to 3 feet tall, 20 inches broad

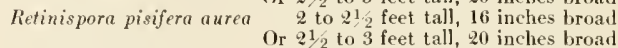

Retinispora plumosa 2 to 21 feet tall, 12 inches broad

Or $21 \frac{2}{2}$ to 3 feet tall, 15 inches broad

Retinispora plumosa aurea

Sciadopitys verticillata

Thuya occidentalis siberica

Thuya orientalis

Rhododendron maximum

Rhododendron calawbiense
Or $21 / 2$ to 3 feet tall, 20 inches broar 2 to $21 / 2$ feet tall, 15 inches broad Or $2 \frac{1}{2}$ to 3 feet tall, 18 inches broad 2 to $21 / 2$ feet tall, 18 inches broad Or $21 / 2$ to 3 feet tall, 21 inches broat 2 to $21 \%$ feet tall, 12 inches broarl

Or 21 to 3 feet tall, 15 inches broad 2 to $2 \frac{1}{2}$ feet tall, 24 incbes broad Or 212 to 3 feet tall, 27 inches broad 2 to $21 / 2$ feet tall, 24 inches broad Or $21 / 2$ to 3 feet tall, 27 incles broad
Or 21,2 to 3 feet tall, 10 inches broad 2 to 21,2 feet tall, 16 inches broad 
Back Row, etc., l'ontinued

Ther deseription

Ilybrid Catawban Rhododendron

Rhododendron catawbiense hybridum 2 to 21,2 feet tall, 21 inclues broad (1) $22_{2}$ to 3 feet tall, 27 inche broul

Mountain laturel

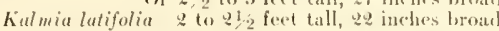
1) 21,2 to 3 foed tall, 28 inclues l, road

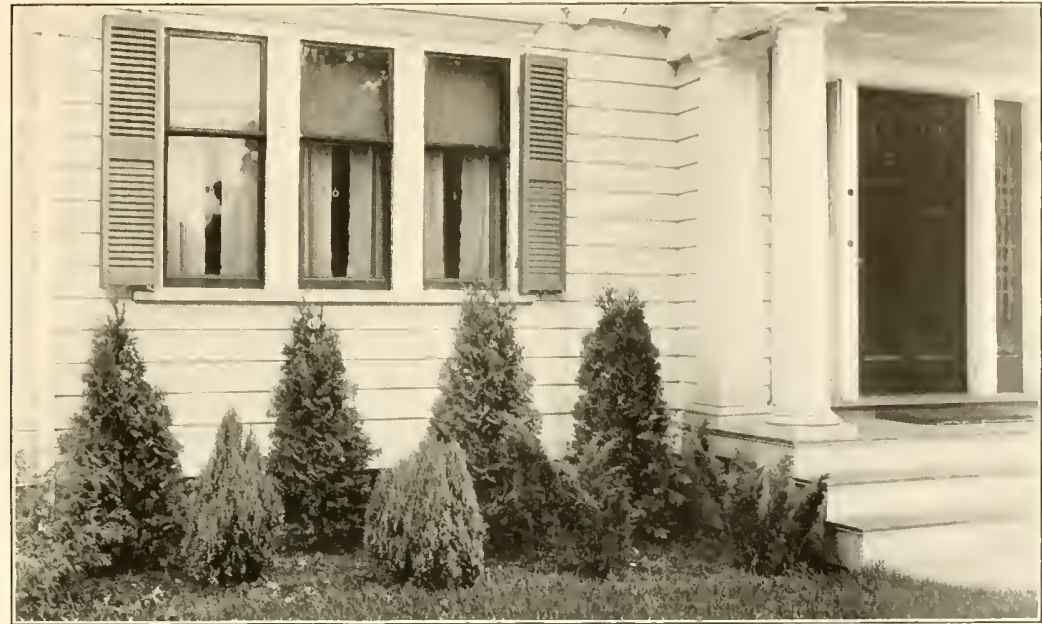

A simple but permanently attractive foundation planting of evergreens.

Front Row-Under Windows

Greek Juniper

Japanese Juniper

Savin Juniper

Tamarisk-leaved Juniper

Glohe-shaped Red Cedar

Dwarf Mountain Pine

Golden Thread-branched Cypress Plumed Cypress

Globe Arborvitae

Dwarf Japanese lew

Ashberry

Carolina Rhododendron

Mountain Laurel

Drooping Andromeda

Lily of the Valley Shrub

Evergreen Bittersweet

Large-leaved Evergreen Bittersweet

Globe-shaped Red Cedar

Broad-leaved Evergreen Bittersweet
Juniperus exedsa strictu

Juniperus juponica

Inmiperus sabind

Inniperus sabina tamariscifolia

Juniperus virginiana globosa

Pinus montana mughus

Rutinispora filifera aurea Retinispora plumasa

Thuyo ocridentalis globosa

Taxus cuspidata mana

Berberis aquifolium

Rhoulodendran curolinionum

Íalmia latifolia

Leucothoe catesbaci

Picris floribunda

Euanymus radicans Euonymus radicans grandifolia

Juniperus virginia globosa

Euonymus radicans regeta
15 to 18 inches lall, 15 inches lormal ) 18 to 24 inches tall, 18 inches hroiul 15 to 18 inches tall, 14 inches broad

(1) 18 to $2+$ inches tall, 18 inches broad 1.5 to 18 inches tall, 15 inches broat 1) 18 to $2 \mathrm{t}$ inches tall, 18 inches broad 12 to 15 inches tall, 12 to 15 inches hroad 1)r 15 to 18 inches tall, 15 to 1 is inches broad 15 to 18 inches tall, 15 to 18 inches broad

Or 18 to $2+$ inches tall, 18 to 24 inches broad 12 to 15 inches tall, 15 to is inches broad

Or 15 to 18 inches tall, 18 to 24 inches hroad 15 to 18 inches tall, 18 to 24 inches broad 15 to 18 inches tall, 10 inches broad

Or 18 to 24 inches tall, 12 inches broad 15 to 18 inches tall, 15 to 18 inches broad Or 18 to 24 inches tall, 18 to 24 inches broad 12 to 15 inches tall, 15 to 18 inches broad Or 15 to 18 inches tall, 18 to 24 inches broad 15 to 18 inches tall, 12 inches broad

Or 18 to 24 inches tall, 15 inches broas 15 to 18 inches tall, 15 inches broad Or 18 to 24 inches tall, 18 inches broad 15 to 18 inches tall, 15 inches broad () 18 to $z 4$ inches tall, $Q 2$ inches broad 12 to 15 inches tall, 12 inches broad

() 15 to 18 inches ta\}l, 15 inches broad 12 to 15 inches tall, 12 to 15 inches broad ( ) $\mathrm{r}^{15}$ to 18 inches tall, 15 to $1 \mathrm{~s}$ inches broad 10 to 19 inches tall, $(i$ to 8 inches broad 10 to 12 inches tall, 8 to 10 inches broad 15 to 18 inches tall, 15 to 1 is inches broad Or 18 to 24 inches tall, 18 to 24 inches broart 8 to 10 inches tall, 8 to 10 inches broad!
“ T H E
S T A N D A R D
O F
Q U A L I T Y
F O R
A M E R I C A," 


\section{Screen Planting}

The planting of shrubs and trees around one's place ean be made to do much more than beautify. For instance, possibly there is an umpretty view from some of your windows, or porch - a cut-away embankment, an unkempt vaeant lot, or the service yard of a neighbor's place with its attendant flapping line of clothes on wash-days. Or perhaps your neighbor is a bit careless and permits refuse to collect in his back yard. If so, the vista from your windows may be something like that shown in sketch No. 6.

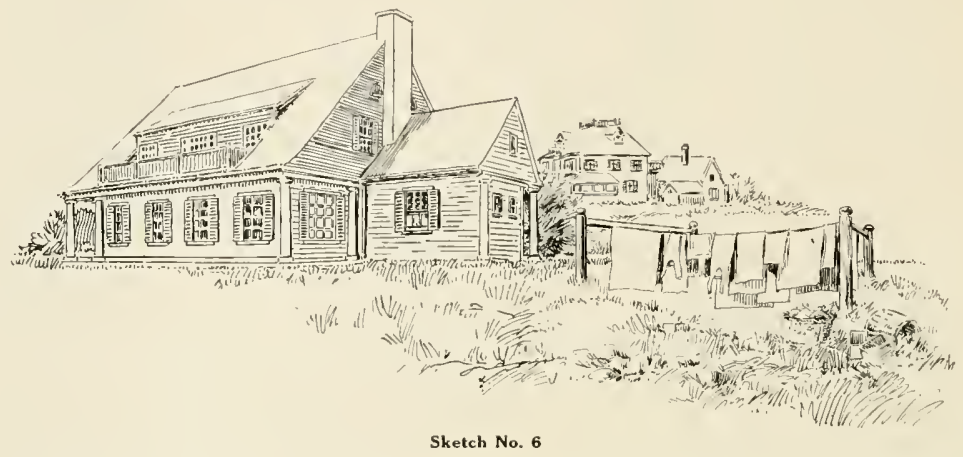

How much more pleasing the view would be if by planting Framingham Nursery stock you were to make it resemble something like Sketch No. 7.

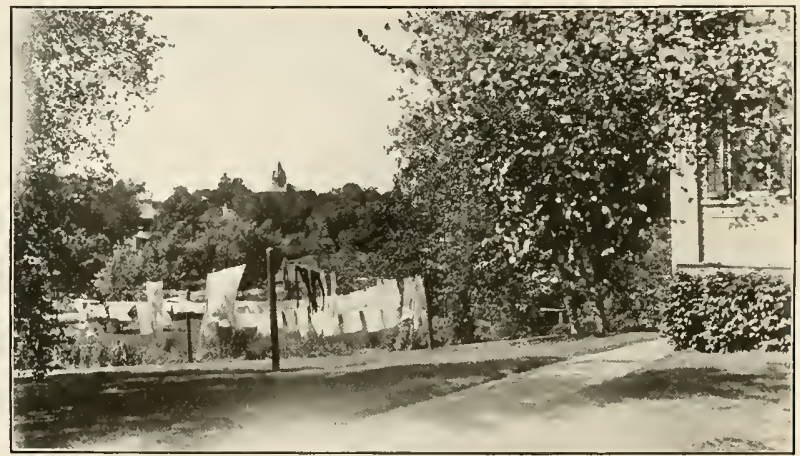

Is there anything attractive in this back yard with its flapping wash? The harmony of surroundings is completely spoiled,

Such a screen is made up very similarly to the way we have already suggested for Foundation planting; using for the back (or outside) row any of the very tall growing shrubs listed on Page 26; with possibly a tree or two to give it point; see Page 28. In the next row (nearer your house) and on the ends of the back row, fairly tall or medium shrubs FRA M I NGHA M N URSERIES-FRA M N G HA M, MA S S. 
may be used. And, as is often desiralble, in front of this a thind row of medium or small shrubs to further soften the lines and break all possible monotony on your side of the screen. This presents an opportunity to use shrubs with fine foliage or bark colorings, as well as flowering shrubs.

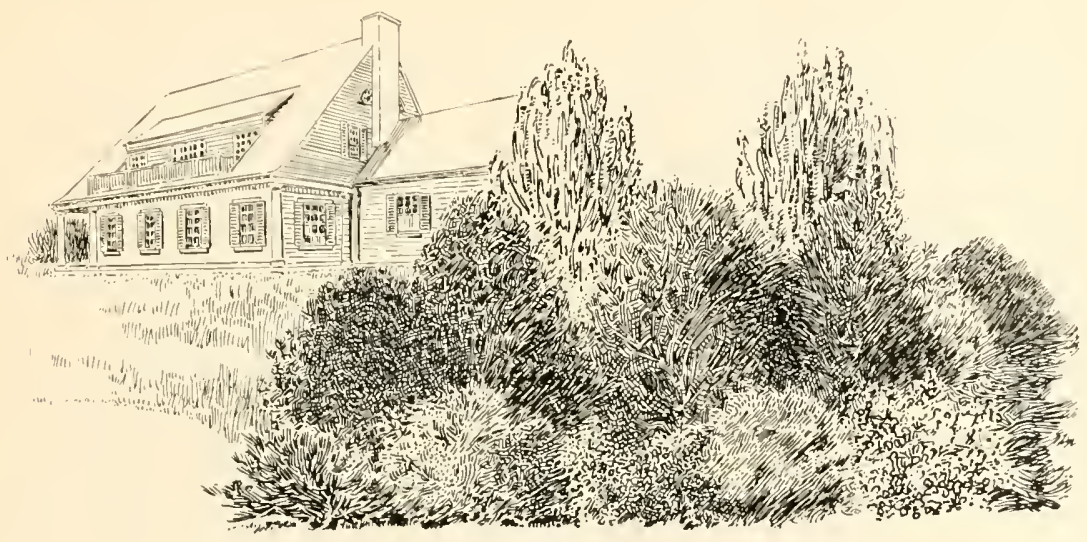

Sketch No. 7

A sereen of Evergreens is also very good for this purpose, and possesses the added adrantage of blocking the view the whole year romd, as is shown on Sketch No. 8.

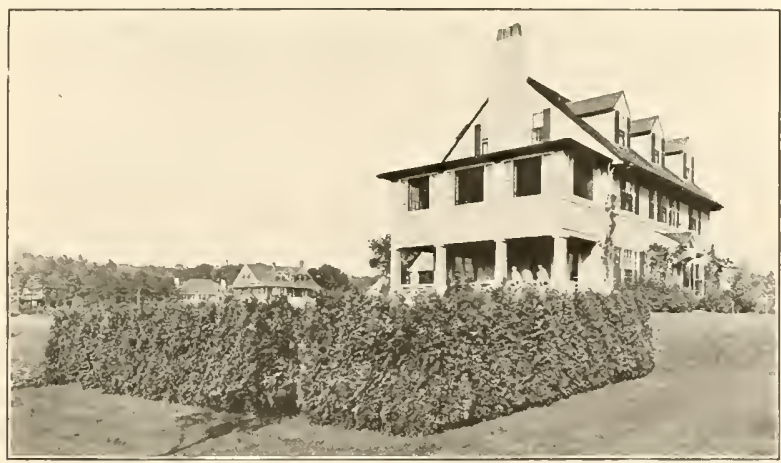

Yet observe how easily and effectively a service-yard mat be screened in stmmer and winter with Framingham evergreens.

Evergreens suitable for this purpose will be found on Page sy.

Or perhaps, in your own back yard - while you do not allow refuse to collect your own clothes yard is exposed to public view. In such case you can improve matters immensely by putting in a shrubbery sereen similar to the one suggesled in Sketch No. 7
“ T H E
S T A N D A R D
O F
Q U A L I T Y
F O R
A M E R I C A " 
or by planting a one-row sereen of dense colummar Evergreens. The latter has two advantages - First, being evergreen, the effeet lasts all year round; even winter's harshest touch eannot lessen it. Second, narrow Evergreens like these do not take up much land space. These eohmnar Evergreens are presented on Page 99.

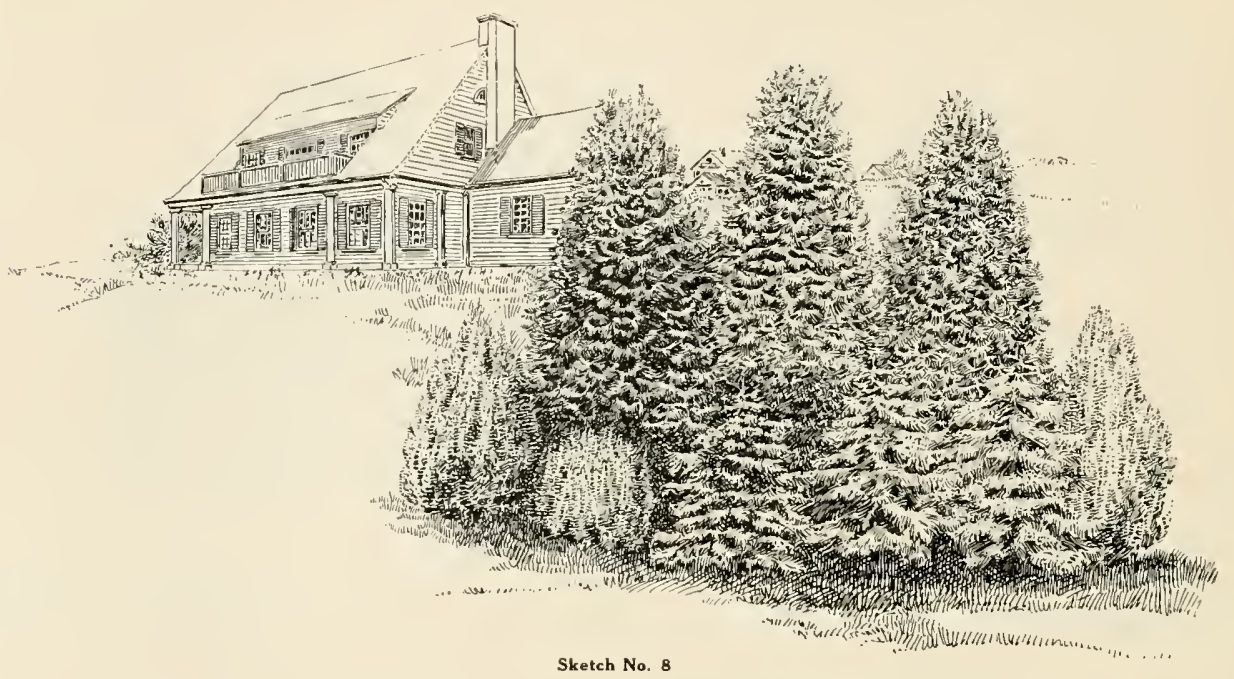

\section{Planting for Seclusion and Privacy}

While serving a slightly different purpose, shrubbery screens planted to bring greater sechision and privacy to a home should be planned and handled in much the same manner as that which we already have suggested for the Screen Plantings described in the foregoing paragraphs.

Your house may be close to your neighbor's. From the windows of the house next door one ean look into your windows, or vice-versa. Lights from the other house or from the street may annoy you on summer evenings. You have not the feeling of sechsion you would most enjoy.

Sketch No. 9 illustrates the remedy.

See pages 26 and 28 for the shrubs suitable for sereening as above.

This planting (of deciduous varieties) is very similar to that shown in Sketch No. 7 - the taller shrubs being nearest your neighbor's and the smaller shrubs toward your own house. The use of deciduous shrubs for a planting such as this is especially good if you go

F R A M I G H A M N U R S E R E S - F R A M I N G A M, MA S S. 
away for a portion of the Winter and ane at hone a considerable part ol the Summer, when the leatres are on. But, if like most of us, you spend more time in yonr lonse during the Winter months, when the leaves are ofl, and are on your vacation during the greater part of the summer season, the more genuinely serviceable type of sereen for you to plant would be one of Livergreens, ats depicted in sketeh No. 10.

The elfect of fallen snow on an Evergreen sercen of this kind is always attractive and cheery. Noreover, if the spot to be planted is North or West of your house, such a

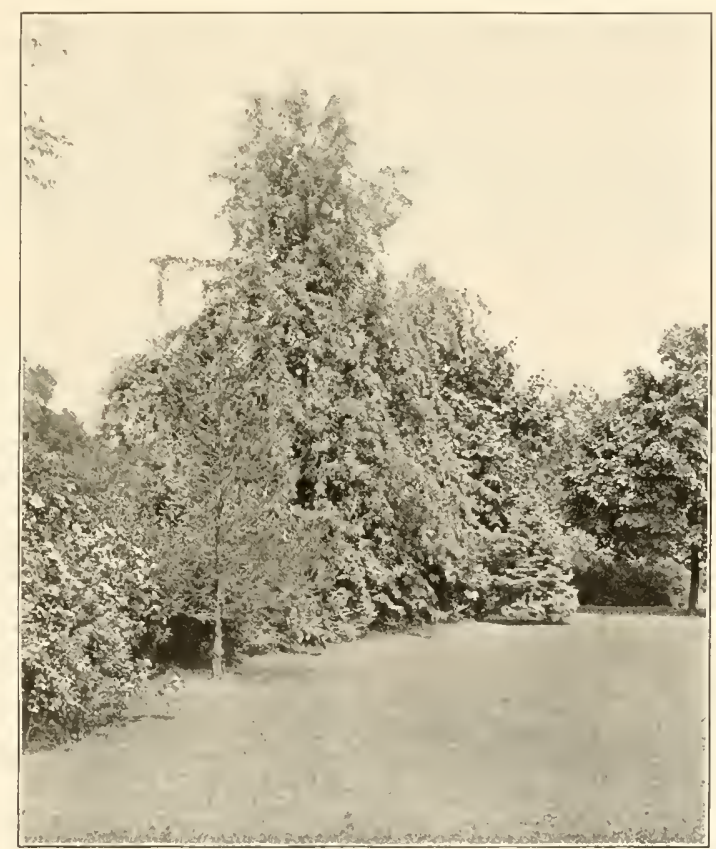

A handsome screen of deciduous trees and large slirubs serving both to beautify and to shut out the view of a neighbor's back yard.

planting will make a very efficient wind-break and provide welcome protection against the driving snow. This type of sereen is also effective in shading out possible amnoyince from street lights ete., all the year round. See page $\$ 9$ for sueh evergreens.

About many homes are shade trees so arranged at the side or rear of house that they could be made into very inviting spots for lunches, teas, suppers, and little parties during the hot summer weather - were it not for the fact that they are more or less open
“ T H E
S T A N D A R D
$\mathrm{O} \mathrm{F}$
Q U A L I T Y
F O R
A M E R I C A " 
to public gaze. Here is an opportunity, then, to utilize such spots by surrounding them with a shrubbery border screen, evergreen hedge, or evergreen border.

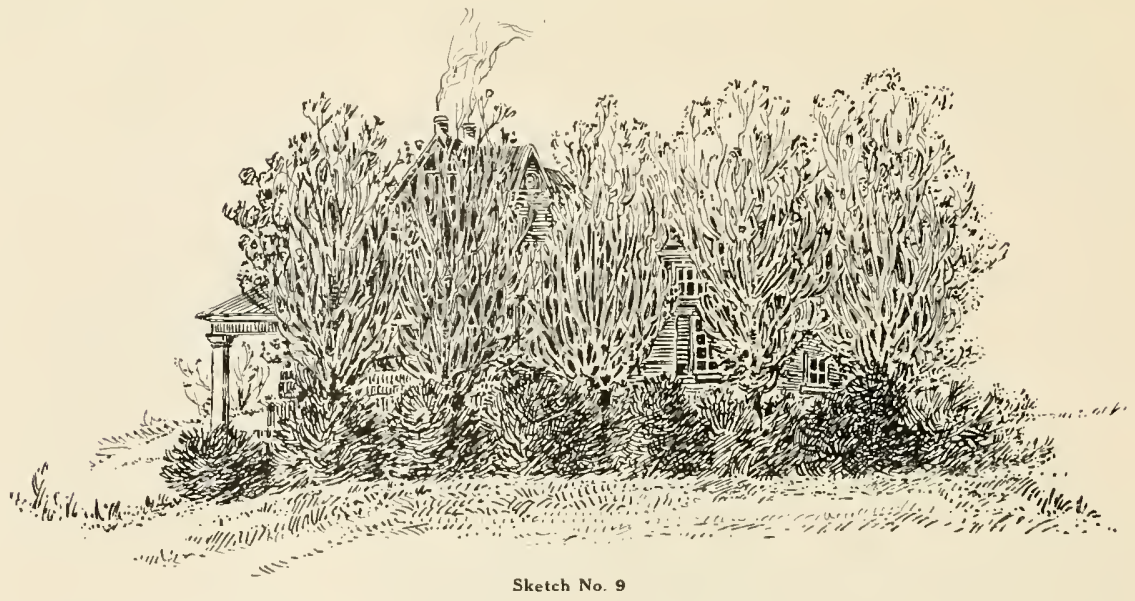

Shrubbery border-sereens are discussed on pages 26 and 28.

Evergreen hedges are discussed on page 34.

Evergreen borders are discussed on pages 29 and 31.

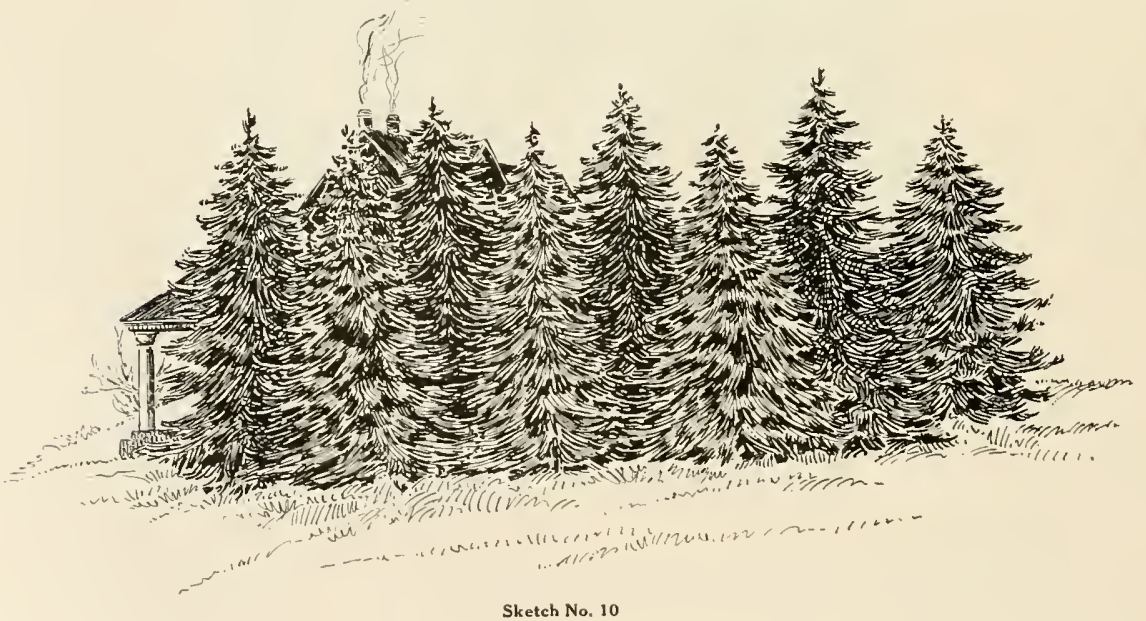

F R A M I N G H A M N UR S E R I E S F R A I N G H A M, M A S S. 
But whatever of this material is used, the result will be approximately like sketch No. 11 .

Such a treatment will afford an artistic and usefully secluded nook, screened off from everybody outside.

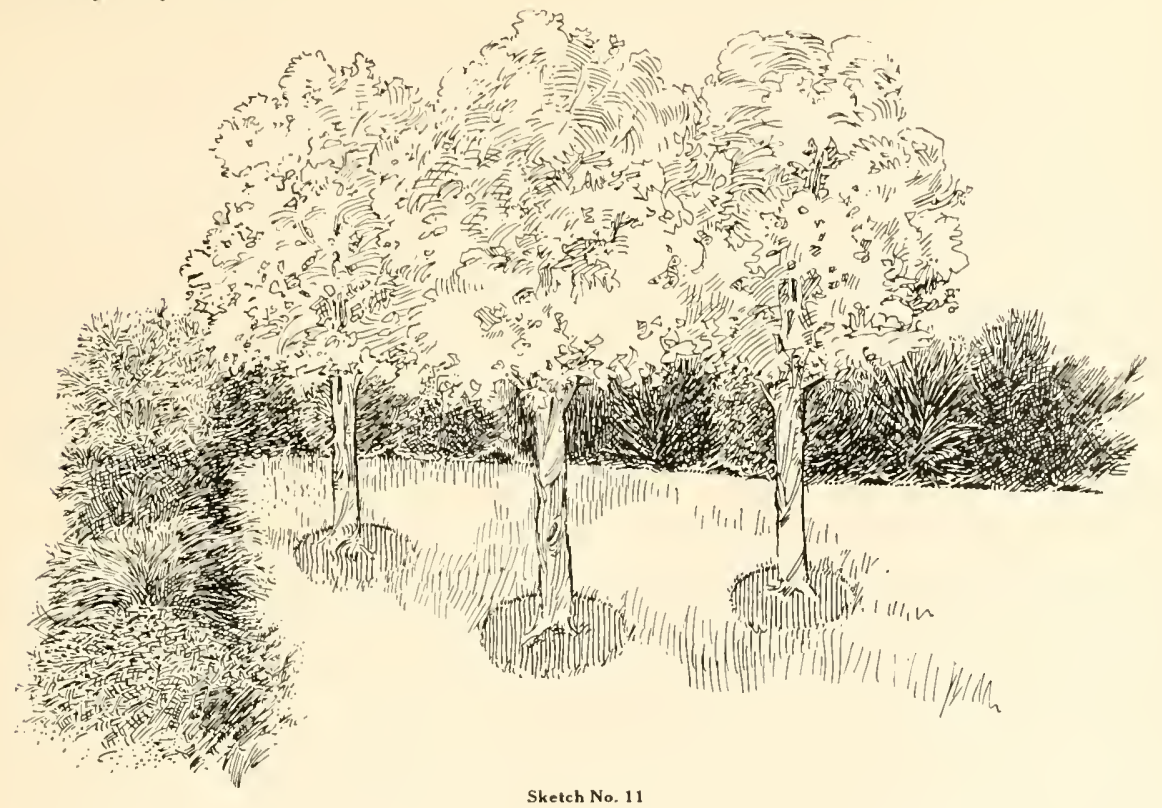

Piazzas, also, can very easily be made more attractive, useful, comfortable and secure against public vision, the glare of lights, and the attacks of wind or weather, by planting any of the Vines listed and described on pages 40 and 4.

Note general planting directions on page 58 - but first of all bear in mind this most important of all rules:- that it is better not to plant at all than to plant cheap inferior stock from some unknown source and be led into disappointment, waste of time and loss of money. The infinite care taken in raising Framingham Nursery stock assures the highest possible quality at a fair price.

“T HE S T A N D A R D OF Q U A I T Y FOR A MERICA " 


\section{DECIDUOUS SHRUBS FOR SCREEN AND BORDER PLANTING}

Plants for this purpose are here classified as in preceding lists: - (1) according to ultimate height, (2) by color of flower, etc. (3) hy common name. Individual heights given in each case indicate size in which plants are now ready for delivery.

Dagger $(t)$ signifies suitability for sea-shore planting.

\section{Varieties Attaining a Height of 15 to 25 feet}

(These varieties should be planted 6 feet apart with smaller shrubs as classified under Foundation Planting for front rows.)

\section{PURPLE FLOWERS}

False Indigo

A mar pha fruticasa

Foliage feathery. Very dark violet purple flowers in spikes 2 to 3 inches long in June, make a very handsome shrub.

\section{YELLOW FLOWERS}

Siberian Pea Caragana arborescens Flowers in June. Bark dark green and foliage very neat. Fruit in small green pods like pea-pods.

Cornelian Cherry Cornus moscula Dense habit. Foliage glossy. Very attractive in March and April with its yellow flowers, and again in the fall with shining, scarlet, edible fruit.

\section{IVHITE FLOWERS}

White Fringe

Chionanthus virginica Foliage large, dark green. Flowers in large panicles 4 to 6 inches long, in May and June, make a very showy shrub. Black grape-like fruit.

Blue Dogwood

Cormus alternifolia Very graceful; branches in whorls. Flowers in late Iay and early June. Dark blue berries find great favor with birds. See page 44 .

Silver Bell

IIalesia carolina Spreading habit. Beautiful, large bell-shaped flowers profusely borne in May give a very distinctive effect

Wayfaring Tree

I'iburnum lantana Foliage large, silvery on under-side. Clusters of flowers in May followed by red fruit turning black in autumn. Atracts birds.

\section{VARIETIES VALUABLE FOR FRUIT EFFECT}

\section{White Fringe \\ Chionanthus rirginica}

Foliage large, dark green. White flowers in large panicles 4 to 6 inches long, in May and June, make a very showy shrub. Black grape-like fruit.

Blue Dogwood

Cornus alternifolia

Very graceful, branches in whorls. White flowers in late May and early June. Dark blue berries find great favor with birds. See page $\mathbf{4 4}$.

\section{Cornelian Cherry}

Cornus mascula

Dense habit. Foliage glossy. Very attractive in March and April with its yellow flowers and again in the fall with shining, searlet, edible fruit. Attracts birds.

\section{Spindle Tree}

Euonymus europae?

Inconspicuous white flowers. Foliage dark, turniug crimson in autumn. Scarlet-orange fruit. Attracts birds. See page 43 .

+Staghorn Sumac

Rhus typhina

Picturesque native shrub. Branches hairy. Large cones of deep hrick red fruit covered with crimson hairs. Ittracts birds.

Wayfaring Tree

J“iburnum lantana Foliage large, silvery on under side. Clusters of white flowers in May, followed by red fruit turning to black in autumn. Attracts hirds.

\section{Varieties Attaining Height of 10 to 15 feet}

(These shrubs should be planted 5 feet apart. Plant smaller shrubs as listed under Foundation Planting for front rows.)

\section{WHITE FLOWERS}

†Groundsel Tree

Baccharis halimifolia Fiffy flowers in September makes this shrub appear as covered with cotton.

Bailey's Dogwood

Cornus bailcyi Tall and comparatively narrow. Blooms nearly all summer. Branches dark red, particularly effective in winter. White berries in fall. Attracts birds.

†Gray Dogwood

Cornus paniculata Creamy white flowers in July. White berries in autumn. Attracts birds.

European Red Osier

Cormus sanguinea Blooms in July. White berries in autumn. Attracts birds.

tArrow-wood

I'iburnum dentatum. Flat flower clusters in June followed by black fruit. Attracts birds.

†High-bush Cranberry

Jiburnum opulus. Flat clusters of flowers in June followed by red berries. Attracts birds.

\section{WHITE FLOWERS, (continued)}

†Amoor River Privet

Ligustrum amurense Small flowers followed by a few black berries in autumn. Tall and rather narrow. Ittractive foliage. Nakes a fine hedge. See page 33 .

Sheep-berry

Iiburnum lentago Flowers creamy white and very iragrant. Foliage light glossy green. Fruit bluish black. Attracts birds.

Common Snowball

Viburnum opulus steritis Round masses of creamy white flowers in early June.

\section{PURPLE FLOWERS}

Smoke Bush

Rhus cotinus

Attractive round leaves. Large numbers of mistylooking grayish purple flowers appear like a cloud of smoke in early June.

Hungarian Lilac

Syringa josikaea Glossy dark leaves. Flowers appear in late June, after other lilacs have faded.

\footnotetext{
F R A M I N G H A M
}
N U R S E R I E S 


\section{DEGIDUOUS SHRUBS FOR SCREEN AND BORDER PLANTING}

\section{VARIETIES VALUABLE JOR BARK, LEAF AND FRUIT EFIEECT}

Bailey's Dogwood

Cornus baileyi

White flowers nearly all summer. Branches dark red, very" affective in winter. White berries attract birds.

Pink-fruited Spindle Tree

Euamymus bungeand Pruit pink, opening so as to show its red sereds. Vory showy. Itlracts birls.

tinglish Privet

Ligustrum rulgare small white fowers followed by large clusters of sliny black sluowy fruit. Valuable hedge plant. See page 3:

Purple-leaved Plum

Prunus pissurdi Insignificant pink flowers. Valuable for its deej purple leaves which retain their color until late in the falt.

†Buckthorn

Rihamnus cathartica

Foliage dark green, branches sping. It raclive small black fruit. Cood hedge plant. Sec page 39 .
Carolina Buckthorn

Rhamnus caraliniann Leaves dark green turning to yellow orange and red. Red berries turn black in fall. Ittracts birds.

tSmooth Sumac

Rhus glabra

Bark smooth. Very striking in autumn witl its deep brick red seeds and crimson leitves.

Tiburnum dentalum Flat white clusters of flowers in June followed by black berries which attract birds.

Sheep-berry

J'iburmum lentagn

Flowers creamy white and very fragrant. Foliage light glossy green. Fruit bluish black. Aftraets birls.

†High-bush Cranberry Tiburnum opulus What white clusters of flowers in June followed by real berries. Attracts birds.

\section{Varieties Attaining Height of 6 to 10 feet}

(Should be planted about + feet apart with smaller sbrubs as listed under Foundation Planting, for front rows).

\section{RED FLOWERS}

Red Tartarian Iloneysuckle

Lonicura tatarica grandiflora rubra A variety of the well known honeystekle. Flotwers are red with orange yellow center in June. small red fruits somewhat showy.

\section{PINK FLOWERS}

†Common llydrangea IIydrangea paniculata grandifiora Large cone-shaped flowers are white early in .Iugust, turning to deep pink shortly afterward.

†Tartarian Honeysuckle

Loniccra tatarica Profusion of small flowers in June. Light red fruit.

Large-flowered Honeysuckle

Lonicera tatarica grandiflora rasea Similar to preceding. Flowers larger.

Rosa Acacia

Robinia hispida Beautiful rose colored flowers in May and June. Very fine when in bloom.

\section{VELIOW FLOWFRS}

+Common Barberry

Berberis vulgaris Golden Yellow flowers in June and brilliant red berries in autumn.

\section{†Siberian Dogwood}

Cornus siberica Small flowers in June. Large handsome leaves, Blood red stems contrast well against snow.

Burning Bush

Euomymus alate Flowers small in May and June. Wood corky. Smootl foliage turns into a mass of flame in lall. Jears a few red berries. Very symmetrical.
†Green-twigged Golden Bell Forsythia viridissima Abundant flowers in early May. Bark, green.

Yellow Flowered IIoneysuckle Loniccratatarica allida Blooms May and June.

†ragrant Sumac

Rliks aramatica Small flowers in eariy May. Leaves aromatic, turning deep crimson in fall.

\section{PURPLE FLOWERS}

Common Lilac Syringa vulgaris Large flowers abundant in May. Leaf heart-shaped, dark green.

\section{WHITE FLOWERS}

Button Bush Cephalanthus occidcntolix Dense ereamy-white flowers from July to September.

tSilky Dogwood

Cornus sericce Flowers in June and July. Jhe berries in October. Stems redlish.

American Red Osier

Cornus stolanifera Flowers in June. Blood red stems attraetive against snow.

Pearl Bush

Exochorda grandiflora Large lone elusters of flowers in $\mathrm{Nay}$

White Tartarian Iloneysuckle Loniecra taturica grandiflora alba Flowers in Mlay and June.

Elderberry Sambucus canadensis Broad flat clusters of flowers in June and July, followed by black berries in september from which a fine wine can be made. Berries attract birks.
“ T H E
S T A N D A R D
O F
Q U A L I T Y
F O R
A M E R I C A", 


\section{WHITE FLOWERS}

Golden Elderberry Sambucus nigra aurea Similar to preceding. Leaves golden yellow. Good for dusty places.

Common White Lilac Syringa vulgaris alba Large flowers abundant in May. Leaves heart-shaped, dark green.

+Blueberry Taccinium corymbosum Small urn-shaped, waxy flowers sometimes tinged witb pink. Blue-black edible berries in July. Brilliant searlet leaf effect in autumn.

Single Japanese Snowball

Jiburnum tomentosum Flowers 2 to 3 inches broad in June. Fruit red turning to blaek.

\section{VARIETIES VALUABLE FOR BARK, LEAF OR BERRY EFFECT}

†Red Chokeberry

Aronia arbutifolia

Red berries and erimson leaves in autumn. Attraets birds. See page 43 .

Black Chokeberry

Aronia melanocarpo Black berries in fall. Attractive to birds. See page 43

Bush Aralia

Iralia pentaphylla Beautiful dark green, five-lobed leaves which remain on spiny stems late in fall. Ineonspienous yellowish green flowers.

tCommon Barberry

Berberis vulgaris Golden yellow flowers in Spring. Crimson berries whieh attract birds remain on stenss in fall and most of the winter. Foliage red in fall

†Purple-leaved Barberry Berberis vulgaris purpurea Similar to Common Barberry. Leaves purple. Fruit purple.

Siberian Dogwood

Cornus siberica Small yellow flowers in June. Large handsome leaves. Bark is brilliant red during winter. Fine contrast against snow.

†Silky Dogwood

Cornus sericea

White flowers in June and $\mathbf{J u l y}_{\mathrm{l}}$. Blue berries in October. Stems reddish.
American Red Osier

Cornus stolonifera White flowers in June. Blood red stems attractive against snow.

Yellow-stemmed Osier

Cornus stolonifera lutea Bright red stems make it very showy after leaves fall. Contrasts well against red stemmed varieties.

Burning Bush

Euonymus alatu Small yellow flowers in May and June. Smooth leaves turn brilliant red and orange hues in fall, making a mass of flame. Bears few red berries. Very symmetrical grower.

Winter Berry

Ilex verticillato Very bushy. Branehes upright. Foliage light green. Iolds its searlet berries until midwinter. Attracts birds. See page 44

Chinese Cherry

Prunus tomentosa Stens covered witl small pink blossoms in May before leaves appear. small edible cherries borne in abundance. Attracts birds. See page 13.

Fragrant Sumac Rhus aromatice imall yellow flowers in early May. Aromatic leaves lurn dark erimson in autumu.

E1derberry

Sambucus canadensis Broad flat clusters of white flowers in June and July. Black berries in September from which a fine wine can be made. Ittracts birds. See page 4.

Golden Elderberry

Sambucus nigro aureo Similar to the preceding. Leaves golden yellow. Valuable for dusty places.

†Ninebark

Spiraea opulifolia Shaggy bark. Most rapid growing shrub we list. Valuable for quick results.

†Golden Ninebark Spiraea opulifolia aurea Similar to preceding. Leaves yellow. Good for dusty places.

†Blueberry

Yaccinium corymbosum Urn-shaped white flowers, tinged with pink in June. Bluish black edible berries in July. Brilliant scarlet fall leaf coloring.

\section{Deciduous Trees for Screen Plantings}

The two following varieties are the best for this purpose. Although not long lived they are rapid growing and give quiek results.

It is often advisable to plant these trees between small evergreens planted for sereen purposes. By the time the evergreens have grown large enough to be effective, these trees have eome to the end of their usefulness and can be removerl.

Carolina Poplar

Pyramidal in form. Bark grayish green. Foliage heart-shaped, bright green. Ilso valuable for shade. See page 39.

Lombardy Poplar

Populus fastigiato

A tall tree. Branehes grow upright and form a narrow tree giving very little shade. We grow this variety leaving the lower branches on, thus making a tree which will make a screen near the ground as well as near the top. Leaves light green. 


\section{Evergreens for Screen Planting}

'This purpose repuires the use of the larger sizes (5 to 6 foet or 6 to 7 feet, or even larger in the back row) for quiek efleet. Sizes listed under "Fomdation l'lanting" may" also be used liere for the front rows, making a border planting.

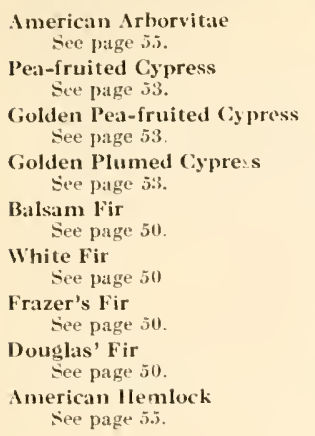

Thuya occidentalis aurea
Retinispora pisifera
Retinispora pisifera anrea
Retinispora plumosa aurea
Abies balsamea
Abies concolor
Abies fraseri
Psenulotsuga taxifolia
Tsuga canalcnsis
Red Ciedar Sce pitge 51.

Austrian pine

See page 52.

Jack Pine

See page 5\%.

Whlte Pine

sice page 53.

White spruce Set paige 51.

Engleman's Spruce

sec page 52.

Norway Spruce

Siec page $5 \%$.

Colorado Green Spruce

See page $5:$.

Koster's Blue Spruce see page 52 .
Juniperus virginiana

Pinus austriaca

Pinas divaricata

Pinus strobus

l'icca alba

Picea engelmanni

Piceu excelsu

I'icea pungens

Picca pungens kosteriana

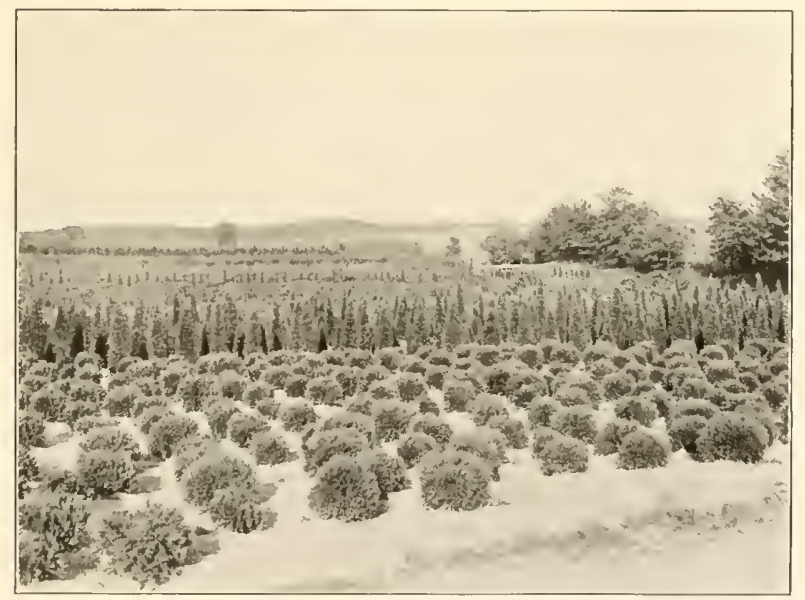

A field of evergreens at the Framingham Nurseries, In foreground are smaller kinds suitable for fousdation and border planting. In background some of the columnar varieties listed below.

\section{Evergreens for Service-yard Screens}

American Arborvitae

Narrow cone or columu. Densely branched. Thrives in ordinary soils.

Peabody's Golden Arborvitae

A variety of the preceding with yellow foliage.
Thuya necidentalis

Thuya occidentalis aurea

Thuya occidentalis puramidalis Pyramidal Arborvitae

Very narrow cone or column. Dense and compact. Foliage rich dark green which does not change appreciably in winter.
“T H E
S T A N D A R D
O F
Q U A L I T Y
F O R
A M E R I C A " 


\section{Wind Breaks}

Following along this subject, we natmrally reach the more specific use of shrubbery for Wind Breaks.

Are the cold, penetrating winds of Winter permitted to rush with unbroken force against your house from the north and west? If so, it may le that not infrequently you are forced to inconvenience and considerable unnecessary expense in keeping your home at a comfortable temperature. Also the snow is apt to be blown about the house in ungainly, troublesome drifts, covering paths and giving a generally forlorn, bleak appearance to the entire place - something as is pictured in Sketeh No. 12.

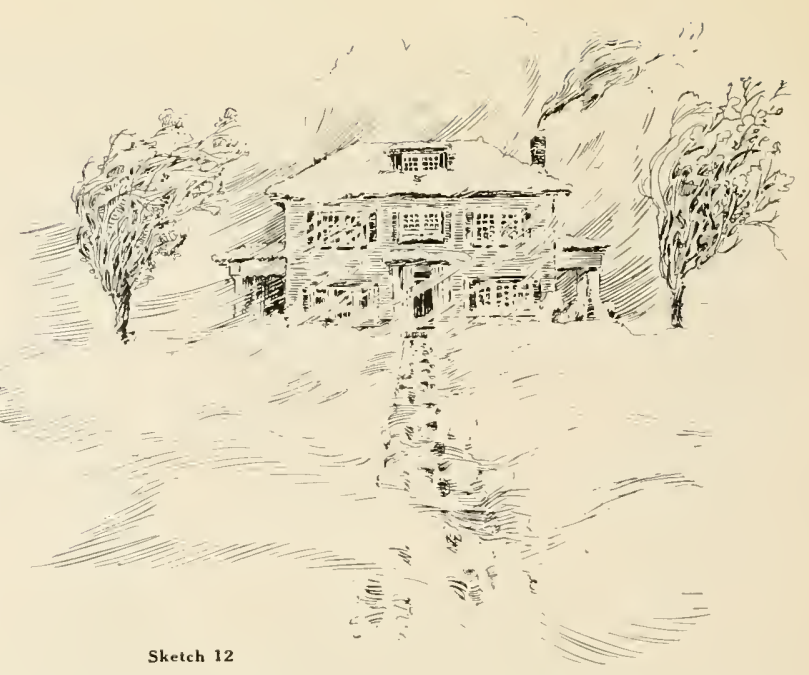

If such is the case, it is entirely unnecessary. There is a very simple but certain preventive available. Plant a high hedge, or W'ind break, of Framingham Evergreens, as shown in Sketch No. 13.

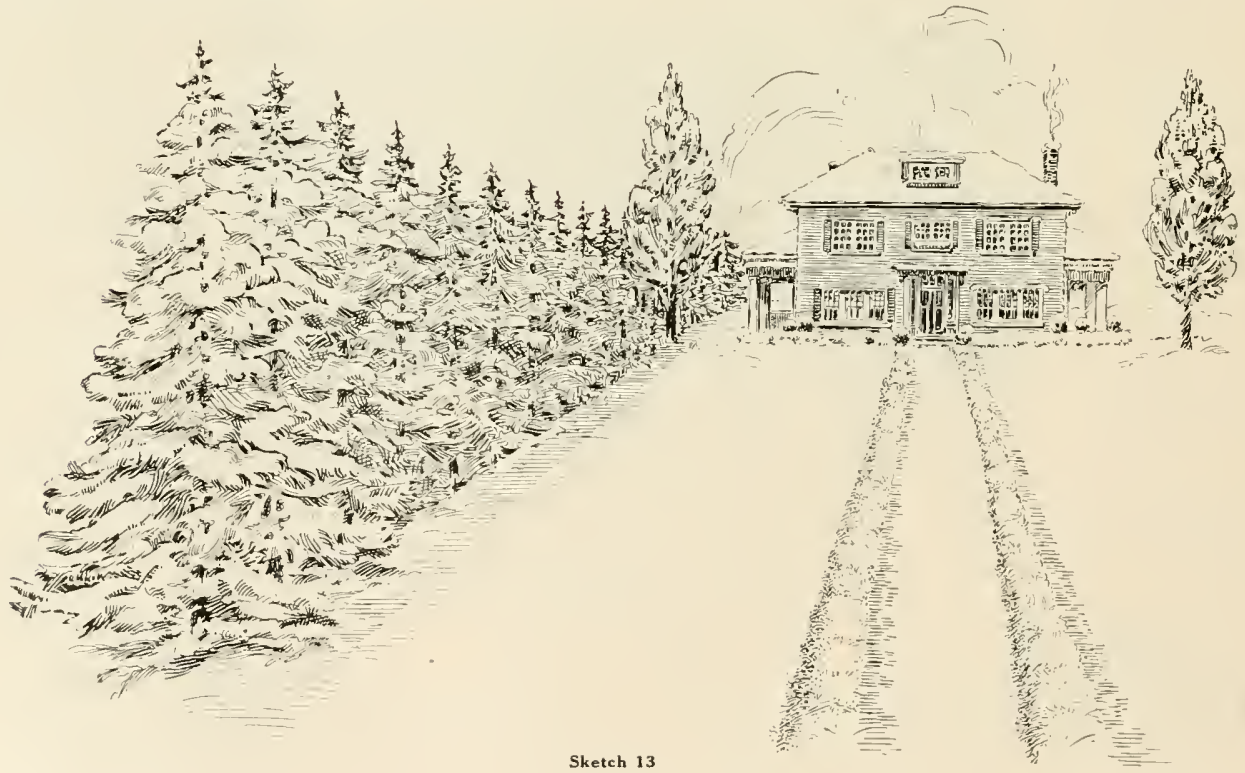

F R A M I N G H A I N U R S E R I E S - F R A M I N G HA M, M A S S. 


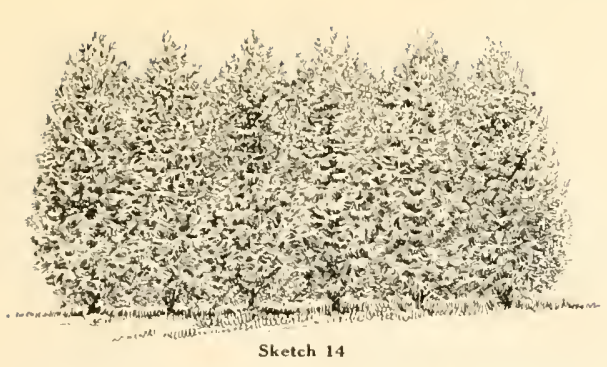

If a close, dense liedge is desired, plant the Evergreens in a single line so that their branches intermingle as in Sketeh No. 14.
'Then, to give a reat, semi-formal eflect, trim off the tops and sides like this:-

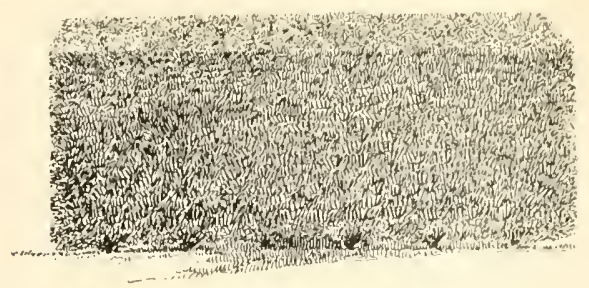

Sketch 15

This type of Windlureak shonld besheared smooth once a year.

Or, if you prefer a more informal Windlureak, plant the Evergreens in a staggered row as in Sketch No. 16.

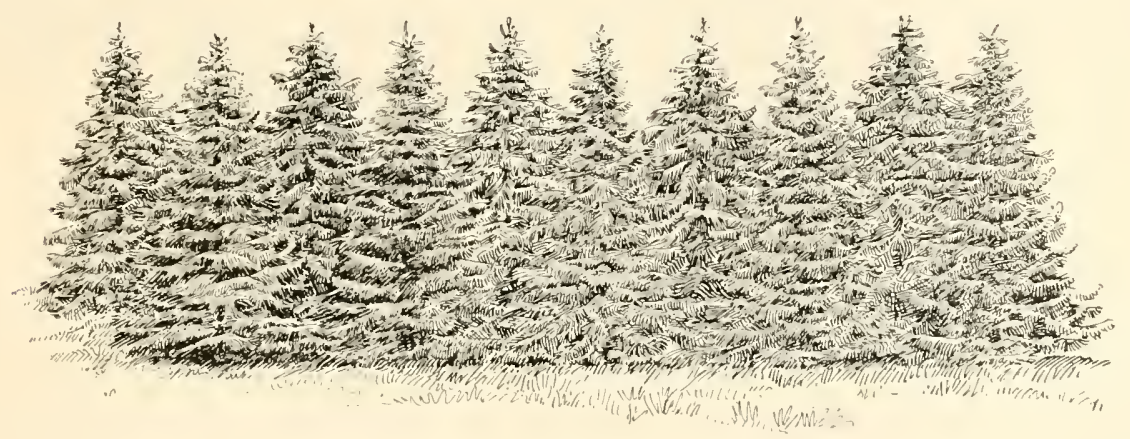

Sketch 16

It is really astonishing what in annomit of improvement ean be effected by following either of these snggestions for Windbreak planting. The house is kept snugger and more comfortable, and the strrounding grounds comparatively free of tromblesone snow drifts.

The most satisfactory windbreaks are made from Evergrcens, as they retain foliage all winter long. On account of the fact that deciduous trees and shrubs lose their leaves in the Fall, their value for windbreak purposes is so small that we shall not discuss them in this connection.

Windbreaks may be made in either of two ways.

1. In informal planting, preferably of at least Lwo staggered rows. Trees should not be trimmed, but left to grow naturally. The varieties mentioned on page 29 for Evergreen Screen Plantings are suitable for this purpose.

2. Large hedges. This makes a closer windbreak and is more suitable for small house lots. The following varieties are best for this purpose, should be planted very close so that the branches intermingle.
Norway Spruce

Iicea excelsa

Broad pyramid, graceful, Rapid growing, attains 75 feet. Foliage dense, dark green. Very successful in cold elimates.

5 to 6 feel, tall, should be planted $\&$ feet apart center to center.

6 to 8 feet tall, should be planted $21 / 2$ feet apart.

8 to 10 feel lall, should be planted 3 feet apar.

American Arborvitae

Thuya occidentulis

Narrow cone or column. Densely branched. Thrives in ordiuary soils.

i) to 6 feel tall, should be planted 21 inches apart center to center.

6 to 7 feet tall, plant $\$ 4$ inches center to center.

7 to $\mathrm{s}$ feet tall, plant 97 inclees apart center to center.

“THE S TANDARD OF Q UALIT Y FOR A II ER I G A " 


\section{Protective Plantings}

People who live near a sehool house invariably experience the annoyance of having the ehildren walk along the edges of their lawns and wearing away the grass. Or where a house is on a much-used street, not only children but the grown-up passers by are more than frequently guilty of the same thing. In such cases the use of wire wickets or other sueh deviees generally proves but temporary in its effeet. A hedge is the proper remedy. No. 18.

A hedge may be either formal or informal, as illustrated in Sketches No. 17 and

Hedges - formal and informal - ean be made of the deeiduous shrubs below and on Page 34; or of the Evergreens, deseribed on Page 34. Varieties marked with dagger $(\dagger)$ are suitable for seashore planting.

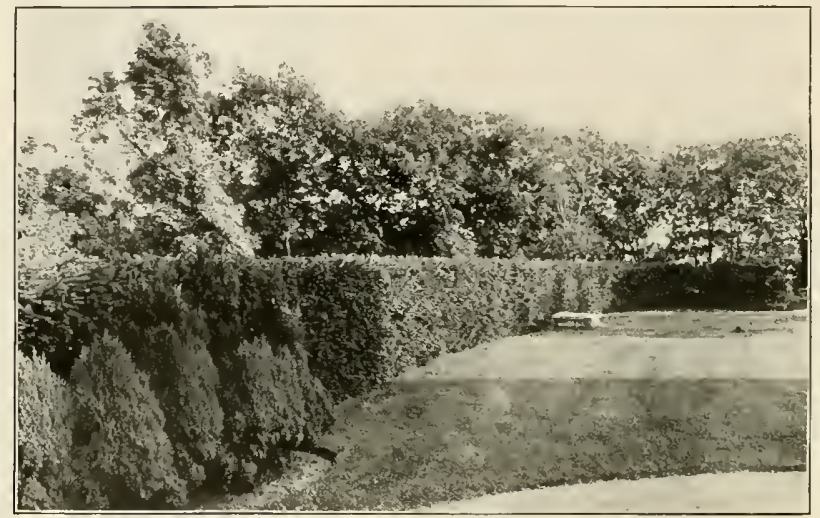

This sturdy evergreen hedge of Norway Spruce does much to give privacy, dignity, and distinction to the estate on which it is planted.

\section{Hedges}

\section{Deciduous Shrubs for Hedges}

$\dagger$ Japanese Barberry

Small, slow-growing, spreading; branchlets drooping. Makes a dense round, broad hedge, which, on account of its thorns is never molested by dogs or children. Leaves small, round, turning scarlet in autumn. Bears quantities of crimson berries which remain until late winter. Attracts birds. Can be trimmed into any shape. Sbould be planted every 12 inches.

†Cockspur Thorn

Crataegus crus-galli Handsome dark glossy leaves. Stout thorns 2 inches and more in length. Makes a positive barrier to trespassers. Should be planted every 24 inches.

\section{California Privet}

Ligustrum oralifolium

The best known of all hedge plants. Leaves dark green and shining. Makes a tall narrow hedge which can be made broader by severe pruning. Somewhat tender, but worth planting on account of its great beauty.
tChinese Privet

Ligustrum ibota The hardiest and most graceful of all privets. Makes a broad hedge of medium height and withstands shearing perfectly. Plant every 12 inches.

†Regel's Privet

Ligustrum ibota regelianum Similar to the preceding bu broader and shorter. Plant every 15 inches.

†English Privet

Ligustrum vulgare Iakes a broad, tall hedge. White flowers in June followed by large clusters of shiny black berries. Plant every 12 inches.

†Buckthorn

Rhamnus catharica

Foliage dark green. Branches spiny. Attractive small black fruit. Plant every 18 inches.

F R A M I N G H A M

N U R S E R I E S
F R A M I N G H A M,
M A S S. 


\section{HEDGES}
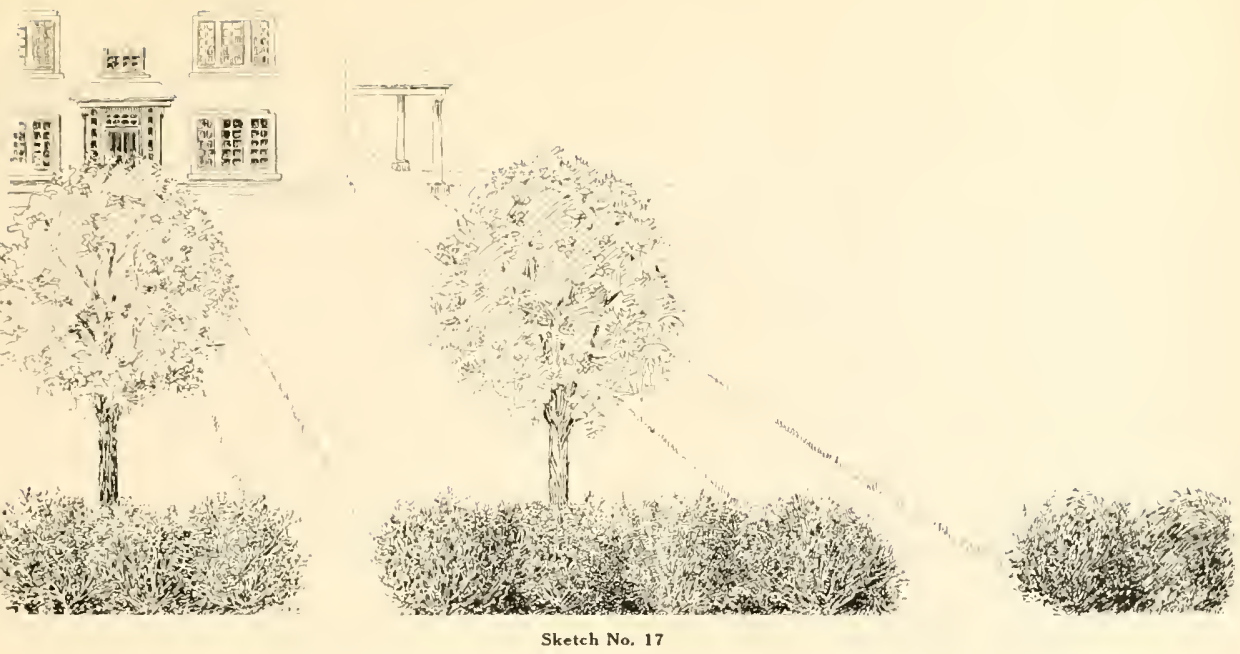

INFORMA IIEDGE, the shrubs left to grow naturally.

1) $m=1$ 间
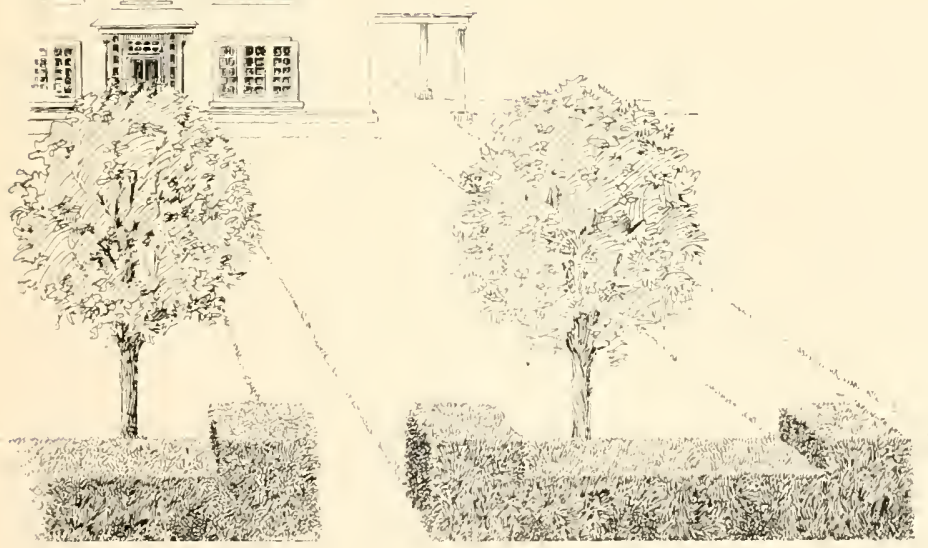

Sketch No. 18

Formal IEDge, made by trimming the tops and sides.
“T H E
S T A N D A R D
O F
O U A L I T Y
F O R
A M E R I C A" 


\section{Flowering Shrubs for Hedges}

Japanese Quince

Cydonia japonica

link flowers in March and April. Compact and dense. Branches thorny. May be allowed to grow large or ean be kept small by pruning which does not affect the bloom. Plant 15 or 18 inches apart.

Maule's Japanese Quince

Cydonia japonica maulei

Similar to preceding. Flowers yellow orange. Plant every 15 incbes.

\section{Red Japanese Quince}

Cydonia japonica umbilicata

Similar to Japanese Quince. Flowers red. Plant every 15 inches.

\section{Lemoine's Deutzla}

Deutria lemoinei

Pure white single flowers in large clusters. Completely cover the shrub in May and June. Grows up to four feet tall and four feet loroad. Makes a round hedge which needs very little trimming. Plant every 18 inches.

†Japanese Rose

Rosa rugosa

Foliage glossy dark green. Flowers single red, fragrant June to December. Sitems densely covered with slender thorns. Large bright scarlet fruit in fall and winter attracts birds. Especially adapted to seashore planting. I'lant every 15 to 18 inches.

†White Japanese Rose

Similar to preceding. Flowers white. Plant every 15 or 18 inches.

\section{†Everblooming Spiraea}

Covered with pink flowers in flat panicles in July and August. Makes a low hedge which eannot be trimmed smooth without hurting the bloom. Plant every is inclues.

\section{†Crimson Everblooming Spiraea}

Spiraea bumalda Anthony II aterer

Similar to the preceding. Flowers crimson. Plant every 18 inches.

\section{Evergreens for Hedges}

\section{American Arborvitae}

Thuya occidentalis

Narrow cone or column. Densely branched. Makes a tall hedge ultimately, but can be kept back for years, if desired, by shearing.

3 to $\$$ feet, plant every 15 inches.

4 to 5 feet, plant every 20 inches.

5 to 6 fcet, plant every 25 inches.

Globe Arborvitae

Thuya occidentalis globosa

Low, slow-growing, dense, globe-shaped. Foliage bright green; bronze in winter.

15 to 18 inches, plant every 15 inches.

18 to 24 inches, plant every 18 inches.

\section{Irish Juniper}

Juniperus communis hibernica

Very narrow column. Dense. Foliage light grayish green. Makes a tall and very narrow hedge.

3 to 4 feet, plant every 12 inches.

4 to 5 feet, plant every 15 inches.
Siberian Arborvitae

Thuya occidentalis siberica

Broad cone. Very dense and bishy. Foliage dark steel-gray green. Extremely hardy on a wide range of soils. Makes a broad hedge of medium height which withstands hard shearing.

2 to $21 / 2$ feet tall, plant every 14 inches.

$21 / 2$ to 3 feet tall, plant every 18 inches.

3 to 4 feet, plant every 24 inches.

\section{Norway Spruce}

Picea excelsa

Broad pyramid, graceful. Rapid growing but may be kept comparatively small, if desired, for many years by shearing. When it does finally grow tall it is valuable as a windbreak.

$z$ to 3 feet, plant every $\mathbf{I} 5$ inehes.

3 to $\&$ feet, plant every 20 inches. 


\section{Shade Planting}

Iiter the necessary foundation, sereen, and protective plantings have been properly aceomplished, it is generally diseovered that a bit of shade aloout the homse, at varions points on the lawn, would he weleome. The inviting presence of well-formed shate 'Trees is always an appreciable acklition to the dignity and impression of any gromols; and such trees grow to become almost as well known liends.

'The location of the house in respect to the street governs to great extent the placing of Shade 'Trees.

Where the house is on the north side of the street and close to it, Sketch No. 19 illustrates a good plan to follow in setting out sharle trees:

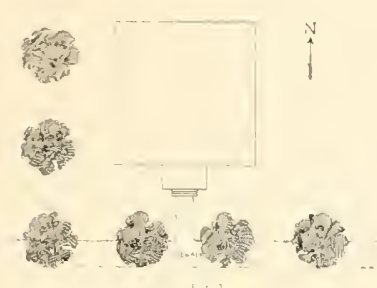

Sketch No. 19

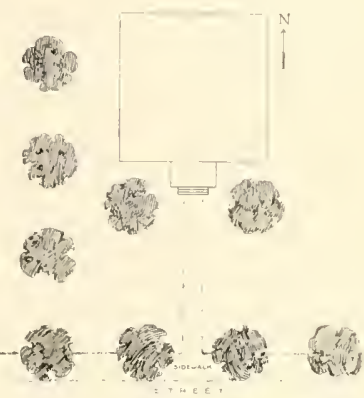

Sketch No. 20

The row of trees on the west side block out the tiring rays of the afternoon sun. Where the house is some distance from the street, trees near the house will shade it while trees near the street not only dignily and dress the grounds, but afford comfort to passers by as well as providing a partial sereen against dust, ete., as in Sketch No. 20.

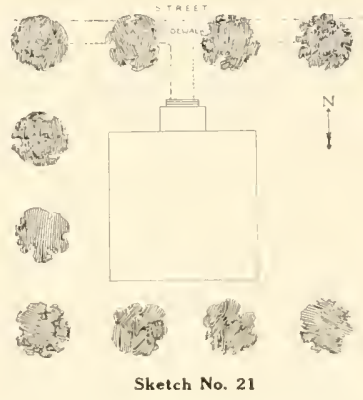

When the house is on the south side of the street, an arrangement such as in Sketeh No. 21 is good. 
The row of trees next to the street, although not shading the louse, shacles the side walk, acts as a dust screen, and also gives the house a good setting - as in Sketch No. $22:-$

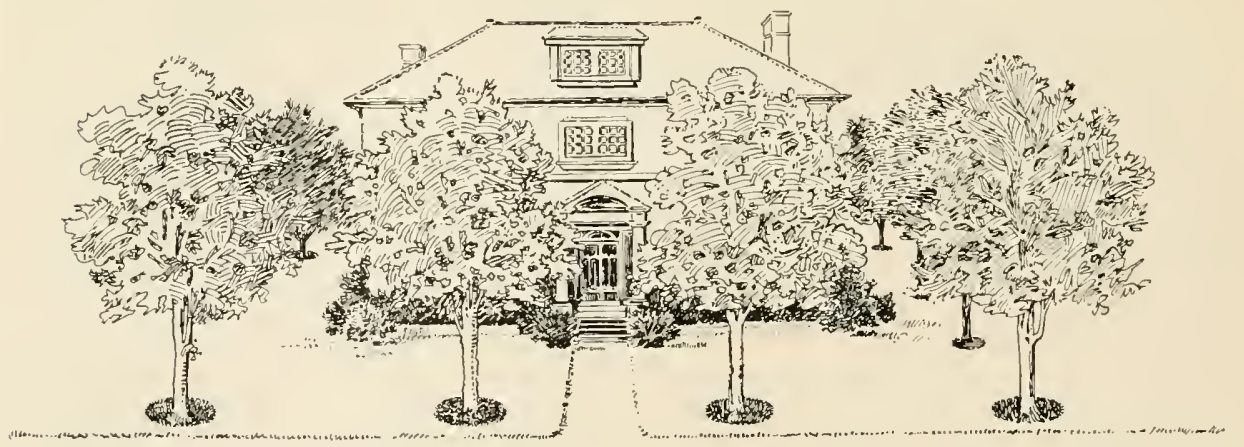

Sketch No. 22

When the house is on the east side of street, Sketch No. 23 (as follows) applies:-

If the house is on the west side of street, the same general plan as laid down in Sketch No. 23 applies - but reversed to correspond with change of position.

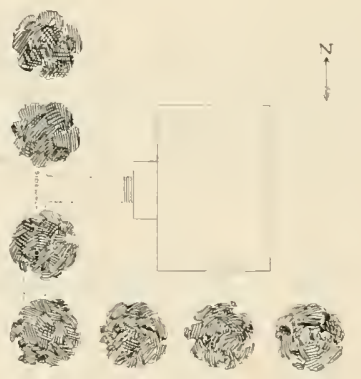

Sketch No. 23

Other trees may be added on the north and east (or west if house is on west side of street) which, while not shading the house, will balance the planting, further dress the grounds, is well as shade the lawn.

Shate trees are listed and cliscussed on Pages 37 and 39. In selecting, all that is necessary to do is to consult the rule of distances given there, in relation to the spaces to be planted.

These trees should be planted from 30 to 40 feet apart. If trees are already planted on part of your street, conform to the distances between the trees already planted.

F R A M I G H A M N UR S E R I E S F R A I N G HA M, MA S S. 
Where trees are to be planted abont the honse, they may be planted as near as wo feet apart. The distance apart shomlel be partly defemined hy the parts of the homse or lawn you desire to shade. By planting go feet apart immodiate sharde is provided. Is trees grow larger, exery other we may he removed.

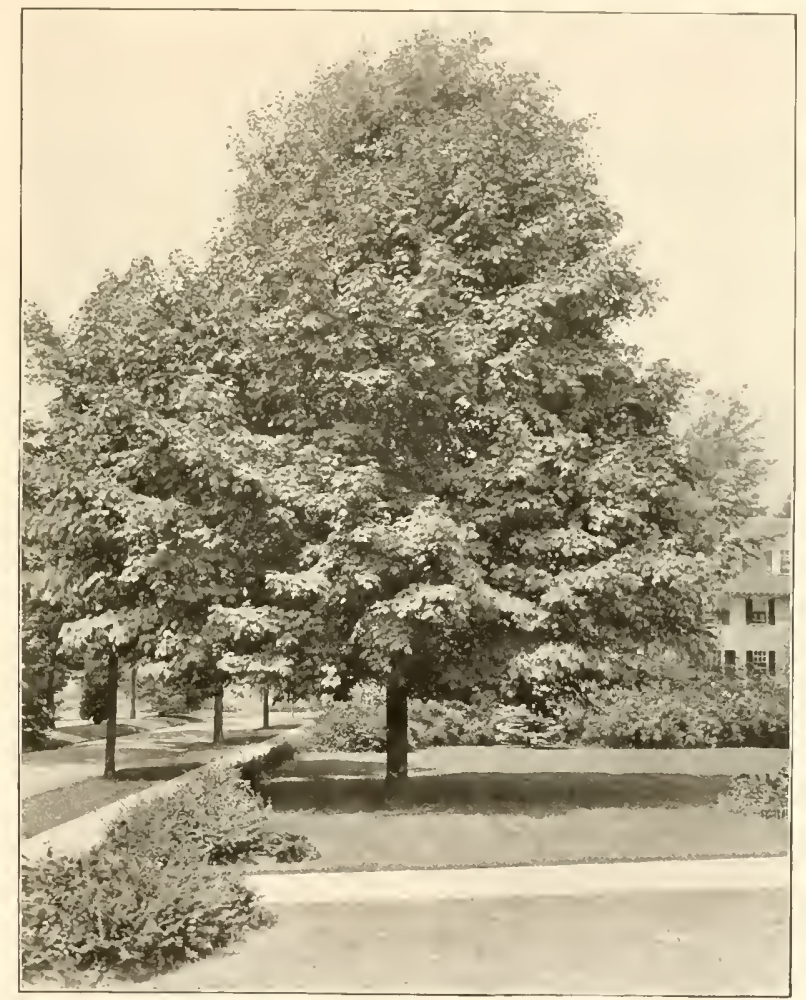

The cool, inviting shade of the Sugar Miple.

Trees like this grow to be real friends.

\section{Shade Trees}

* Varieties marked with a star are those hest suited for street planting.

\section{Silver Maple}

Foliage light green, silvery beneath; most rapid-growing Iaple, hardy; largely used for street planting.

\section{*Norway Maple}

Acer platanoides

A large, handsome tree, wilh round, spreading head; broad, dark green foliage; very hardy. Especially: adapted for street and seashore planting.

\section{Red, or Swamp Maple}

Exeellent habit. Sicarlet flowers in early spring; dense foliage, gorgeous color in autumn.
* Sugar Maple Excellent street and shade Lree, upright and dense growth; foliage lurning bright yellow and searlet in autumn. Does well in almosi every soil.
“ T H E
S T A N D A R D
O F
Q U A L I T Y
F O R
A M E R I C A", 
llorse Chestnut

Aesculus hippocastanum

Large tree of regular outline. Blooms in May; flowers white, tinged with red, growing in panicles 8 to $10 \mathrm{in}$. long; very showy.

\section{Double White-flowering llorse Chestnut}

Acsculus hippocastanum flore plena alba

Double flowers; white and pink, in larger panicles than the Hippocastanum; bears no fruit.
Red-flowering Horse Chestnut

Aesculus rubicunda Very desirable and attractive variety; the foliage is dark; flowers red; lighly ornamental.

\section{European White Birch}

Betula alba

Graceful tree, with spray-like branches and silvery bark; very effective in winter; assumes an elegant. drooping habit.

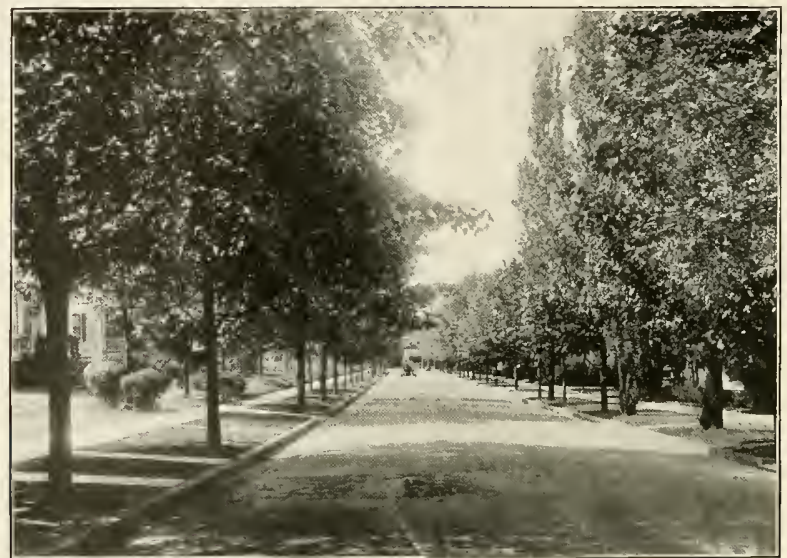

A street well planted with a variety of shade trees. Few things will do more to improve the appearance and value of residential real estate. Photo by courtesy of the House Beautiful Pub. Co., Inc.

\section{Weeping Cut-leaved Birch}

Betula alba laciniata One of the most popular of the weeping trees. Foliage deeply eut, drooping in the most pieturesque manner; silvery white bark; vigorous growth

\section{Black Birch}

Betula lenta

Trunk dark reddish brown; young bark aromatie, with agreeable flavor; handsome round-headed pendulous branches when older; attractive in spring, with its long staminate eathins; leaves heart shaped.

\section{Yellow Birch}

Betula lutea

Resembles the preceding; bark is silvery gray or light orange; leaves hairy along the veins beneath; one of the most valuable forest trees in the northern states. A blaze of gold in autunn.

\section{Canoe, or Paper Birch}

Betula papyrifera

Ornamental tree, with very white trunk and loose, graceful head when older; leaves large and handsome.

\section{Western Catalpa}

Catalpa speciosa

Tall and hardy; well adapted to forest and ornamental planting; white flowers.

Similar to those of the Chinese eatalpa.

\section{American Beech}

Fagus grandifolia

A magnificent tree; large, spreading growth; symmetrical; smooth gray bark attraetive in Winter.

Purple-leaved Beech

Fagus syliatiea purpurea A purple-leaved variety of the preeeding.

European Beech

Fagus sylratica Choice and beautiful tree; retains foliage very late; excellent for sereen.

\section{White Ash}

Fraxinus alba

Well-known native variety, with straight, clean trunk; soft, mellow green foliage when young.
F R A M I N G H A M
N U R S E R I E S
F R A M I N G H A M, 
The finest of all purple-leaved trees; compact, symmetrical growth; crimson foliage early in the spring, elanging to dark purple in the summer.

*Tulip Tree, or Whilewood

Liriodendron tulipifera A large tree; smooth bark; glossy, light green, liddleshaped leaves; branches spreading. The flowers are 'Tulip-like, of a greenish-yellow color, blotehed with orange.

\section{Silver Poplar}

Populus alba

From Europe. Rapul growth and spreading habit; leaves glossy alove and white as snow beneath. Flourishes in any soil.

Gray Poplar

Populus alba eanescens

A broad-leaved variety; the young shonts are very graty and woolly. Iseful for foliage effects in large plantings.

\section{Carolina Poplar}

ropulus dcltoides

I popular tree where slatde is wanted quiekly; pyramidal in form; bark gray-green; foliage heat shaped, and of a bright green color; very valuable for shade.

\section{Lombardy Poplar}

Populus fastigiata

A well-known, upright and extremely rapid grower; leaves bright, pale green, lighter beneath; indispensable in landseape gardening; as it tends to relicve the ordinary monotonous outlines of most other trees; Jargely used for sereen purposes.

\section{Simon's Poplar}

Populus simonii

A strong tree, with large, glossy leaves like Balsam Poplar. I distinct, quick growing variety; valuable for wiudbreaks and seashore planting.

\section{White Oak}

Quercus alba

One of the noblest trees of the Northern states. Beautiful park tree; foliage assumes a violet-purple color in the fall.

\section{*Scarlet Oak}

Quercus coceinea

Especially valuable for its brilliant scarlet fall eolor. Grows well in dry situations. Leaves are large and feathery.
P'cculiarly laandsome tree when young; used for arenues. Leates deep green, furning to red in the fall, fincly divided, Drooping branches. (irows rapidly and prefers some'wlat moist soil. Fibrous rooted and trans plants well. Superbl lawn tree.

\section{Red Oak}

Quercus rubra

A broad tree of rapid growth; large, rich foliage, which turns to a bronzy red in the fall. Beservedly populatr.

\section{European Mountain Ash}

Sorbus aucupatia

Fine tree, bearing alusters of scarlet burries from July to winter, making it very attractive.

\section{Oak-leaved Mountain Ash}

Sorbus quercifolia Pyramidal habit; Oak-like leaves, green ahove and woolly underneath.

\section{*Crimean Linden}

Tilia dasystyla

Leaves tough and leathery; dark, glossy green above and pale beneath, with tufts of brown hairs on the axils of the principal veins; bright yellow bark in winter.

\section{*Furopean Linden}

Tilia europaen

Very fine pyramidal tree of large size, having large leaves and fragrant flowers. Very desirable.

*Small-leaved European Linden Tilia europaca parifolia Of slower growth, leaves small, thin, cordate, green ahove, silvery beneath, with tufts of rusty bairs in the axils of the veins. Blossom very sweet scented.

\section{*American EIm}

I'mus amerieana

Lofty and spreading, with drooping branches. Most comnon and beautiful of the Elms.

\section{*English Elm}

C'mus compestris

Round-topped and sometimes open-headed tree. Often used for avenues. Foliage dark green, remaining several weeks longer than that of the Imerican, and is more delieately cut.

\section{PRICES}

Owing to seasonal fluctuations in the prices of nursery stock we have discontinued the practice of inserting prices in this general descriptive eatalog. The information in this book holds good over a long period and for this reason we recommend its preservation. Scasonal price lists will be mailed you twice a year-March Ist and September 1st. If however you do not receive them please notify us. 


\section{Piazza and Pergola Plantings}

In the creation of attractive piazza "cozy-comers," back or front yard arbor-ways, and the simpler forms of garden pergolas, the plants listed under this classification comprise varieties suitable for the most effective, practical results. In planting, a trellis of some kind is always necessary for the plants to train upon. Piazza trellises can be very easily and inexpensively constructed of wire or painted laths - the simpler the better, as it is desirable

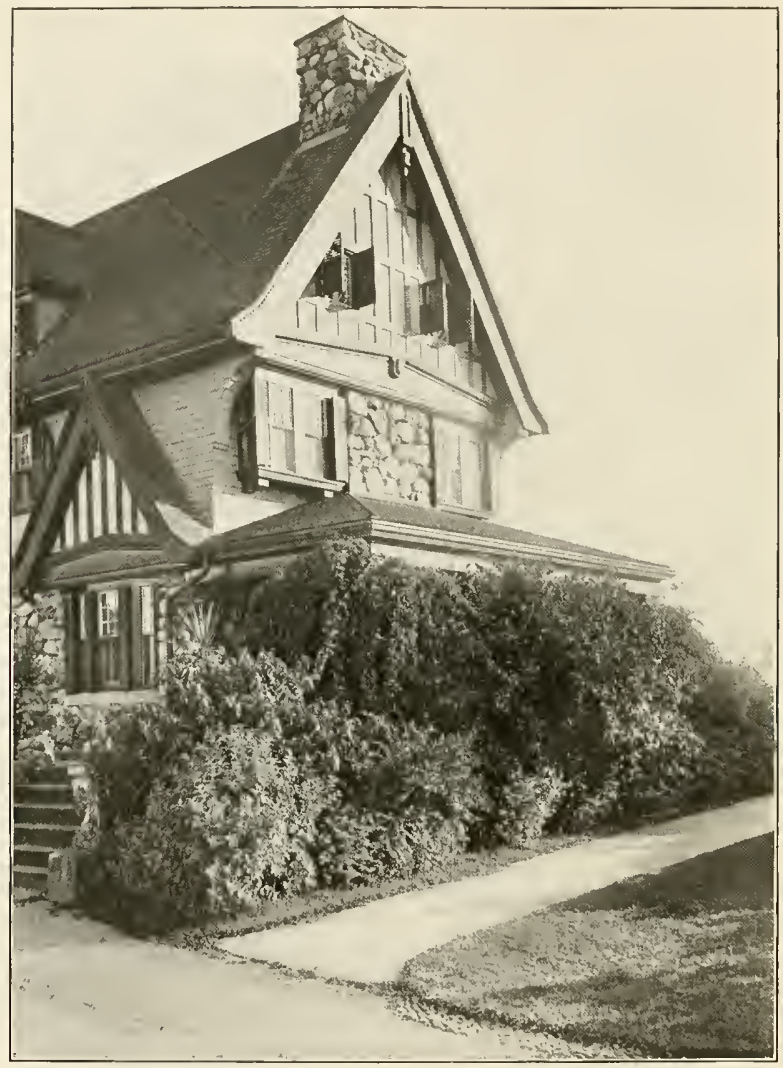

A Piazza "cozy corner"-giving seclusion, beauty, comfort and protection against summer dust.

to keep the trellis-work as unobstrusive as possible. In planning the construction of arbors, it is of course largely a matter for personal taste and judgment in conjunction with the exigencios of existing conditions such as available space, location, etc. alway bearing in mind, however, that until the plants are fairly well along in growtl, the base trellis-work must be sufficiently fine to permit speedy climbing.

F R A M I N G H A M N U R S E R I E S - F R A M I N G HA M, MA S S. 


\section{Vines and Other Climbing Plants}

Actinidia

A strong growing dapunese vilue with rithe Flowers white with purple eenter. Fruit is yellow edible, of sweet flavor.

Trumpet Vine Bignonia radicans A hardy, high climbing plant bearing large scarlet-orange trumpet shaped flowers in Angust. Foliage handsome dark green.

Japanese Clematis

('lematis paniculata One of the best vines. Luxuriant grower. Blooms profusely in summer; flowers are white, medium size, fragrant. Perfectly hardy. Grows well on a trellis.

Ilybrid Large-flowering Clenatis, all varieties.

Clematis Duchess of Edinburgh, Flowers double white, sweet-scenterl.

Clematis IIenryi,

Free blooming. Flowers large, creamy white.
Clematis Jacknanni, lilowers velvety purple.

Clematis Madam Baron Veillard, Flowers crimson.

Clematis Madam Edoward Andre, Flowers unique lint of soft pink.

Chinese IIoneysuckle

Lonicera brachypoda Foliage dark green and remains until very late. Flowers yellow and crimson colored, fragrant.

llall's lloneysuckle Loniccra brachypoda halliana Vigorous grower. Fragrant, yellow and white flowers from midsummer until frost.

Purple Wistaria

W'istaria chinensis Harly, fast-growing. Feliage compound, pale green. Long clusters of purplish pea-shaped flowers in May.

White Wistaria Nistaria chinensis alba A white-flowered variety of the preceding

\section{Climbing Roses}

American Pillar. I fine old variety. Flowers single, large, pink. Free blowning.

Crimson Rambler. The foliage is rich, dark green; the growth rapid and diverse, but its great beauty is when the plant is covered with a profusion of the brightest erimson, partly double flowers which remain on a long time.

Doctor Van Fleet. Flesh pink, viry fine. One of the hest of the new climbing roses.

Dorothy Perkins. This is a splendid new shell-pink climbing rose. It has the same strong labit of growth as the Crimson Rambler, and the flowers are borne in elusters of thirty or forty, sometimes fifty or sixty. The flowers are large for a Rose of this class, very double, and sweetly scentecl.

Dorothy Perkins Red (Excelsa). Very double crimsonmaroon flowers in large trusses. Of same habit as the above and holds its foliage better than the Crimson liambler.

Hliawatha. Glowing ruby-erimson, single flowers, with petals shading to pure white at the base. This delightful new Rambler has evoked mueh favorable comment.

Pink Rambler (Euphrosyne). Possesses the same valuable features found in the White Rambler, from which it differs only in color of flower, which is a brilliant light carmine.
Lady Gay. The flowery - in large, loose clusters - are of a delieate eberry-pink color, fading to soft tinted-white. The effect of a plant in full bloom, with the combination of soft white flowers, cherry-pink buds, and deep green foliage, is indeed charming. It is perfectly hardy.

Queen of Prairie. Bright rose-color; large, compact and globular; a very profuse bloomer. One of the best. Foliage large and quite deeply serrated.

Silver Moon. Silvery pink, yellow stamens. One of the better new roses

Tausendschon. A recent introduction which comes to us very highly recommended, making growtlis in a season of over ten feet, which are almost devoid of thortus. It bears its flowers in immense clusters; in eolor a soft pink when first opening, ehanging to a carminerose on the reverse as they fully expaud.

White Rambler (Thalia). Flowers are in the size of a silver quarter, perfeetly filled, very fragrant; color pure white, sometimes tinged with blush. Blooms in elusters.

Yellow Rambler (Aglaia). Flowers medium size, eupsliaped, nearly full, sweet-scented; blooms in large clnsters; color very light yellow: Of the class and habit of the famous Crimson Rambler.

\section{Individual Specimens}

The day has now gone by when single specimen trees scattered here and there over the lawn were considered int good taste.

On large estates groups of several specimens may be planted in carefully selected spots. On small estates lowever, especially on suburban lots, the lack of space precludes such grouping. In such ease, interesting specimens should be made into border or screen plantings, giving each tree or shrub more space than ordinarily used, so that it may develop its individual characteristies unhampered.

The most interesting specinens are to be found among evergreens. Almost all the evergreens listed on pages 50 to 57 are interesting for their individual characteristics.
“ T H E
S T A N D A R D
$\mathrm{O} \mathrm{F}$
Q U A L I T Y
F O R
A M E R I C A " 
Among deeiduots trees suitable for speeimen plantings are the varieties listed moler "Shade Plantings" and the following sorts which atre valuable for their flower or leaf effect.

Flowering Cherries

Cerasus varietics

The following cherries are recent introdnctions from Japan and have not yet acquired a common name.

Cerasus japonica flora plena alba

Foliage heavy and vigorons, handsome. Flowers are white and double in May.

Cerasus japonica flora plena rosea Similar to the preceding. Flowers are pink and double in May.

Cerasus japonica hisakura

An improvement on the preceding.

White-flowering Dogwood

Cornus florida

Native. Ilabit irregular; top open and spreading. Usnally attains about $20 \mathrm{ft}$., sometimes $40 \mathrm{ft}$. Large showy white flowers in May before the leaves appear. fn autumn the grayish green foliage turns to dark red, which with the brilliant red berries make it one of the most heautiful trees of the fall season.

Red-flowering Dogwood Cornus flarida rubra Similar to the preceding. Flowers decp rose. 3 to 4 it.

\section{Carriere's Hawthorn}

Crataegus carrieri Foliage glossy dark green. Flowers in May. Fruit large, dark red, showy and hangs to the tree until late in the Winter.

Scarlet-fruited Thorn

Crataegus coccinea

Native, Large foliage. White blossoms in May followed by scarlet fruit.

Washington Thorn

Crataegus cordata White Flowers in May and June. Beautiful fall coloring of foliage. 13right red fruit.

Cockspur Thorn

Crataegus crus-galli Foliage glossy green turning to brilliant orange and scarlet. White flowers in May and June. Its numerous long strong thorns make this plant admirable for large hedges where a positive barrier is desired.

Common Hawthorn

Crataegus oxyacantha

The celebrated English hedge plant. Flowers pure white, sweet scented, in May, followed by scarlet fruit.

Double White Hawthorn

Crataegus oxyacantha flore plena alba A variety of the preceding with small donble, white flowers.

Paul's Scarlet Thorn

Crataegus oxyacantha flore plcna coccinea Similar to the preceding. Flowers large, scarlet crimson, very double.

Weeping Beech

Fagus sylratica pendula A picturesque tree with long drooping branches. The longer limbs spread horizontally. Rich luxnriant foliage hangs down in masses.

\section{INDIVIDUAL DEGIDUOUS SHRUBS}

Any of the shrubs listed for foundation planting and for sereen and border planting are suitable for this purpose. Merely give more room than usual.
N U R S E R I E S -
F R A M I N G H A M,
M A S S.

Weeping Purple Beech Fagus sylvatica purpurea pendula Similar to the preceding. Leaves purple.

Maidenhair Tree

Ginkgo bilaba Native of Japan. Mediun size. Clean, straight trunk. Foliage resembles the Maidenhair Fern.

Varnish Tree Koelreuteria paniculata From China. Large leaves. In July produces a mass of showy orange-yellow flowers, followed by curious seed vessels.

Golden Chain Laburnum vulgare A small tree deriving its name from the long chains of golden hlossoms in June.

European Larch

Larix europaea Pyramidal tree. Terminal branchlets drooping. Foliage light green - similar in size and shape to Sprnce foliage. Bears cones.

Alexander's Magnolia Magnclia alexundrina Large, light pink, waxy flowers early in May. Large dark leaves.

Soulange's Magnolia

Magnolia soulangcana One of the hardiest and most popular Magnolias. Flowers in April, white inside, pink outside. Foliage dense and glossy.

Showy-flowered Magnolia

Magnolit speciosa Resembles the preceding. Flowers are smaller, later of appearance and deeper in color.

Hall's Magnolia

Magnolia stellata Dwarf habit. Spreading branches. Blooms earlier than other Magnolias, producing donble pure white fragrant flowers, petals long and narrow.

Flowering Crab

Malus flaribunda Flowers rose or rosy red, appearing with the leaves, in great abundance. Very showy. Fruit very small, ornamental in autumn.

Crimson Crab Malus floribunda atrosanguinea Profusion of crimson flowers. resembling small roses.

Scheidecker's Crab Malus flaribunda schcideckeri Double, bright rose flowers. Exquisite.

Parkman's Crab Malus parkmani Irregular halit. Carmine colored, semi-double blossons on pendulous stems.

Japanese Tree Lilac

Syringa japonica One of the remarkable tree lilacs from Japan. Flowers creamy white in July.
Bechtel's Double-flowering Crab
F R A M I N G H A M 


\section{Plants to Attract Birds}

In planting trees, shruls and vines about a place, it is woll to bear in mind those varieties which, on accomt of their secels and fruit, attract the hirds; and it is anlvisalshe to inchude some of these sorts in your planting. Birds play an inproptant part in the economy of nature and are an attractive leature of home surromidings.

Persons interested in Game P'rescrves, shonld give attention to the virieties listed below as attractive to game birds. 'The subject of (iame Preserves is too large to present in detail here. We shall he very glat to give special detaled informat ion howere to persoms interesterl.

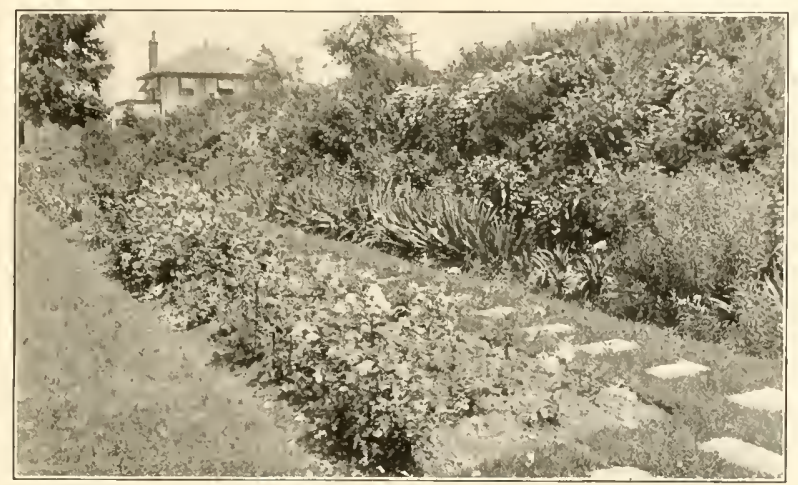

A screen of mixed deciduous shrubs, specially selected to attract birds, surrounding a rose and perennial garden. Oldfashioned charm in an entirely new-fashioned setting.

Iome gardener's who have had crops damaged hy such birds as crows and sparrows can gain protection by planting nearby the varicties of shrubs upon which those particular bird-pests feed, and thus keep them away from the garden itself.

Below we give a list of those trees, shrubs and vines which are fruit-bearing and fumish food for Birds; also a list of the birds which feed on the rarious kinds. 'The deseriptions of the plants will be found in this catalog, on pages referred to below.

Service Berry

Amelanchier canadensis

Altracts birds Nos. 1, 2, 4, 6, 8, 10, 13, 17, 20, 25.

Virginia Creeper

See page 46. Atlracts birds Nos. 2, 6, 9, 19, 14, 16, 17 , ]8, 25.

Japanese Barberry

Common Barberry

Purple-leaved Barberry

See pages 28 and 39 . Altract birds Nos, 4, 6, 9, 12, 14, $16,17,18,25$.

Bittersweet

Japanese Bittersweet

Cilustrus scundens See page 46. Attract birds Nos. 2, 9, 14, 16, 17, 25 .

Burning Bush

Spindle Tree

Pink-fruited Spindle Tree

See pages 26 and $2 \pi$. Illract birds $\mathrm{Yos}, 2,6,10,1$

\begin{abstract}
Blue Dogwood
Bailey's Dogwood

Gray Dogwood

Cornelian Cherry

European Red Osier

Silky Dogwood

Siberian Dogwood

American Red Osier

Yellow-s temed Osier See pages 26,27 and 24 . Attract birds Nos. $1,2,3,4,5$, $6,8,9,10,12,14,16,17,18,19,21,23,25$.
\end{abstract}

Common Juniper

Red Cedar

Juniperus communis Juniperus virginiana See page 51 . Altrart, birds Nos. 2, 4,6 , $7,8,12,15$, $16,17,18,22,21,25$.
European Mountain Ash
Oak-leaved Mountain Ash
Sorbus aucuparia Sorbus quercifolia See page 39. Altract birds Nis. 2, $1,7,8,9,14,17$, 18,25 .

“T H E S T A N D A R D O F Q U A L I T Y F O R A II E R I C A , 

$\begin{aligned} & \text { Bayberry } \\ & \text { See page } 45 . \text { It tracts birds Nos. } 1,5,6,9,12,14,16,\end{aligned}$ $17,18,19,24,25$

Buckthorn

Carolina Buckthorn

Rhamnus catharica Rhamnus caraliniana See page 27. Attract birds Nos. 3,4, 8, 10, 11, 12, 17, 21 .

Smooth Sumac

Staghorn Sumac

Rhus ylabra Rhus typhina See pages 26 and 27. Attracl birds Nos. 1, 2, 3, 4, 5, 6, $8,9,10,12,14,16,17,18,19,21,23,24,25$.

Elderberry

Sambucus canadensis

Golden Elderberry

Sambucus nigra aurea

See page 28. Attract birds Nos. $1, z, 3,4,6,8,9,10$, $11,12,13,14,15,16,17,18,21,23,25$.

Blueberry

I'accinium coryumbosum See page 28. Attracts birds Nos. 3, 4, 6, 9, 10, 12, 14, $17,18,25$.
Meadow Rose

Swamp Rose

Wild Rose

Japanese Climbing Rose

Shining-leaved Rrose

Sweet Briar Rose

Red-leaved Rose

Japanese Rose

White Japanese Rose

Prairie Rose

Memorial Rose

See Page 45, Attract almost all of the birds listed below,

Arrow-wood

Wayfaring 'Tree

Sheep-Berry

High-bush Cranberry $16,17,18,21,24,25$.
Rasa blanila

Rosa carolina

Rosa lucida

Rasa multiflora

Rasa nitida

Rosa rubiginosa

Rosa rubrifolia

Rasa rugosa

Rosa rugosa alba

Rosa setigera

Rosa wichuriana

I iburnum dentatum

V'iburnum lantana

Viburnum lentago

I'iburnum opulus

Attract birds Nos. 2, 4, 6, 9, 14,

\section{KEY TO THE BIRDS}

The following is a list of the birds which feed upon the fruits of the shrubs listed above. The numbers correspond with those in the list of plants.

$\begin{array}{lllll}1 \text { Blackbird } & 6 \text { Grow } & 11 \text { Junco } & 16 \text { Quail } & 21 \text { Thrasher } \\ 2 \text { Bluebird } & 7 \text { Finch } & 12 \text { Kingbird } & 17 \text { Robin } & 22 \text { Thrush } \\ 3 \text { Catbird } & 8 \text { Grosbeak } & 13 \text { Oriole } & 18 \text { Sparrow } & 23 \text { Vireo } \\ 4 \text { Cedarbird } & 9 \text { Grouse } & 14 \text { Pheasant } & 19 \text { Swallow } & 24 \text { Warbler } \\ 5 \text { Chickadee } & 10 \text { Jay } & 15 \text { Phoebe } & 20 \text { Tanager } & 25 \text { Woodpecker }\end{array}$

\section{Natural Plantings}

Where the home gromnds are very extensive, it is often desirable to give some part of it up to a Natural Planting. This is done by planting those things which are native to the immediate regions. Varieties that are not native, but which have similar characteristics, may be used. These plantings should be made of irregular elumps made up of several plants of a kind - rarely more than two kinds in a group. The grouping of such a planting requires thorough study of the surroundings.

The following lists enumerate varieties suitable for such a purpose in New England. A dagger $(\dagger)$ indicates those varieties suitable for sea-shore planting.

\section{Shrubs}

\begin{tabular}{|c|c|}
\hline $\begin{array}{l}\text { Common Barberry } \\
\text { See page } 28 .\end{array}$ & $\begin{array}{l}\text { American Red Osier } \\
\text { Thrives in damp places. See page es. }\end{array}$ \\
\hline †Sweet Pepper Bush Clethra alnifalia & Witch Hazel \\
\hline $\begin{array}{l}\text { Rich green foliage. Spikes of creamy-white fragrant } \\
\text { flowers during the greater part of summer. 'Thrives in } \\
\text { met places. }\end{array}$ & $\begin{array}{l}\text { One of our best native sbrubs. Strong growing. Showy } \\
\text { yellow flowers appear after the ripening of the leaves } \\
\text { in November. }\end{array}$ \\
\hline †Sweet Fern $\quad$ Comptonia asplenifolia & \\
\hline $\begin{array}{l}\text { Fern-like, dark green aromatic foliage. Brownish flowers. } \\
\text { A very low growing plant which thrives on barren and } \\
\text { rocky soil. }\end{array}$ & $\begin{array}{l}\text { Yellow-stemmed Osier } \\
\text { Prefers damp soil. See page } 28 .\end{array}$ \\
\hline $\begin{array}{l}\text { †Gray Dogwood } \\
\text { Good for damp places. See page } 26 \text {. Cornus paniculata }\end{array}$ & $\begin{array}{l}\text { fWinterberry, or Black Alder } \\
\text { See page } 28 . \text { Prefers damp soil. }\end{array}$ \\
\hline
\end{tabular}


Shrubs (Continued)

†3asberry

Myrica ecrifera Iow, spreading. Thrives in sandy places, and near the seashore. Polinge dark green, nearly evergreen, aromatic. Plowers are ineonspicuous, followed by white or gravish waxy lorries.

$\dagger$ Fragrant Sumac

Rhus aromaticu Ster page $? 7$.

†Smooth Sumac

Rhus glabra See page 27 .

Staghorn Sumac Sie page 96 .

Rhus typhina

Wild Roses

Rosa species Several of the species listed bolow are native to Imeriea. Others, although native elsewhere, haw similar general characteristics

Meadow Rose

Rosa blanda The slender red branches are alnost thornless; foliage oval, pale green; flowers are large, bright rose-colored, single; blooms in Nay.

\section{Swamp Rose}

Rosa corolina The tall-growing Wild Rose, with single pink llowers during the summer months; its bright red fruit is very showy.

\section{†Wild Rose}

Rosa lucida A dwarf native variety, with stems thickly covered with prickles; foliage dark green, shining above; flowers single, rosy pink about two inches across; does well on poor soil.

Japanese Climbing Rose

Rosa multiflora A Japanese variety of rapid growth, forming a round, drooping shrub when standing alone; its proper plaee, however, is mixed with other shrubbery; its single, pure white flowers are produced in great quantities, followed by an equal number of small searlet frnit in winter.

†Shining-leaved Rose

liosa nitida

The branches are completely covered with straight prickles and bristles; foliage bright green, glossy; flowers are highly colored bright pink.
Red-leaved Rose

Rosa rubrifolia

Upright grower, with slender purplish brancless, covered with glateous bloom; foliage bluish grecu, tinged with red, and is vary effewtive als it red follage shrub; flowers scarlet in tune.

tSweet Briar Rose

Rosa rubiqinosa 'The wetl-known sweet Briar with highly scented foliage, small, pink, fragrant llowers, and quantitics of bright fruit. Jlooms in .I une.

Prairie Rose Rose setigera large single flowers of decp rose-eolor. It is a climber. and when trained over a veranda makes a brantiful display.

Menorial Rose

Rosa wirhmatana Ised extensively for covering embankments and stoncwork; it ereeps rapilly over the surface, forming a mat of dark foliage; flowers are pure white, borne in clustrers and fragrant.

†Elderberry See page 28 .

Šambucus canodersis

Golden Elderberry

See page gs.

Willow-leaved Spirae:

Sipiraca salicifolia Small shrub bearing light pink or white towers in long dense panicles in June and July. Prefers wet places.

Hardhack

Spiraca tomentosa I small native shrub with few stems surmounted by large deep pink or purple spikes of flowers in Juty and August. frows naturally in sandy upland soil.

Withe-Rod

Jiburnum cassinoides Fairly large shrub. Foliage smooth, turns to brilliant colors in fall. White flowers in flat elusters 3 to 5 inches broad in June and July. Round fruit, pink at first, turning to black.

Arrow-wood

Jiburnum dentatum Prefers moist soil. Sce page $\mathbf{9 6}$.

\section{Evergreens}

\section{†Balsam Fir}

See page 50 .

tCommon Juniper See page 51 .

tGolden Common Juniper See page 51.

† Red, or Virginia Cedar See page 51 .

tGolden Virginia Cedar See page 51 .

+Blue Virginia Cedar See page 51 .

White Spruce see page 51 .
Picea alba

Ibies bulsumea

Juniperus communis

I unipcrus communis aurea

Juniperus rirginiana

Juniperus rirginiana aurea

Juniperus virginiana glauea
"T I E
O J
† Jack Pine

Sce page 5.?

tWhite Pine See page 53.

American Yew See page it.

American Arborvitae see page 5.5.

American llemtock see page 5.5.

Globe-shaped Ilemlock see page 5.5 .
Pinus divaricata

Pinus strobus

Taxus contedensis

Thuya occidentalis

Tsuga cumadensis

Tsuga canadensis globosa
L. I T Y F O R

I M E R I C A," 


\section{Vines}

Valuable for trailing over rocks and stone walls.

Virginia Creeper

1 mpelopsis quinquefolia

A vigorous high climbing viue of rapist growth. Foliage rich erimson in antumn.

Trumpet Vine

Bigonia radicans

I hardy, high climbing plant hearing large searletorange, trumpet shaped flowers in lugust. Foliage, handsome dark green.

Rosbury Waxwork (Bittersweet) ('elustrus scandens I native climber with glossy leaves. Orange fruit in dusters hangs on stems all winter.
Japanese Bittersweet

Celastrus paniculatus 1 Japanese variety similar to the preceding; fruit crimson

\section{Wild Clematis}

Clematis virginiano

Native. Rapid growing. White flowers in August followed by feathery white seeds which are very decorative.

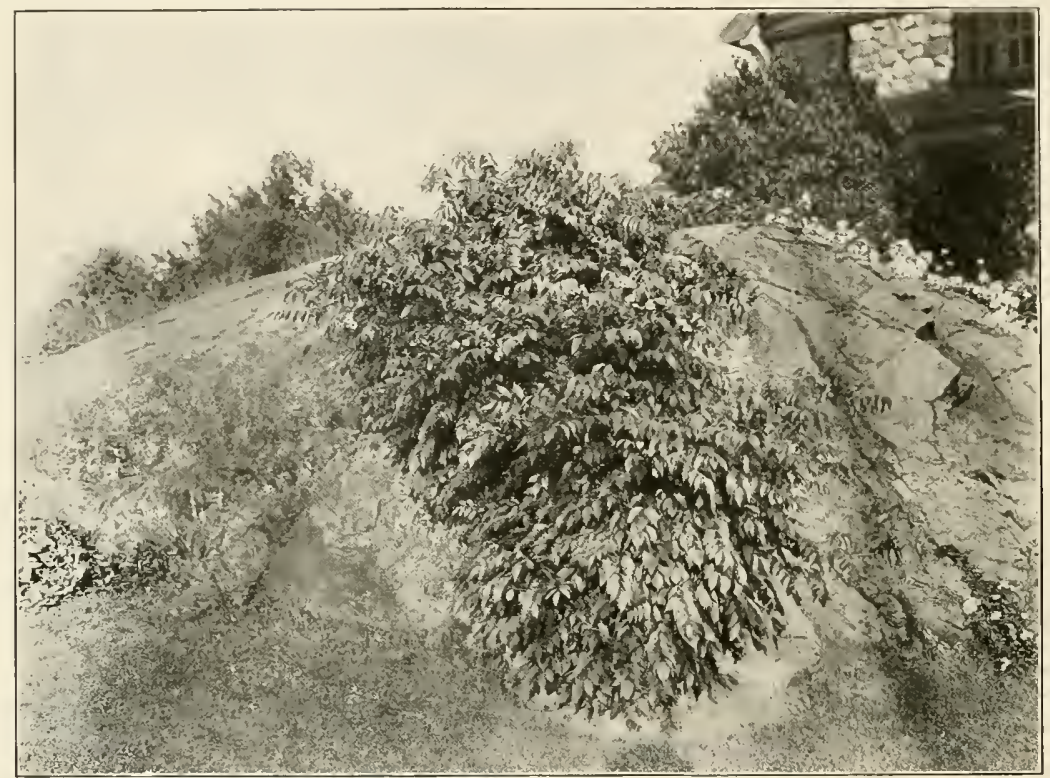

A bare rocky place made attractive by the planting of a Trumpet line

\section{Trees}

\begin{tabular}{|c|c|c|}
\hline $\begin{array}{l}\text { Red, or Swamp Maple } \\
\text { See page } 37 \text {. }\end{array}$ & Aeer rubrum & $\begin{array}{l}\text { †Silver Poplar } \\
\text { See page } 39\end{array}$ \\
\hline $\begin{array}{l}\text { Sugar Maple } \\
\text { See page } 37 .\end{array}$ & Acer saccharum & $\begin{array}{l}\text { White Oak } \\
\text { See page } 39 .\end{array}$ \\
\hline $\begin{array}{l}\text { Black Birch } \\
\text { Spe page } 38 .\end{array}$ & Betula lewta & $\begin{array}{l}\text { Scarlet Oak } \\
\text { See page } 39 .\end{array}$ \\
\hline $\begin{array}{l}\text { Yellow Birch } \\
\text { See page } 35 .\end{array}$ & Betula lutca & Pin Oak \\
\hline $\begin{array}{l}\text { Canoe, or Paper Birch } \\
\text { See page } 38 \text {. }\end{array}$ & Betulu papyrifera & $\begin{array}{l}\text { Red Oak } \\
\text { See page } 39\end{array}$ \\
\hline $\begin{array}{c}\text { American Beech } \\
\text { See page } 38 .\end{array}$ & Fagus grandifolia & $\begin{array}{r}\text { American Elm } \\
\text { See page } 39\end{array}$ \\
\hline
\end{tabular}

Populus alba

Quercus alba

Quereus coccinea

Quercus palustris

Quercus rubra

T'mus americana

F R A M I N G H A M N U R S E R I E S - F R A M I N G H A M, MA S S. 


\section{Plants for Odd Purposes}

\section{SHRUBS}

Sh buld bx planted is fert a jatrt.

Coral Berry

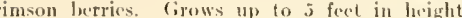

Fine for shindy platers. It s thickly matterl roots prevent soil washing.

Drooping Golden Bell

Forsythia suspensa Branches drooping. fitems covered with yellow bellshaperl flowers in Iprit. leawes rich erern, turning porplish in autumn. Ittains a height of cinht feet. tower branches mat down, thus preventing soil wasling.

\section{VINES}

Should be planted overy is or $2+$ inches.

Chinese lloneysuckle Lonicera brachypota Foliage dark grem, nearly evergren, flowers yellow atul eremom-olored, fragrant.

Ilall's floneysuckle

T.onicere breshyporda hallianu Vigorous grower. Fragrant vellew and white flowers from mill-kummor mulil frost.

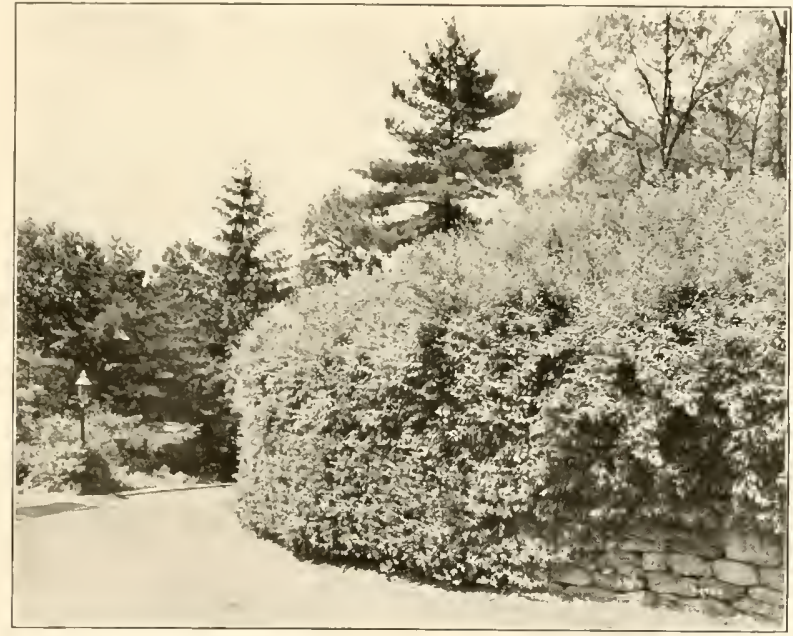

A retaining Wall planted on outside with Large-leaved Evergreen Bittersweet, with deciduous shrubbery forsythia Fortunat on inside. Note the luxuriant mass effect where otherwise the vista would be harsh and unattractive.

\section{For Covering Masonry or Brick WaIls}

Evergreen Bittersweet

Euanymus radicans:

Ifalf shrub, half vine. Planted in the spen it grows up. right, generally conical in shape. Planted against a wall, it clings and climbs making a close flat eovering. Leaves $3 / 4$ inch long. Evergreen.

Variegated Evergreen Bittersweet

Exanymus radicans variegata Similar to Evergreen Bittersweet, but leaves are variegated with yellow, white and pinkish tints

\section{Ground Covers for Shady Places}

Oftentimes a portion of one's lawn is so shaded that grass does very poorly. In such a place, a low growing ground eover plant is desirable. For this purpose, the two following species are best.

Trailing Myrtle

linea minar

I handsome traiting plant with exergreen foliage. Showy bright blue flowers borne freely in early spring and at intervals throughout summer and fall.

"T II E

$S \mathbf{T} A \mathrm{~N}$

D $\Lambda$ R D

O F

Q U A L 1 I T $\mathbf{Y}$
P'achysandra terminalis Japanese Spurge low-growing evergreen plant. White flowers on short
spikes. Its bright green foliage makes a beautiful carpet should be planted 6 to 12 inches apart. The eloser they are planted, the quicker the result.

finilar to the preceding. Leaves largor. Nore rapisl grower. Hushier, does not lic fat to a wall, but makes a bushy covering. 
We have in no way attempted to eover this subject in its entircty, or as relative to the complete planning and planting of formal or informal flower-gardens. Rather, realizing that the occasional decorative rose-bed is generally a much more practical source of beautification and gratification on the average residential grounds than the garden of larger dimensions might be, we have presented suggestions most applicable to this specific use

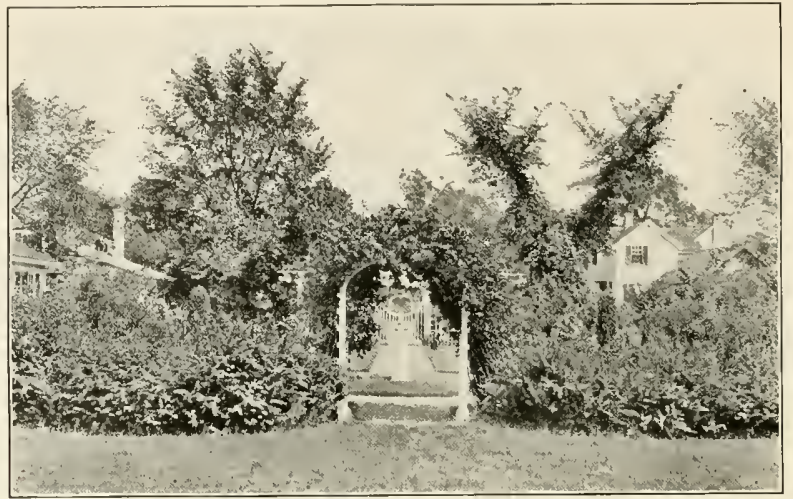

The borders of mixed deciduous shrubs at the entrance to this formal rose garden lend a very desirable touch of privacy and seclusion.

of decoration. In plaming sueh beds, it is important that species such as are listed here should be planted in beds separate from any other sorts of shrubs; that is, while for artistic effect it is sometimes desirable to mix the Rose varieties or colors in single beds, for best results they never should be mixed with other plants or shrubbery. Wild sorts, suitable for this purpose, will be found nnder "Natural Plantings".

\section{Hardy June Roses}

In this list we have besl varieties of the gool old sorts, that do best in our New England climate and are always in demand on account of their hardiness and beantiful bloom, although their period of blooming is short.

American Beauty. Large, reil, beauliful of form, and very double. The fragrance is delightful resembling La France.

Fisher Holmes. H.P. May be briefly described as an improved General Jacqueminot; the flowers are fuller and more freely produced. A very valuable sort.

Frau Karl Druschki, or Snow Queen. H.P. A pure paper-white, free-flowering, large size; a remarkably handsome plant, with bright, heavy foliage and strong, upright growth; the bloom is perfect in form, on nice long stems, and of the purest possible white. There is nothing in the line of perfectly hardy roses that can compare with this one in form, color and general finish.

General Jacqueminot. II. Ch. Brilliant crimson; not full, but large and extremely effeclive; fragrant and of excellent hardy habit; forces well. One of the best known and most popular red roses grown.
IIarrison's Yellow. A. Golden yellow, medium-sized semi-double; generally has nine leaflets; a freer bloomer than Persian Yellow, but not so harily.

Louis Van Houtte. Red, shaded crimson; large, full, fine form; fragrant.

Madam Gabriel Luizet. H.P. Silvery pink; fragrant; fine foliage; vigorous; exquisite in bud. This rose has no superior.

Margaret Dickson. If.P. A magnificent rose ; white, with pale flesh center; petals very large, shell shaped and of great substance; fragrant; foliage large, dark green. Very vigorous.

Mrs. John Laing. H.P. Soft pink; large and of fine form, produced on strong stens; exceedingly fragrant; one of the most valuable varieties for forcing; flowers continuously in open ground.

M. P. Wilder. II.P. Of vigorous growth, wilh healthy foliage; flowers large, semi-globular, full, well formed; cherry-carmine, much like a light-colored Marie Baumann; very fragrant. It resembles the Alfred Colomb in wood, form and foliage, but excels that variely in vigor, hardiness and freedom of bloom. Continues to bloom long after other hybrid perpetuals are out of bloon.
F R A M I N G H A M
N U R S E R I E S 


\section{Hardy June Roses, Continued}

Paul Neyron. 11.l'. Derep rose; very large, very full; somewhat fragrant; fres-litooming; the wood is nearly smooth, the foliage tough and enduring; somewhat tender; the growth is upright. largest variety known; very desirable for the garden.

Persian Yellow. A. lbright yellow; small, nearly full, well formed; small folliage, faintly seented like the swerthrier; seven leaflets; the worl is chooblate-brown in color, armed with numeroms brown thorns; it is the finest of all hardy yellow roses. It must not be closely prined.
P'rince Camille de Rohan. If. p'. Very deep velvety erimson; large, moulcrately full; habit somewhat spreat ing : sloy ju atutumu. I gooul rose of splemelid color lut a moderate grower.

Ulrich Brunner. 11.1'. Brillian eherry-red, very effective in color; 15owers of fine form and linish, earried well] upon the plant; petals of great substanes; vigorous, hatrdy, resists mildew. One of the best for foreing and open-air enlture.

\section{Ever-blooming Bedding Roses}

Of late great attention has been given to the roses hy all the leading rosarians in boll Europe and Imerica. Is a result a elass of ever-blooming roses has been reveloped thit are valuable.

Heretofore we have had roses that gave an alumdance of blossoms in .June and a few at intervals thromglont the seasom. Now it is possible to have atu at bumbatuce in ,July, lugus ant september as well as in Jume.

There are humbeds of these varieties, sueh as Kaiserin Augusta Victoria and (iruss an 'Teplitz, already quile generally and favorably known. Some of these sorts like all hybricls have a delicious perfume while some are odorless.

We recommend our patrons - and we cannot do it too strongly to try these few sorts that we now offer, then they will he prepared to jurlge intelligently of their worth amb to oreler more largely the following stason.

\section{VARIETIES}

Baby Dorothy (Pink Baby Rambler). J'. ('luar brilliant pink and very freely protuced. Vigorons.

Baby Rambler. A eross between Crimsen Rambler and Glory of Polyanthus. It is as free blooming as the latter and of the same color as the former. It is very vigorons and quite hardy; foliage is of a beautiful, deep, glossy green. It flowers in large clusters.

Baby Rambler White. like the above, differing only in that it las white flowers.

Columbia. Most pleasing brilliant rose piuk, perfect form, fragrant, vigorous and free blonming. New.

General Mactrour, Bright erimson; large, full, free, highly perfumed; very fine.

Gruss an Teplitz. Hlower is quite double, with the deepest possible shade of crimson searlet, approaching erimson maroon in the older flowers. Its halit of growth makes it one of the finest Bush Roses for ontdior planting, being very free and vigorous; niwely colored, with is strong tera fragrance.

Iladley. Decp velvety crimson, does not fiule. Enormons flowers perfectly formerd and sweet merented. Vew.

Hugh Dickson. Brilliant crimson. The plants are strong and thrifty, with healthy dark green foliage. Blwoms continually. The flowers are of gool size and fine form and retain their intensity of color until pectisls fall. Very fragrant.
Jessie. I'. Flowers in lunge chusters of bright deerry(rimson which dees not fade. The of the best dwirf bedkling roses.

Julied. Outside gold, inside rich rostrint. Excellent.

Kaiserin Augusta Victoria. Delicate areamy white deliciously fragrant. As a cut flower it las few equals, blooming continnously from early spring till fall.

Killarney, In exquisite rose. The bush is strong and upright, with beautiful, deep, bronzy-green foliage. The color of the flower is deep, brilliant shell pink, of the most exquisite shades; large buds, long and pointed; bloums profusely throughout the season.

Killarney, White. Same as Killarney exeot color is pure white.

La France. Flowers large, silvery peach; buds long; very free thowering; fragrant.

Los Angeles. Lumbuts flame pink, toned with eral and shinded with gold at lasise. long pointed buds opon into perlectly formos flowers. Very frogrant. Nies.

Madame Caroline Testout. II.T llowers latge, very Ioul, le; silvery rose; free bluomer.

Mrs. Aaron Ward, ]1.T. Flowers coppery-orange in open bud, pinkish fawn when fully open,

Mrs, W. C. Miller. Solt prarly loluh, rony salmon ontside.

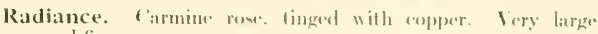
amil fine.

Sunburst. Brilliant yollew orange 


\section{Suitable for Foundation, Screen, Border, or Windbreak Plantings}

Whether or not heretofore listed under these separate classifications and their various ramifications.

FIR - Abies

Balsam Fir

Abies balsamea

Slender pyramidal form. Foliage dark green, silvery beneath. Thrives best in moist soil, but does well on fairly dry soil. Oltimate height 50 to $80 \mathrm{ft}$.

\section{Dwarf Hudson Bay Fir}

Abies balsamea hudsonica

Dwarf form of the preceding. Compact. As broad as tall. A very interesting plant.

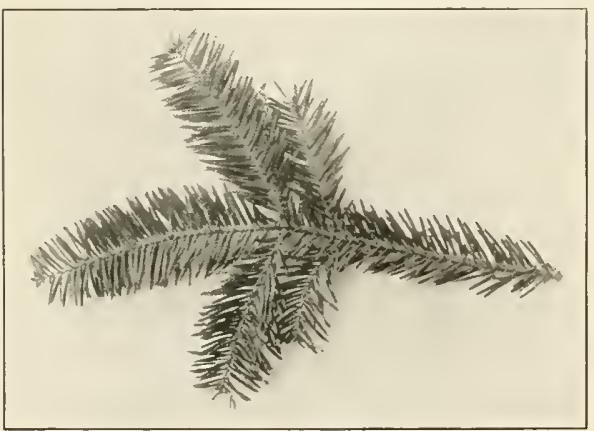

Fir Foliage
Frazer's Fir Abies frazeri Similar to Balsam Fir, but is suitable farther south than the Balsan. Foliage richer and darker. 17timate height about 50 feet.

\section{White Fir}

Abies conealor

Native to Rocky Mountains. Foliage long and broad; color variable from light yellowish green, to dark green and silvery blue. Best of all Firs. Vigorous and rapid grower. Withstands great heat and drouglit.

\section{Dwarf Frazer's Fir}

1 bies frazcri prastrata

A sport from the preceding. Broader than tall, tops as flat as a table. Foliage lighter than Frazer's Fir and a new distinctive dwarf plant which originated here. Obtainable only at Framingham Nurseries.

\section{Japanese Fir}

Abies brachyphylla

Broad symmetrical tree when mature. Attains about 75 feet. Foliage light green. Very handsome.

Veitch's Silver Fir

Abies vitchii

Makes a tall symmetrical tree attaining about 80 feet. Foliage dark green and glossy, silvery on under side. One of the most beautiful firs when young as well as when old.

Douglas Fir - Pseudatsuga taxifolia Attains 100 feet. Beautiful when small, majestic when large. Leaves dark bluish green.

\section{JUNIPER OR CEDAR - Juniperus}

Chinese Juniper

Juniperus ehinensis

Broad pyramid. Branches slender. Leaves pointed and spreading; medium green to grayish green in color. should be sheared each year in June for best cffect.

\section{Silver-tipped Chinese Juniper Juniperus chinensis argentea} similar to the preceding. Foliage dark grayish green, sometimes even bluish. Terminal leaves occasionally white. Should be kept sheared.

\section{Golden Chinese Juniper Juniperus ehinensis aurea}

Medium pyramid. Foliage like Chinese Juniper except that on outside and at top it takes a bright yellow color.

\section{Chinese Trailing Juniper}

Juniperus chinensis recurva squamata

Very attractive. Long trailing branches are covered with many branchlets of bluish green foliage. If given room will often in a few years make a nearly circular mass of foliage several feet across and not over 10 or 12 inches in height. Excellent for Rock Gardens.

\section{Pfitzer's Juniper}

$J$ uiperus ehinensis pfitzeriana

Irregular shape. Branches horizontally spreading; branchlets slightly drooping. frows as broad is tall. Foliage rich green, slightly grayish. Particularly beautiful.

\section{F R A M I N G H A M N U R S E R I E S - F R A M I N G H A M, M A S S.}




\section{JUNIPER OR (EEDAR Juniperus (fontimued)}

\section{†Common Juniper}

Juniperus rommunis

The common type often seen in pastures. Habit spreading, branethes slightly asernting, twice as broal as tall. Foliage varies from light green to bluish green, with at purplish cast in winter. Valuabte for Natural Plantings and liock Gardens. See page tij

Golden Common Juniper Juniperus communis aurea Golden form of precelling. New foliage bright yellow turning to hronze yellow in winter. Good for Natural Plantings and Rock Gardens.

Polish Juniper Juniperus communis cracoria Narrow pyramid or eolumu. Somewhat dense. Foliage light groen, somewhat gratyish.

\section{Irislı Juniper}

Juniperus communiv hibernicu

Very narrow column. Very dense. Folinge grayish. Fine for formal effects. Makes a good tall, narrow hedge. see page 34 .

\section{Common Trailing Juniper}

Juniperus communis procumbens. Similar in habit to Chinese Trailing Juniper. Foliuge purple-green. Good for Rock Gardens.

\section{Swedish Juniper}

Juniperus communis succico Nearly similar to the Lrish Juniper. Tips of branchlets slightly drooping.

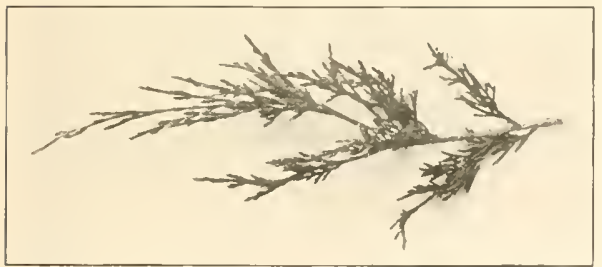

Juniper Foliaǵe

\section{Greek Juniper}

Juniperus ex elsa strich

Broad pyramid. C'ompat symuetrieal. Foliage somewhat bluish. Dwarf.

Japanese Jumiper

Juniperus japonica

Irregular spreading fan shape. at bottom. Foliage rich green.

Golden Japanese Juniper

Juniperus japonira auro Similar in form to the preceding, but spreads wider. Foliage bright yellow, turning to dull yellow in winter.

tSavin Juniper

Juniperus subina spreating fan-shaped habil, seldom erect. Foliage tark green, turning rich bronges gresen in winter.

Tamarisk-leaved Juniper

$J_{\text {kniperus subina tamariscifolia }}$

1)warf. Roughly globe-shaped, densely brancherl. Foliage handsome dark shade of green.

\section{$†$ Red or Virginia Cedar}

Jumiperus rirginiana

Often seen in native state ou sandhills along the Atlantie Coast. Ipright, varrow column. loliage varies from light green to dark green, grayish green and bluish green. Thrives in dry sandy soil. Not desirable north of Massachusetts.

†Golden Virginia Cedar Juniprus virginiana elegantissimu Sinilar to preceding. Foliage golden bronze.

$†$ Blue Virginia Cedar. Sinilar to Red Cedar. Foliage bluish gray.

\section{Globe-shaped Red Cedar}

Juniperus virginiana glabasa Form roughly globose. Foliage bright green. Japanese effect. Rare.

\section{SPRUCE - Pice}

\section{†White Spruce}

Piece albe

Native. Ipright, compact, long-lived. Ittains 70 feet. Foliage silvery green. Will stand severe pruning. Iseful as a hedge or windbreak. Sie page 30 .
Norway Spruce

Pivea excrloet

Broad pramid, graceful. Rapid growing, attiains 7.5 [eet. Foliage dense, dark green. Very suecessful in cold elimates. I'sed extensively for heilges and windbreats. see page 30 .

\section{“T H E S T A N D A D OF Q UA L I T Y FOR A M ER I CA "}




\section{SPRUCE - I'ien (continued)}

Weeping Norway Spruce

Picea excelsa inverta

Foliage same as the upright Norway spruce. Habit is irregular. Branches and sometimes the leader are pendulous. Interesting dipanese effect.

Engleman's Spruce.

Picea engelmanni

Broad pyramil. Attains 100 feet. Branches densely arranged. Foliage somewhat bluish. Keeps very symmetrical without prnning. Slow grower. Useful for windbreaks. Siee page 30 .

Gregory's Dwarf Spruce.

Picca excelsa gregoryana

A very dwarf form of Norway spruce Odd and interesting, very rare. Should be seen to be appreciated. P'rices upon application.

\section{Pyramidal Norway Spruce}

Picea excelsa pyramidalis Similar to Norway spruce. Branches more upright, making slender tree.

\section{Maxwell's Dwarf Spruce}

l'icea cxcelsa maxuelli Dwarf Norway Spruce

Picca excelsa pumia

Both varieties are rare, okt, and interesting. Should be seen to be appreciaterl. P'rices upon application.

\section{Tiger-tail Spruce}

I'icea polita

Broad, dense, pyramil. Branches stont, needles stiff and sharp. How growing.

\section{†Koster's Blue Spruce}

Picea pungens kosteriana

Au improved form of the Colorado Blue spruce. Foliage is much bluer. Fine elfect when planted individually or in groups.

Colorado Green Spruce

Picea puguens Slow growing, symmetrical. Needles stiff and sharp; light green. Valuable for seashore planting or for windbreakr. See page 30.

†Colorado Blue Spruce

Picea pungens glaucu

A form of the preceding, but foliage is distinct blue. Fine specimen tree attaining 100 feet.

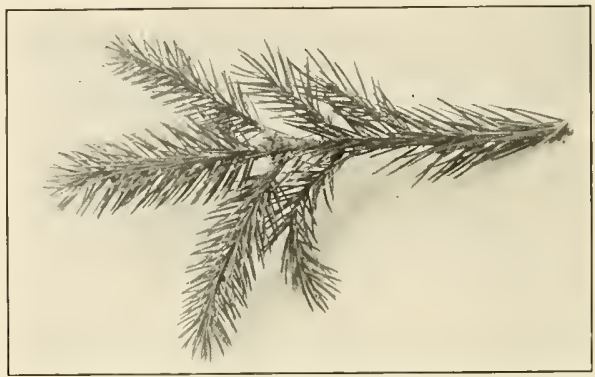

Spruce Foliage.

PINE - Pinus

†Austrian Pine

Pinus aust, iaca

Broad, pyramidal, symmetrical. Attains 100 feet. Foliage long, dark green. Vigorous grower. Thrives in any ordinary soil and location and is particularly good near the seashore.

\section{Scotch Pine}

Pinus sylvestris

Tall, rapid growing tree attaining a height of 70 feet. Foliage bluish green.

\section{† Jack Pine}

Pinus divaricata

Upriglit, somewhat irregular habit. Foliage handsome medium green. Ittains height of 70 feet. Thrives on dry and poor soils. Rapid grower. Valuable for screen plantings. Siee page Q0).

\section{tMountain Pine}

Pinus montana

Broad rounding cone. Branches upright. Needles short and very handsome. Iseful for bank plantings or in the roek garden.
tDwarf Mlountain Pine

Pinus montana mughus Low, dense, dwarf, lranches spreading, branchlets upright. Considerably broaler than tall. Dessely coverel with needles varying in color throughout for entire range of green tints and shades. Valuable for single specimens and also for bank plantings and for the rock garden. Particularly handsome. Extremely hardy. Thrives on any soil except a wet one. Arlapterl to seaslyore planting.

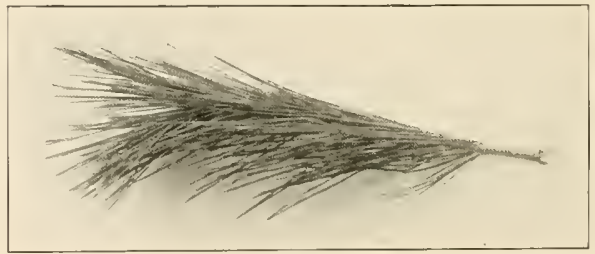

Pine Foliage.
F R A M I N G H A M
N U R S E R I E
F R A M I N G H A M,
M A S S. 


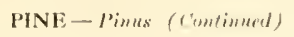

Red Pine

Pinus resinosa

Ppright, broad rounding pyramis. Attains fo fect. stems reddish. Foliage very long; light green. Very hardy and thrives on poor suil. Subject to no dangerous disease or insect encuy.

1 tree which is becoming more popular on its merits.

\section{Japanese Umbrella Pine}

Siriadopitys rerticellata

One of the most lenutiful of avereens. Medium pyramid, comprat. Necolles lemg, glossy light green, arow in whorls. Very buslyy, and thrives in any ordinary soil.

†White line

P'inus strobus

One of the lrest of our native esergreens. At tains 100

feet. Foliage long liglat silvery green. I seful as single specimens or as groves.

\section{JAPANESE CYPRESS - Retinisport}

Thread-branched Cypress

Retinispora filifera

Broad cone. Foliage bright green, slender, string-like, drooping, graceful.

\section{Golden Thread-branched Cypress}

Retinispora filifera atrea

1 golden form of the preceling. Broader and rather fat.

\section{Pea-fruited Cypress}

Retinispore pisifere Medium cone. Foliage light green, feathery, sliglatly. drooping at tips.

Golden Pea-fruited Cypress Retinispora pisifero untea I yellow form of the preeding.

\section{Plumed Cypress}

Rerinisporo plumosa

Medium eone. Foliage light green, soft, plumelike, feathery. Looks best if sheared shghtly the last of June.
Golden Plumed Cypress

fimilar to preceding. Foliage yellow, parlicoularly on the sumus sille.

\section{Veitch's Cypress}

Litinispore squarrosu veitchii

Broatl cone. Foliage bluish-gray. Very dense. lacequires shearing each June. Slould be planterl in sledteresl position and not in full sum.

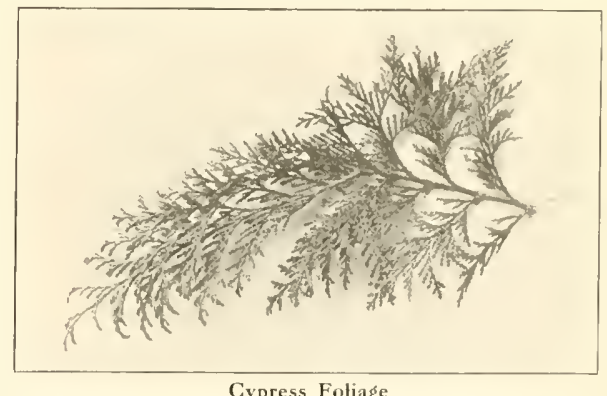

YEW - Taxus

This is a family of low, slow-growing evergreens. While the English varieties are a trifle tender here, the Ameriean and Japanese varieties are anong the litrdiest of evergreents.

\section{English Yew}

Taxus burcata

Epright in habit. Foliage rich dark green. thould be planted in sheltered positions away from the dircet glare of the sun.

Dwarf English Yew

Taxus barcata alprossa

Dwarf, round, nearly globose. Branehes small and numerous. Leaves very small. Needs shelter.
Golden English Yew

Taxus baccula unta I variety of English lew. Foliage somewhat yellow in summer, darkening in fall and winter.

Ereet American Yew

Taxus ranadensis erecta Similar to the preceding. Branclues upright, forming a vase shaped plant. Deeper winter oolor, and withstands sunny positions better than the Inerican Yow.

\section{“ T H E




$$
\text { YEW - Taxas (Contimued) }
$$

Prostrate, branches wide spreuting. Terminal branchlets long, slender and drooping. Hark brown. Foliage deep green. Branchlets die baek somewhat during winter if planterl in sunny positions, therefore, it should be planted in partial or complete shade. Red waxy berries.

Japanese Yew

Taxus cuspidata

Irregular habit sprealing to upright, sometimes fan shaperl. Slow growing, nearly globe-shaped when mature, Foliage similar to English Yew in color.

\section{Dwarf Japanese Yew}

Taxus cuspidata nana

Fxeedingly slow growing, globe-shaped when mature. When young habit is irregular, varying from fan-shaped to globe-shaped and flat round mats. The breadth is in every case somewhat greater than the height. Exceedingly hardy. Keeps its deep rich green the year round.

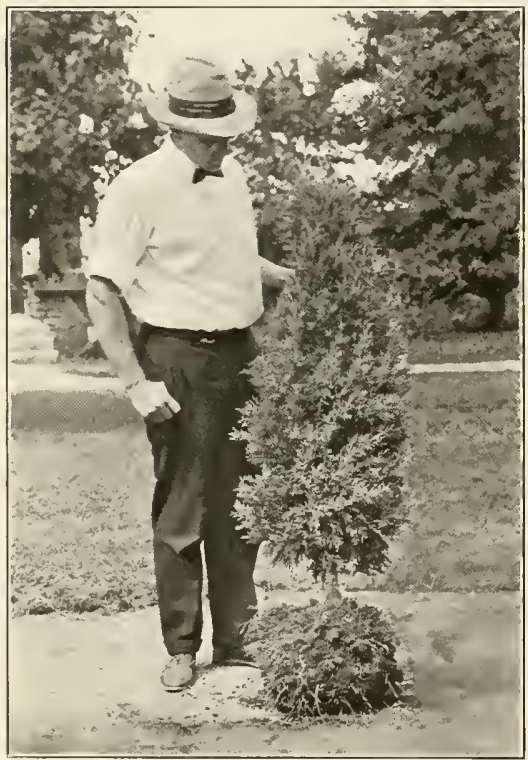

The Framingham way of preparing Evergreens for shipment. At the left, the tree dug with compaet ball of earth protecting the roots. At the right, the ball of protecting earth seeurely tied in burlap - now ready for packing in cases or on motor trucks.

F R A I I G H A M N U R S E R I S - F R A M I N G HA M, MA S S.

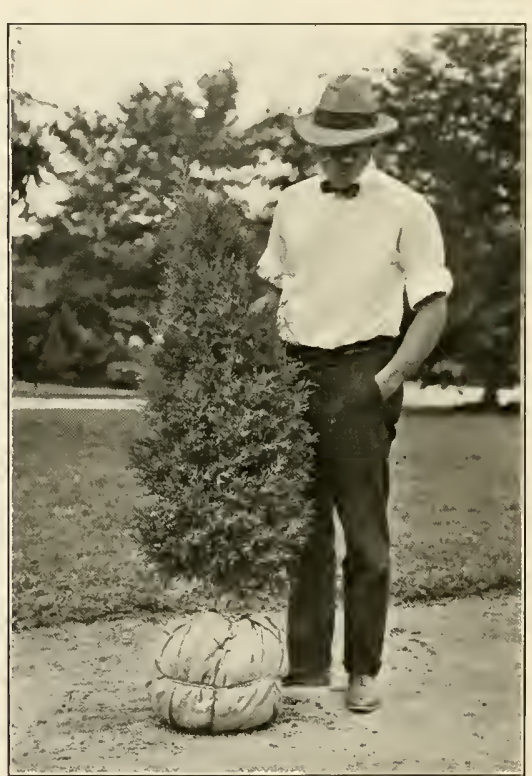

A new and distinctive variety to be found only at Framingham Nurseties. Leaves are longer than on any other lew. Exeeptionally rich glossy green. Varies in habit from broal symmetrical pyramid to dense globe, and to irregular spreading form. The hardiest of all. Persons interested should visit the nursery and select the type which suits then at which time priees will be quoted.

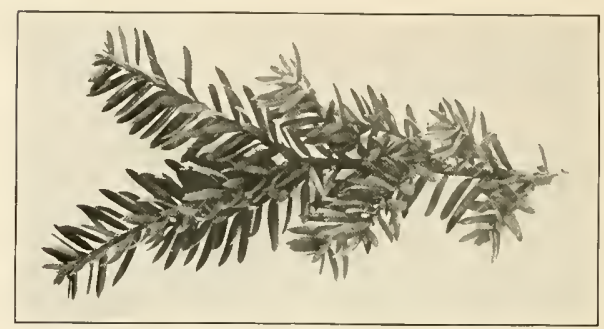

Yew Foliage 
ARBORVITAE - Thuya

American Arborvitae

Thuya ocridentalis

Narrow cone or columnar. Densely hranched. Commonly used in liedges, aml as single specimens. Thrives in moist soil and also somewhat dry soils. loes not like real wet soil.

For use as a liedge, see page $\$$ t

Peabody's Golden Arhorvitae Thuyn ocridentulis aurea Similar to the preceding; foliage is of intense yellow color.

\section{Douglas's Pyramidal Arborvitae}

Thuya occidentulis douglasii pyramidalis Narrow cone. Foliage arranged in a very interesting manner.

Ilovey's Golden Arborvitae

Thuy accidentulis hovey $i$ Oval shape, very dense, foliage tinged with golden yellow.

Vervaene's Arborvitae

Thuya occidentulis vervaencana Broad cone. Dense. Foliage variegated with yellow, giving the plant a light golden tinge. Valuable for hedges near dusty roads.

Globe Arborvitae

Thuya occidentalis globosa Low, slow growing, dense, glohe-shaped. Foliage bright green; winter color bronze. Valuable for low round hedges. For hedges of this variety see page 34
Pyramidal Arborvitue Thuya oc identa'is pyramidalis Very narrow eone or column. I hensely brancheil. Foliage rich, dark green which does not change appreetably in winter. Excellent for formal effects, and for screens. see page 29

Siberian Arborvitae

Thuya aecidentulis siberice

Broad cone. Very dense and hushy, Dark sterl grayish green. Extremely hardy on a wide range of soils. I seful for heilges. See page ist.

Oriental Arborvl tae

Thuya orientolis Narrow ene or column. Foliage bright green with reddish tinge in winter. Large plants good for formal effects.

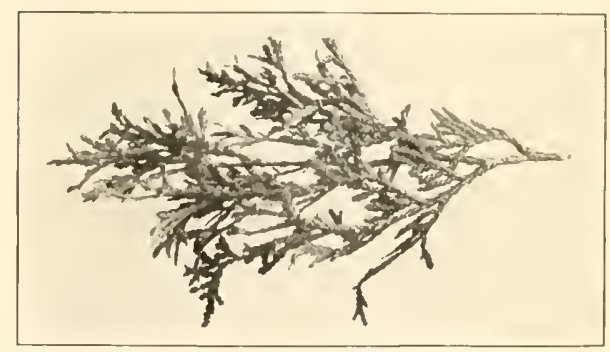

Arborvilae Foliage

\section{HEMLOCK - Tsuga}

American llemlock

Tsuga canadensis

Broadly pyramidal tree attaining 70 feet. Densely branched. Branch tips pendulous. Very beautiful and graceful. Thrives exeeptionally well in shade of larger trees. Does well almost anywhere except extremely bleak situations. Valuable both as a single specimen and as a hedge plant. See page 29.

Globe-shaped Hemlock

Similar to the precerling lint upright. Nearly perfectly globe-shaper. Very compraw

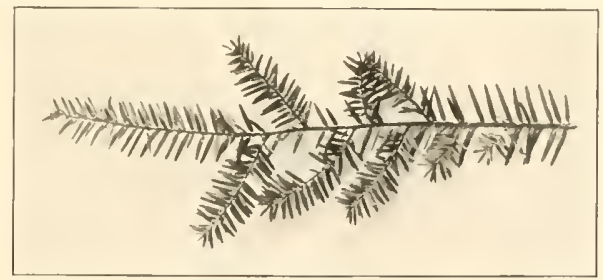

Hemloek Foliage

Owing to seasonal fluctuations in the prices of nursery stock we have discontinued the practice of inserting prices in this general deseriptive eatalog. The information in this book holds good over a long period and for this reason we recommend its preservation. Seasonal price lists will be mailed you twice a year March Ist and September Ist. If however you do not receive them please notify us.

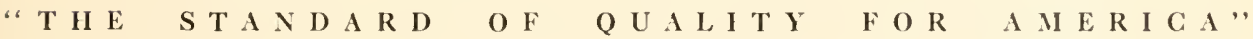




\section{BROAD LEAVED EVERGREENS}

A sub-gromp of evergreens, with leaves approaching in size and shape the leaves of deciduous shrubs. The habit is in most cases similar to that of deciduous shrubs. Many varieties have strikingly beautiful flowers.

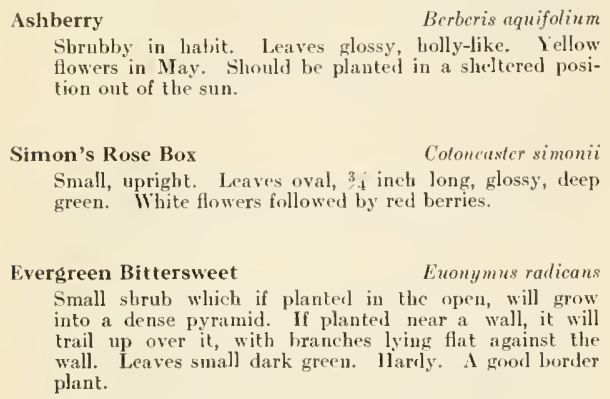

Simon's Rose Box

Colonerester simonii

Small, upright. Leaves oval, ${ }^{3}$ ineh long, glossy, deep green. White flowers followed by red berries.

Evergreen Bittersweet

Exonymns radicans Small shrub which if planterl in the open, will grow into a dense pyramid. If planted near a wall, it will trail up over it, with branches lying flat against the wall. Leaves small dark green. llarrly. A goorl border plant.

\section{Large-leaved Evergreen Bittersweet}

$$
\text { Euonymus radicans grandifolia }
$$

Sinilar to the preceding. Leaves large, oval. Will make a dense round bush, or wil] trail up walls making a very busby covering. Rapid growing. A good hedge plant. Red and orange fruit.

\section{Variegated Evergreen Bittersweet}

Euonymus radicans variegata

The same as Evergreen Bittersweet excepting that its leaves are variegated with yellow, white, and pinkish tints.
Broad-leaved Evergreen Bittersweet

Eumnyms radicans vegeta Low, spreading, trailing, slow growing. Leaves nearly circular, dark. Bears a large quantity of showy red and orange fruit. Will trail slowly up walls.

Prostrate Rose Box

Cotoneaster horizontalis Low spreading shrub with almost horizontal branches. Leaves less than a balf inch long, round, dark green. Flowers pinkish white followed by searlet berries. If planted against a rock or wall, it will trail up over it.

Sheeps Liarel

Kolmia angustifolia small shrub. Leaves $1 \frac{1}{2}$ inches long, narrow, light green on top, pale underneath. Covered in late June and July witls purple and erimson elusters of flowers.

Monntain Laurel

Kalmia latifolia Shrub with large, glossy leaves. Covered with large dusters of white flowers tinged with pink in middle June. Ilardy. Thrives in ordinary soil. Prefers partial sliade.

Drooping Andromeda Loucothoe catesbaei Small uprigbt sbrub with arehing branches. Desirable for both foliage and flower. Leaves heavy, glossy green in summer, ehanging to purplish red during winter. Flowers creamy white and abundant. Yery bardy and desirable.

lily-of-the-Valley Shrub

Pieris floribunda Round, compact, dwarf. Blooms in early Spring, bearing flowers resembling Lily-of-the-Valley.

\section{RHODODENDRONS}

Not in limed snil

Rhododendrons are the most beautiful of all plants. Their deep green leaves, often glossy, are very striking. Rhododendrons grow broad, bushy and dense, making large rounding clumps when mature. 'The flowers range through many colors and are often very large.

Rhododendrons will thrive in any soil that will grow good vegetables, but will not grow on a lime soil. Although they like plenty of water they should not be planted where surface water eollects. 'They do best when planted in partial shade such as on the north side of buildings and mader trees. For the first two or three years they should be protected in winter by sticking pine boughs in the ground and slanting the boughs over the plants or by making a frame around them and covering the top and siles of the frame with burlap. Mulching the ground is beneficial. Pinch off all flowers as soon as they begin to wilt to insure next season's bloom. 


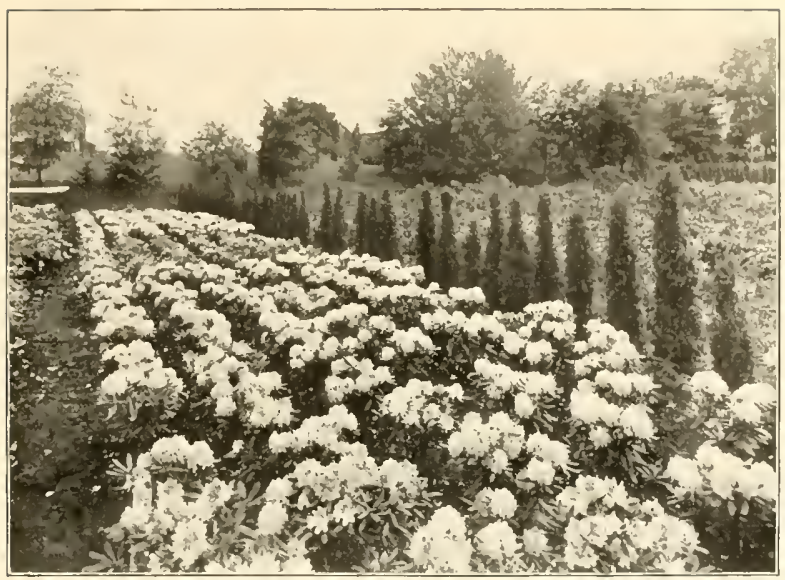

Rhododendrons in bloom at the Framingham Nurseries

\section{RHODODENDRONS}

Carolina R hododendron

Rhodolendron carolinianum

One of the most beautiful and hardy broad-leaved evergreens. Compact in growth, attains height of four to six feet. Dark green leaves slightly bronzed in winter. Hlowers vary from pale to deep pink and are very numerous. Is not particular as to soil and situation.

\section{Catawban Rhododendron}

Rhododendron catawliense

The parent species of most of our Hybrid Rhododendrons. Native, very hardy. Thrives in wet or alry soil, in sunny or shady positions. Needs no protection. Leaves large, dark. Large round clusters of flowers of various tints of pinkish purple to lilac purple in early June.

\section{Adam's Needle}

Yucca filamentosa

Low plant never over two feet high. Made up of bunches of leaves is to 24 inches long, I to 2 inches wide, pointed. Bears large white flowers on a three-foot stem in late June and early July. Tropical appearance, but very hardy. llybrid Rhododendrons Rhododendron catawtiense hydribum These plants are similar in habit to Catawhan Rhododendron. Leaves vary in a minor way, These hybrids prefer is fairly rich, well drained soil. They need a lot of water during dry spells, but do not flourish where surface water atcumulates. Flowers are large, generally 4 to 6 inches across, and are of many colors. These plants should be ordered by the color of blossom desired. The following is a list of the colors we have in stock.

$\begin{array}{ll}\text { White } & \text { Pale lavender } \\ \text { Blnsh white } & \text { Deep lavender } \\ \text { Pink } & \text { Purple } \\ \text { Magenta Pink } & \text { Red }\end{array}$

Great Laurel Rhododendron maximum Largest growing ol all Rhododendrons. Very large leaves. In July bears medium sized clnsters of pinkish white flowers. Very hardy. Withstands the sun, but takes on better leal color in partial shade.

We are very careful that our Evergreens (as with all our stock) are packed and shipped in such way as to arrive in perleet condition. No plant that hasn't a thick, heavy mass of vigorous rootlets, ready to eatch hold and work, is allowed to leave the nursery. 
Whether trees, shrubs, evergreens, or vines, Framingham Nursery stock has the beauty, hardiness, and vitality so neessary to sueeessful planting in this severe northern elimate. Every plant is thoroughly aeelimated before being sent out. Our soil is perfeet and our growing methods correct. We are very eareful that our stoek is packed and shipped in sueh way as to arrive in perfect condition. No plant that hasn't a thick, heavy mass of vigorous rootlets, ready to cateh hold and work, is allowed to leave the nursery.

Except where noted to the eontrary, all stock listed in this catalog will thrive well in ordinary garden soil. See that soil is at least eighteen inehes in depth. Ifter hed is laid out, spade up and well pulverize. Soil for Evergreens should contain decayed vegetal, matter, leaf mold, ete. Presence of this humus improves the color of plant. It ean be olstained in any woods nearby. Mix it well with the soil. Or old rotten manure will serve the purpose. Manure should be used very carefully however. It ean be used in the soil in two ways: - (1) by burying a layer two or three inehes below point that roots set to. (I) by putting it on top and gradually raking it in. Never allow it to touch any part of the plant roots, stem or branches. If used, take care that it is well rotted. Green, it has a burning effect.

Quite the most important point to be observed in all plantings is to make sure that, after the soil has been well broken up, it is mixed through the root system and well packed in around the roots so that no air holes remain to dry out the roots. It is always well to dig hole considerably larger than is actually required and throw back enough soil to make it about the size necessary for the roots. This makes sure that the surrounding earth is pulverized, and allows the roots to penetrate readily. It makes a great differenee in the successful growth of the plant. After plant is set in hole, tread the earth in with foot or poke it in around the roots with a stick.

\section{Deciduous Shrubs}

These have spreading roots. Shake and spread them out well. Place plant in hole so that top earth is about even with the surface mark (plainly visible, where the top of the ground has been previous to transplanting), putting in soil shovelful at a time and packing in well as above. Use water as directed for "Trees".
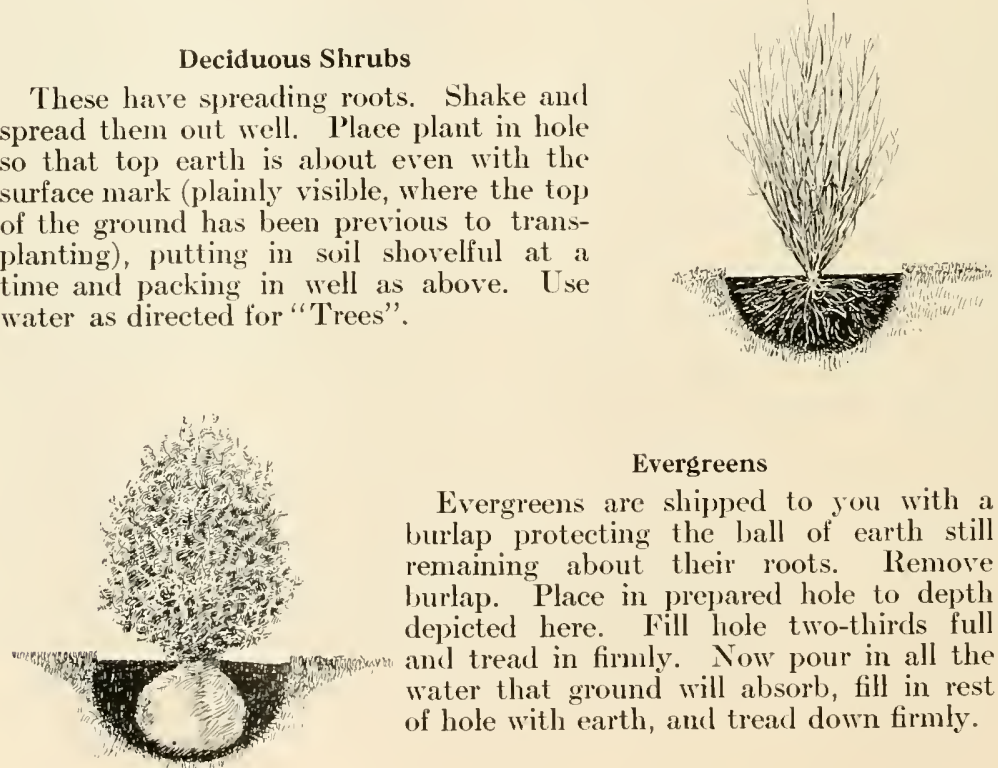

Evergreens

Evergreens are shipped to you with a burlap protecting the ball of earth still remaining about their roots. Remove burlap. Place in prepared hole to depth depicted here. Fill hole two-thirds full and tread in firmly. Now pour in all the water that ground will absorb, fill in rest of hole with earth, and tread down fimly. 
Where the soil is gravelly, it is practically necessiary 10 dig an esprecially latrge hole and fill in with lo:m an in sketch.

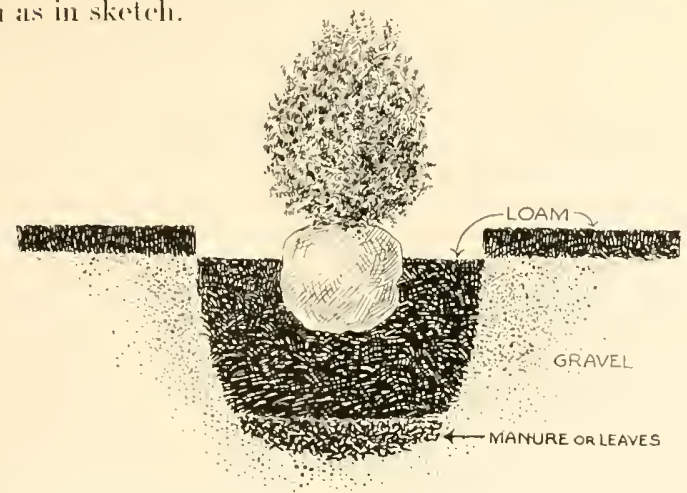

A lityer of wedl-rotted manure or rotted leaves at the botton will help hold moisture. The new loam should he trampled down well before setting the plant.

Whether deciduous or evergreen, do not pour water on top of soil around plant inmediately after planting. Wait a day or so before watering again. Niter plant has "taken hold" however, it is very important that it be kept well watered. This does not nean simply" sprinkling it. Pour the water around the roots in liberal quantities and often. Scant sprinkling is often worse than no water at all.

\section{Trees}

Place in hole so that the old surface mark is buried an inch or two, no more. Throw in earth, taking care to tread it and poke it in around and under the roots while this is being done. When two-thirds full turn hose into hole and give it all the water it will absorb. Fill in rest of hole and tread firmly. If necessary, rope the tree to stakes (as here) to keep it from blowing. Be sure to protect its birk with hurlap so that rope will not chale and damage it.

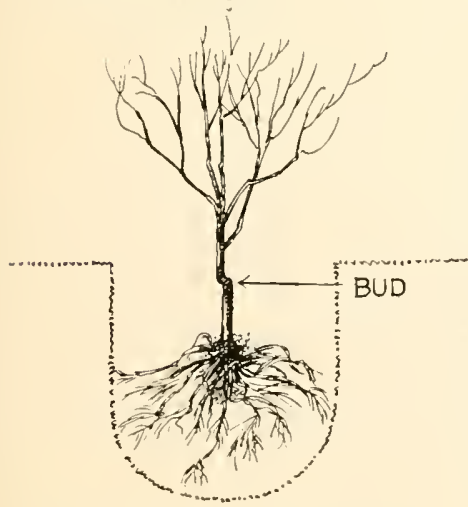

\section{Roses}

On hylorid roses thiat have been "budded" be sure to bury the "hud" allout two inches. Other than hybrit roses, or those grown on their own roots, should be buried just a little deeper than the earth marks on their stems, indicating where they were buried before being transplanted.

\section{“T H E S T A N D A R D}

O F $\quad$ Q U A L I T Y

F O R

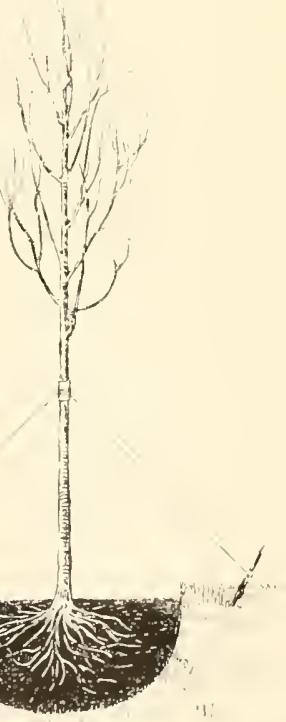


It is an easy matter to determine whether a rose has been "budded" or grown on its own roots. Those grown on own roots look something like this
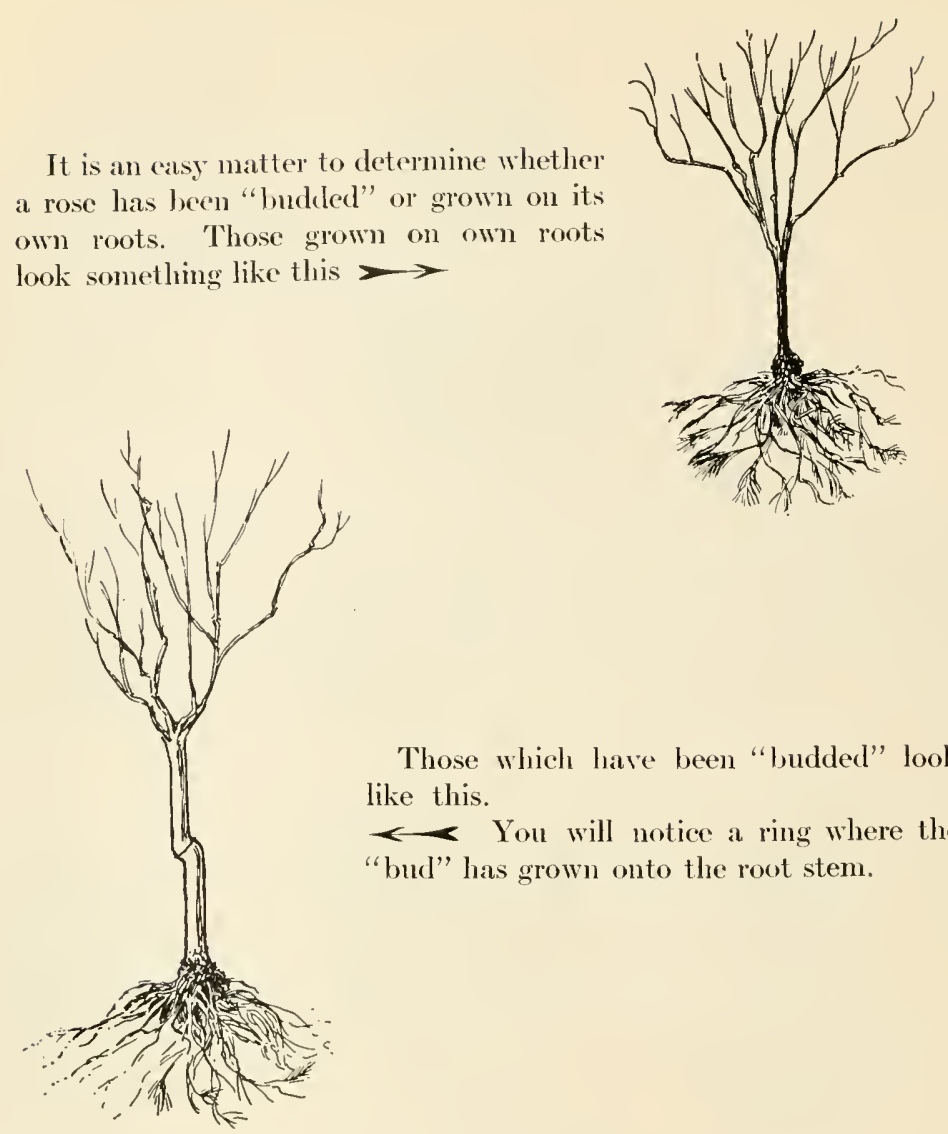

Those which have been "budded" look like this.

$\longleftrightarrow$ You will notice a ring where the "bud" has grown onto the root stem.

\section{PROPER PLANTING SEASONS}

Framingham Nursery stock, both of evergreen and deciduous variety, may be successfully transplanted in the Spring, from the time that the frost is out of the ground (which in New England usually averages about April first) until the buds burst, late in May.

In the Fall, evergreens should be set out from the first of August until early November. Deciduous trees and shruls may be planted for a Fall period beginning the latter part of Scptember and contimuing until the ground freezes. The extent of this Fall planting season depends largely upon climatic conditions; as, of eourse, frost comes and the winter sets in much earlier in some sections than in others.

F R A M I G H A M N URSERIES-FR A M I NGHAM, MAS S. 


\section{Framingham Nursery Delivery Service}

Framingham Nursery stock may be delivered in three ways: - l,y freight, express, or motor truck. Owing to the congested condition of transportation facilities so prevalent during recent montlss, and which may well be predieted to continue for an uncertatin periosl, enstomers will find our molor truck service the most completely satisfinctory of the three methods. Our own trucks make delivery anywhere within a raclius of sixty miles of lianningham. This serviee costs lut lithle more than freight, is tess expensive than express, and mueh more speedy and dependable than either. Another point which finors those who make

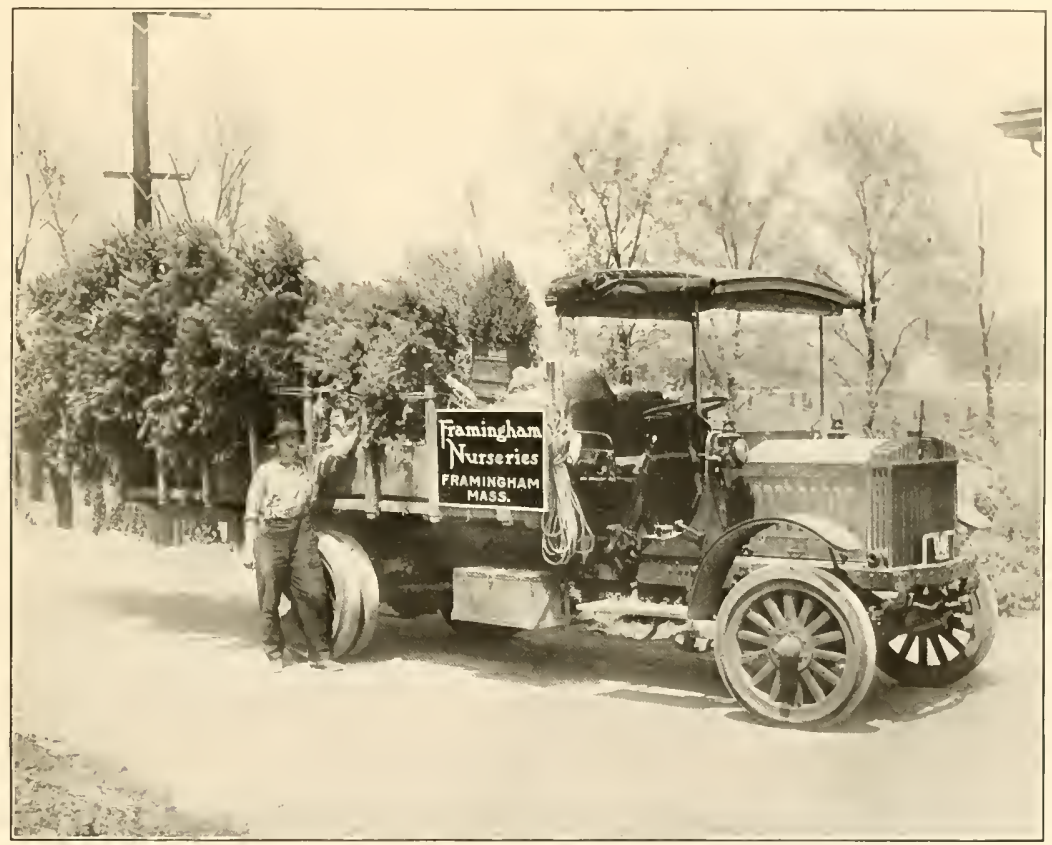

use of this service comes in the fact that when stock is shipped by freight or express, our responsibility as to it, fresh and perfect condition must naturally cease upon delisery to the transportation companies. While, when delivered direet ly motor truck, our responsibility does not end unt il the stoek is detivered on your grounds.

In ordering, please be sure to specify which of these three methods you wish used in making delivery - freight, express, or motor truck. 


\section{Index}

Birds (Key to) ( - : t t t t

Climbing l'lants $\$ 1$

leciduous shrubs for foundation llanting $\quad$ i-11

Deciduous Shrubs for Natural Plantings . . $44-46$

Decidusus Shrubs, lledges . . . . . . . . 32-34

Deciduous Shrubs (Ilow to Plant). . . . . . 58

Deciduous Shrubs for treens and Border Planting 26-28

Deciduons Trees for screen purposes . . .

Deciduous Trees for shade purposes $37-39$

Delivery service. . . . . . 61

Description of all Evergreens. . $\quad 50-57$

Evergreens for Foundation Planting . $12-19$

Evergreens for screen l'lanting $\quad 29$

Evergreens for Hedges. . . . 34

Evergreens (description of all) $\quad 50-57$

Evergreens (How to Plant) . 5

Evergreens (for Wind Breaks).

Foundation Planting . . . . 4-19

General Purposes of Planting .

Ground Covers for Shady Places $\quad+7$

lledges . . . . P

llow and When to Plant $\quad 58-60$

Individual Specimens $\quad$ \$1-42

$\begin{array}{lr}\text { Mechanical side of Planting } & 58-60\end{array}$

Natural Plantings _. $\quad \$ 4-\$ 6$

Odd Purposes (Plants for) $\quad 47$

Plants to Attract Birds $\quad$ 43-4t

Piazza and Pergola Plantings. . . . . to- $\$ 1$

Plantings to cover Masonry or Brick Walls 47

Plantings to prevent soil Washing $\quad 47$

Plantings for Seclusion and Privacy _ . $29-25$

Planting Seasons _ _ . . . . $\quad 60$

Protective Plantings . 32

Roses. . . . . . 4 S- 49

Roses (Climbing) . 41

Roses (1low to Plant) 59-60

Screen Planting. $\quad 200-29$

Seasons for P'lanting . $\quad 60$

sharle Planting . . . . 35-39

Shady. Places (Ground Covers for)

Trees (Jlow to Plant) _ _ _ _ _ _ _ _ n

Trees for Natural Plantings _ _ _ _ $\quad 46$

Trees for Screen purposes . . . . . 98

Trees for shading . . . . . . . . 37-39

Trees (for Wind Breaks) . . . 31

Vines and other Climbing Plants. +1

Wind Breaks. . . . . . . . . 30-31 


\section{To the Reader}

W E ask your indulgence for again ealling attention to the essential ineompleteness of the material contained in the foregoing parges. Our book is in no way intended as a technieal work of reference. It has been compiled along such radically new and different ideas of elassification and presentation from those followed in the usual Plant Catakg, that - thus loeing what we belicre to be the first of its kind, and having been ereated upon no pattern or gniding precedent other than our own ideas and ideals of what would he most genuinely helpful- it is only a natmal conseguence if the result as here presented falls short of that perfection of eompleteness which we hope to develop from year to year in future editions. If it simply serves to carry a practical suggestion or two for the further beaulification and comfortizing of your home and its surroundings, and at the same time facilitates the putting of such suggested improvements into effect, its mission will have been fulfilled. Should you at any time, however, desire more detailed information on any of the subjects touched upon here, please let us know. Many a persm neglects setting out necessary shrubs and trees beenuse selection and planting seem a difficult task. Let us help you over any such possible uncertainties and dolays. We are always, and gladly, at the service of the lomebeautifier who wishes to obtain the most thoroughy suitable plants for each specific need, together with the very hest results from every expenditure made.

\section{Framingham Nurseries





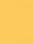

4

$$
\checkmark
$$
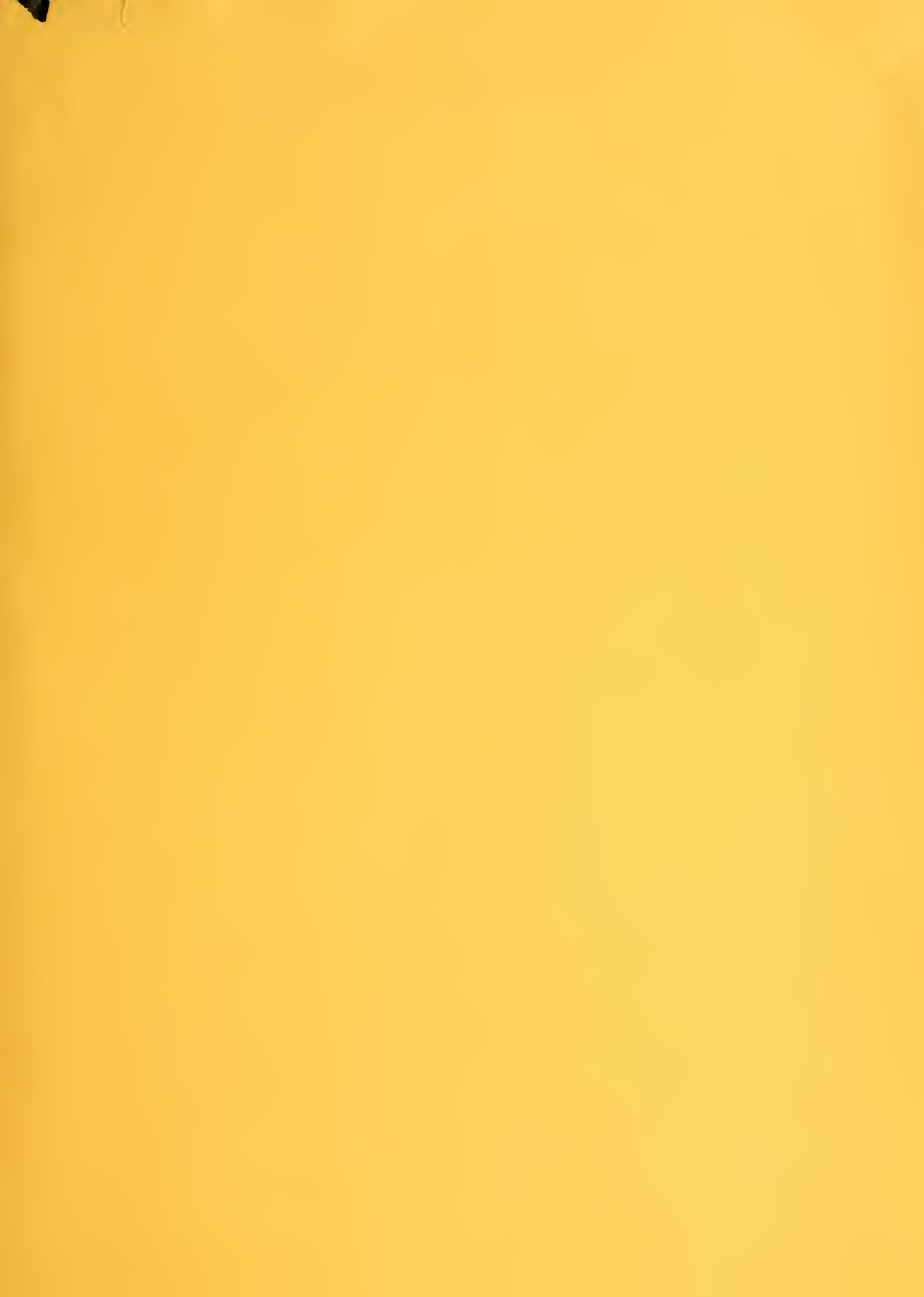

要

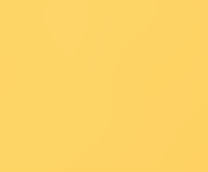


